\title{
ワニのエナメル質形成時におけるエナメル芽細胞の 微細構造に関する電子顕微鏡的観察
}

\author{
山 下 靖 雄 \\ 東京医科歯科大学歯学部 第一口腔解剖学教室 (指導 : 一条 尚教授)* \\ [受付 : 昭和51年 3 月 31 日]
}

抄録: 爬虫類は, 魚類や両生類から哺乳類への移行として, 系統発生学的に重要な 位置づけがなされてい る。したがって, 歯の形成機構を究明するための比較発生学的研究の一端として, 爬虫類のワニを材料とし, 内エナメル上皮の初期段階から，エナメル質基質形成期末期にいたるエナメル芽細胞の形態と 構造に関する 時期的な推移について, 透過電子顕微鏡を用いて観察をおこなった。

内エナメル上皮は，エナメル芽細胞に分化をおこすにしたがって伸長するが，ワニでは細胞の伸長が緩慢 で, 象牙質基質形成の後期に, 核と Golgi の移動が行なわれ, さらにエナメル質基質の形成がやや進行した 後に, 細胞長が最大となる。

芽細胞が分化をおこす過程や形態と構造の推移に関しては，魚類とは多少異なる点もあり，基本的に哺乳 類のそれと類似し, 中胚葉エナメル質の魚類から哺乳類への移行を示している。

\section{緒言}

爬虫類の歯に関しては,すでに1765年 Fontana ${ }^{11}$ がオウシュウクサリヘビ（Viper）の毒牙の 構造 形態について記載している。さらに1840年 Owen ${ }^{21}$ が王蛇 (Boa), ニシキへビ (Python), Viper, Iguana, Chameleon, ワニ (Crocodile) などの歯 の形態について観察するとともに，はじめて組織 学的に 観察を行なっている。その後, Tomes $\left(1876^{3)}\right.$, 19234), Woerdeman $(1921)^{5)}$, Bolk $\left(1922^{6)}, 1923^{7)}\right)$ などをはじめ，多数の研究者が 種々の爬虫類の歯について観察を行なっている。

しかし爬虫類の歯に関する従来の観察は，毒牙 を主とする構造形態ならびに組織学的観察が多 ${ }^{5,6)}$, 発生学的研究は比較的少ない。

またこれらの中で，古い時代の研究者によるエ ナメル質に関する観察では，エナメル質の存否に ついてのみ記載をおこなっているものがほとんど で, Owen ${ }^{2)}$, Leydig $(1873)^{8)}$, その他 ${ }^{9,10)}$ はそれぞ
れ観察を行なった材料では，エナメル質が存在し ないといい，これに反し Tomes $\left(1876^{3)}, 1923^{4)}\right)$ らはエナメル質の存在を認めている ${ }^{11-13)}$ 。なお最 近の研究では, Poole (1957 $\left.7^{14)}, 1967^{15)}\right)$, Kvam $\left(1958 b^{16)}\right)$, Bellairs $(1969)^{17)}$, Peyer $(1968)^{18)}$ どによってワニやトカゲなどの歯について光顕的 に観察がなされており，これらについてはすべて エナメル質の存在が記載されている。

さらに毒牙のエナメル質の構造に関しては，高 橋 $(1941)^{13)}$ がエナメル質外表に平行な $2 \sim 3$ 条の 黒線が認められるという非常に簡単な記載がある のみである。

また発生学的研究に関しては, Tomes $(1876)^{3)}$ $ら^{11,19)}$ が毒牙の形態についてごく簡単に記載をお こなっているほか, ヘビの毒牙に関し， Röse $(1894)^{111}$ その他は，䪽中に発育する後続の歯胚群 や歯堤について観察を行なっているが, これ らは発生の早期に重点をおいた簡単な観察が多

Electron microscopic studies on the ultrastructure of ameloblasts during amelogenesis in Caiman Crocodilus.

Yasuo Yamashita (1st Depertment of Oral Anatomy, School of Dentistry, Tokyo Medical and Dental University, Tokyo)

* 東京都文京区湯島 1-5-45（干 113） Jap. J. oral Biol., 18 : 188-238, 1976. 
$W^{9,11,12,19-21)}$

しかし近年, 頼(1972) ${ }^{22)}$ はマムシを材料として, 毒牙に関する歯堤および歯胚の 形成過程ならびに 両者の関連性，さらには毒牙の形態形成について 詳細な観察をおこなっている。

さらにへビの毒牙以外では，ワニを材料として， Mummery $(1924)^{23)}$, Edmund $\left(1960^{24)}, 1969^{25)}\right)$, Poole $(1961)^{26)}$, Peyer (1968) ${ }^{18)}$ らが歯の交換様式 について簡単な観察をおこなっている。

哺乳類のエナメル質形成が外胚葉性由来である ことは，すでに古くから定説となっている。また 魚類, 両生類, 爬虫類などの各種動物におけるエナ メル質形成に関する発生学的研究では, Tomes ${ }^{3,27}$ などの古い時代から今日までその発生由来が最も 問題となっており，それらに関しては非常に多く の研究者によって各種動物で種々の見解が報告さ れている。

Kvam (1946 1960) ${ }^{16,28-34)}$ は魚類や 両生類なら びに爬虫類などの歯について光学顕微鏡的観察を なし，魚類から両生類までのエナメル質はすべて 中胚葉由来であるとし，爬虫類になってはじめて 外胚葉性のエナメル質になると記載している。

しかし魚類に関して，脇田 $(1974)^{35)}$ と小野 $(1974)^{36)}$ は，魚類のエナメル質形成にともなうェ ナメル芽細胞の時期的な推移について，電子顕微 鏡を用いて観察し，魚類ではエナメル質の基質が 中胚葉由来であるが，上皮性のエナメル芽細胞の 積極的な関与のもとにエナメル質が形成されるこ とをみとめている。

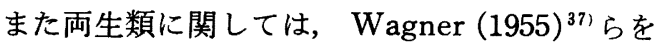
はじめ幾人かの研究者によってェナメル質が外胚 葉性由来であることが認められ ${ }^{18,38-41) ， と く に 川 ~}$ 崎 $(1971)^{42}$ はイモリの各発育段階の 歯胚をおって 歯の各構成要素について発生学的観察をおこな い，イモリのエナメル質は外胚葉性であることを 認めている。

また，爬虫類に関しては $\operatorname{Kvam}\left(1958 b^{16)}, 1958\right.$ $\left.\mathrm{a}^{31)}, 1959^{32 \prime}\right)$ のワニにおける所見のほか, Poole $\left(1957^{14)}, 1967^{15)}\right)$, Bellairs (1969) ${ }^{17)}$, Peyer 1968) ${ }^{18)}$, Edmund (1969) ${ }^{25)}$ らはワニやトカゲな どの歯で観察し，ともにエナメル質は外胚葉由来 であることが認められている。
しかしながら爬虫類のエナメル質形成に関する 従来の観察は，いずれも断片的で，簡単な観察に とどまっているものがほとんどであり，しかもす べてが光顕的に観察されたものであって，爬虫類 に関してはエナメル質形成をはじめ，歯の形成に 関する電顕的観察はみられない。そのため爬虫類 のエナメル質形成に関しては 今なお不明な点が多 い現状である。

そこで著者は，従来観察を行なってきたワニそ の他の歯の形成に関する所見 ${ }^{43-53)}$ をとに，歯の 形成機構を究明するため, 比較発生学的研究の一 端として，本研究ではワニにおける内エナメル上 皮の初期状態から，エナメル質基質形成が完了す るまでのエナメル質基質形成にともなうエナメル 芽細胞の形態と微細構造の推移変化について，主 として透過型電子顕微鏡を用いて観察をおこなっ た。

\section{材料と研究方法}

爬虫類のワニ（メガネカイマン Caiman Crocodilus, 体長 $90 \mathrm{~cm} \sim 130 \mathrm{~cm}$ ) を材料とし, 上下頡 における各発育段階の歯胚を摘出したのち，直ち

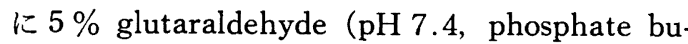
ffer, $\left.4^{\circ} \mathrm{C}\right)$ で 3 時間前固定を行った。その後 Stocksolution ( $\mathrm{pH} 7.4,0.1 \mathrm{M}$ phosphate buffer + $0.22 \mathrm{M}$ sucrose, $\left.4^{\circ} \mathrm{C}\right)$ に入れ約 3 時間放置し, さ らに $2 \% \mathrm{OsO}_{4}\left(\mathrm{pH} 7.4\right.$, phosphate buffer $\left.4^{\circ} \mathrm{C}\right)$ で 3 時間固定を行なった。その後常法に従って脱 水し, Epon 812 (Luft 1961) で包埋をおこない, ガラスナイフおよびダイヤモンドナイフを用い て, Porter-Blum MT-2B 型ミクロトームで超薄 切切片を作製し，電子顕微鏡的観察を行なった。 なお，超薄切切片作製に先だち， Epon 包埋切片 に0.5\% toluidin blue ( $\mathrm{pH} 7.4$, phosphate buffer) 染色をほどこし，光学顕微鏡的観察を行った。

電子顕微鏡による観察に用いた切片は uranyl acetate (Watson 法) おょび lead hydroxide (Reynolds 法) の二重染色を行ない，日立 HS-7 $\mathrm{S}$ 型および日立 $12 \mathrm{~A}$ 型電子顕微鏡を用いて観察を 行った。

観 察 所見

\section{A. 光学顕微鏡的所見}




\section{1. エナメル質基質形成前の 内エナメル上皮}

象牙質基質形成前の内エナメル上皮は，全般的 に細胞の背丈が 低く中胚葉領域との境をなす basement membrane に接している。内エナメル 上皮の初期状態では，細胞形態が不規則で，核も 細胞の形態に対応して不規則なものが多い（図 1)。また，核の存在位置も細胞によってまちま ちで一定していない。この時期では，象牙芽細胞 も未分化である。一方, 歯胚の上皮性要素は内外 エナメル上皮とエナメル髄からなり，初期状態の 内エナメル上皮に対応する 領域のエナメル髄で胞 は，細胞が突起をもって結合しているがまだ細 間隙が比較的少ない。

象牙質基質が形成され始める時期に近つくにつ れ，内エナメル上皮は背丈がわずかに伸長し，短 円柱形となり，細胞の形態も順次ととのってく る。それにともなって核は次第に細胞の中央付近 に位置するものが増加を示してくる(図 1)。

象牙質基質形成が開始されると，細胞形態がさ らにととのい，細胞長もやや伸長し，それにとも ない核は楕円形ないし卵円形をなすものが多く， 細胞の中央ないし中央よりやや基底側に位置する ようになる。この時期の象牙芽細胞は, 次第に成 長分化を起こし，またエナメル髄が拡大されると ともにエナメル髄の細胞は 細長い多数の突起で互 いに連絡結合し， 細胞間隙の増大にともなって, 全体としていわゆる網状を呈するようになる。し かし，ワニのエナメル髄には，哺乳類などにみら れるような明瞭な中間層は観察されず，わずかに 内エナメル上皮の基底端に近、領域のエナメル髄 の細胞が，内エナメル上皮の層にそってやや密に 配列しているのが観察される程度である。

象牙質基質の形成がさらにすすみ，象牙質の石 灰化が近づくにつれて，細胞はわずかながら伸長 し，核は順次細胞の基底側に移動する。それにと もなって核の機能側領域はトルイジンブルーで濃 染する顆粒状構造物が出現し始め，順次その数が 増加を示す。

さらに象牙質基質の石灰化が 始まる直前から， 象牙質の石灰化が 開始される時期における内エナ メル上皮では，細胞の伸長にともない核が一時細 胞の最も基底端に位置するようになる(図 2 )。
象牙質基質形成がある程度進行すると，基質の 表層側約 $1 / 6 \sim 1 / 8$ の領域から石灰化が始まり（図 2 のA点)，象牙質の石灰化はさらに象牙質表面 と歯髄側の 2 方向に向かって進行していく。

\section{2. エナメル質基質形成期のエナメル芽細胞}

象牙質の 石灰化が 表層に 向かって次第に 進行 し，やがて象牙質の石灰化が象牙質基質の表面に 達すると，それと同時にエナメル質基質が形成さ れ始める。エナメル質基質の形成面は比較的平滑 で，形成されたエナメル質基質はトルイジンブル 一で濃染する(図 2 )。エナメル質基質形成が始ま ると内エナメル上皮は細胞がさらに伸長し，核は ほぼ卵円形から楕円形を呈しているものが多く， それらが細胞の基底側に位置している。また，エ ナメル質の基質形成開始期の細胞では，核の機能 側細胞質にトルイジンブルーに濃染する顆粒が著 しく増加を示すとともに広範囲に観察されるよう になる。

エナメル質基質形成が進行し，幼若なエナメル 質基質がある程度の厚さに達すると, それ以後, 幼若なエナメル質基質の哚層では，石灰化が進行 するために順次硬度が増し，それにともなってト ルイジンブルーなどの色素に対する親和性が低下 してくる。したがってそれ以後のエナメル質基質 形成期では，色素に濃染する幼若なエナメル質基 質がつねに同じ幅を示して観察され，これより深 層では石灰化の進行によって順次硬度を増すとと もに，色素に対する親和性が減少している(図 3)。 エナメル質基質形成の初期では，エナメル芽細 胞は引続き徐々に細胞長が伸長する。しかし，エ ナメル質基質形成がある程度進行するとエナメル 芽細胞の伸長発育が中止され，細胞長が最大とな る。以後エナメル質基質形成期を通じて細胞長の 変化はみられない(図 4)。また, エナメル質基質 形成期では，細胞長が徐々に伸長するにともなっ て，Golgi area は光顕的に不明瞭であるが，核よ り機能側細胞質で占める範囲が拡大される。また 機能端の細胞質はエナメル質基質の形成が進行す るにつれて明調な部分が 出現し順次著明となる。 これらの部分は, 後述の電顕的観察所見と対比す ると, mitochondria が密に集積している領域に相 当するものである。さらに機能端のエナメル質基 
質に面する細胞膜は エナメル質基質形成期を通じ て比較的平滑で 哺乳類等で観察されるいわゆるト ームスの突起は出現しない。

また，エナメル質基質形成期に対応するエナメ ル髄は，象牙質基質形成期のそれと基本的には変 化がみられず，エナメル髄の細胞がやや扁平とな り，それらの突起によって隣接のものと結合し網 状に配列している。なお中間層は形成されない。

\section{B. 電子顯微鏡的所見}

光学顕微鏡的所見に基ゔき，硬組織形成にとも なう各発育段階のエナメル来細胞（内エナメル上 皮)について，下記のごとく I VIIの stage（略図 1 )に分けて電子顕微鏡的観察が行なわれた。 stage

I. 象牙質基質形成前の内エナメル上皮

II. 象牙質基質形成初期の内エナメル上皮

III. 象牙質基質形成後期の内エナメル上皮

IV. 象牙質石灰化期の内エナメル上皮

V. エナメル質基質形成初期のエナメル芽細胞

VI. エナメル質基質形成期のエナメル芽細胞

VII. エナメル質基質形成末期のエナメル芽細胞

1. 象牙質基質形成前の内エナメル上皮

略図 1 の Stage I は象牙質基質形成前の状態を 示したものである。

発育初期の内エナメル上皮は，まだ細胞の背丈 も低くやや不規則な形態をなし，核も細胞形態に ともなって不規則な形のものが多く，その存在位 置も細胞によってまちまちである。

初期状態の細胞では，隣接のものと互いに近接 しているが，細胞隣接面における desmosome は 発達が悪く，その数も少ない。また初期状態の細 胞には tight junctionはみとめられない。

初期状態の内エナメル上皮細胞では，細胞質に おける rER や mitochondria あるいは Golgi complex などの細胞小器官はいずれも非常に発達 が悪く, lysosome などの 顆粒状構造物もごくま れに観察される程度で，ほとんどみとめられない のが普通である。

しかし，初期状態から発育が進み，象牙質の基 質形成期に近つくにつれて，内エナメル上皮の背 丈はわずかに伸長し，短円柱形となり，細胞の形

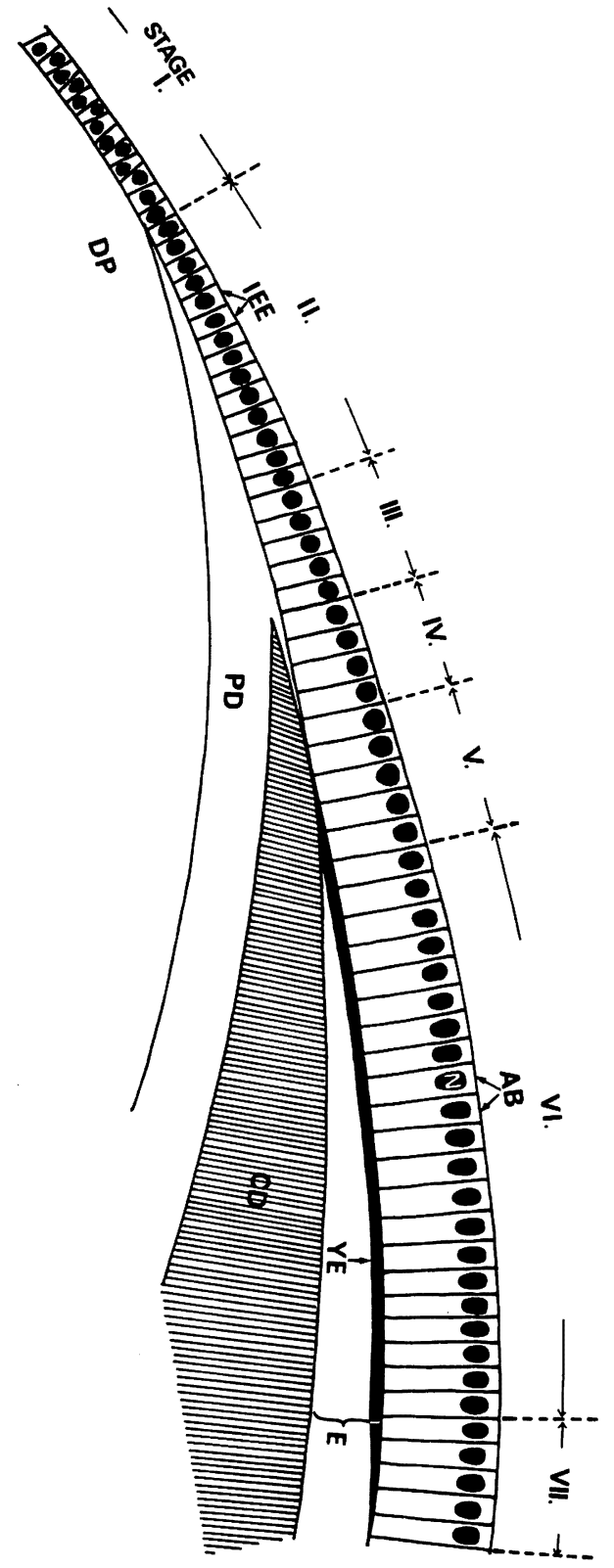

略図 1 硬組織形成とエナメル芽細胞の形態推移 Stage I : 象牙質基質形成前, Stage II : 象牙 質基質形成初期, Stage III : 象牙質基質形成後 期, Stage IV : 象牙質石灰化期, Stage V : 工 ナメル質基質形成初期, Stage VI : エナメル質 基質形成期, Stage VII : エナメル質基質形成末 期

態も順次ととのってくる。また，それにともなっ て細胞間隙，とくに $3 \sim 4$ 個の細胞が接する偶角 部などでは順次その間隙の開大が みられるように 
なり，しかもそれらの領域には microvilli が観察 されるようになる。また，それらの microvilli は 横断面が円形で，直径はほぼ同一である。さら に, 細胞質における rER や mitochondria の数も 初期状態に比してわずかに増加する。また Golgi area も未発達で規模が 小さく，その存在位置は 核の所在が細胞によって多少異なることにも関連 し，必ずしも一定していない。

またこの時期の 細胞では lysosome などの顆粒 状構造物が，初期状態の細胞にくらべ多少みとめ られるようになる。しかしそれらの数はいまだ一 般に少ない。なお象牙質基質形成前の細胞にお ける 機能端細胞膜面は 比較的平滑で, basement membrane を介して歯乳頭の幼若な象牙芽細胞な どに接している。また機能端細胞膜や隣接面細胞 膜などでは， coated vesicle による pinocytosis がみとめられる。しかし象牙質形成前の内エナメ ル上皮には terminal bar は観察されない。

\section{2. 象牙質基質形成初期の内エナメル上皮}

図 5 は象牙質基質形成が 開始されはじめた時期 の内エナメル上皮細胞を示したものである（略図 1 の Stage II, 略図 2)。

（1）細胞の形態について

象牙質基質形成初期の 内エナメル上皮細胞は, 象牙質基質形成前の細胞に比してわずかに伸長す るが，この時期の細胞では, 未だ背丈の低い円柱 形である。しかし象牙質基質形成がはじまるにつ れて，細胞形態はさらにととのってくる。それと ともに，核は楕円形ないし卵円形をなすものが多 くなる。象牙質基質形成初期のものでは核が細胞 質に比して大きく，核の存在位置も細胞のほぼ中 央ないしは中央からやや基底側に位置するように なる。

(2) 隣接面構造について

象牙質基質形成期に入ると, 内エナメル上皮細 胞相互の間隙， とくに $3 \sim 4$ 個の細胞が接する細 胞偶角部などの間隙では，前段階に比してわずか に増大するとともにそれらの領域における microvilli の数もやや増加を示す。しかし microvilli の長さは多少不揃のものも多く，それらの突出方 向もさまざまである。しかし 2 個の細胞が接する 領域では，隣接のものと非常に近接し，とくに核

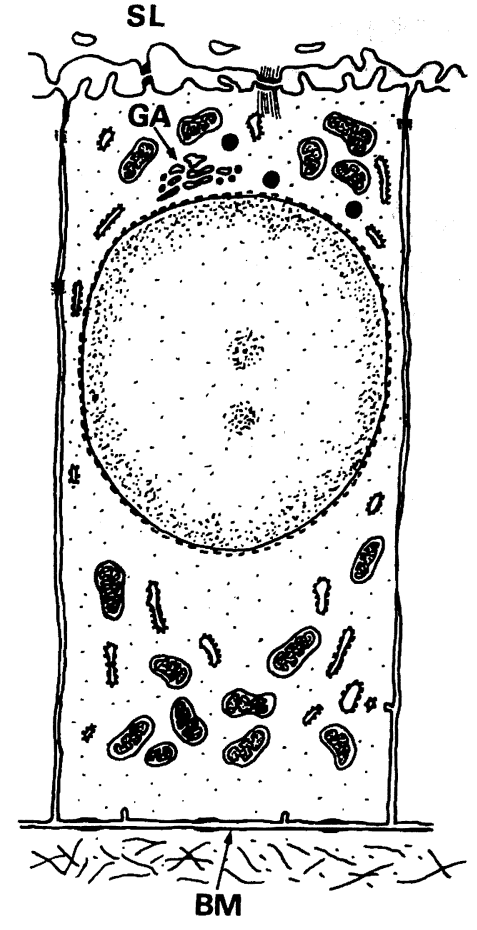

略図 2 象牙質基質形成初期の内エナメル上皮

領域の隣接面細胞膜は比較的平滑な場合が多い。 また隣接面細胞膜には前段階に比してdesmosome や tight junction が多少増加を示している。し かしこの時期における desmosome や tight junction はいまだ数が一般に少なく, 基底側細胞膜 をのぞきそれらの形態も比較的小型で，これに付 随する tonofilament も発達が悪い(図 5 )。

細胞の基底部すなわち エナメル髄の細胞に面し た領域の細胞膜は，一般に不規則な凹凸を示し， エナメル髄の細胞との間には細胞間隙が多く, そ れらの間隙に面する細胞膜には, microvilli が多 く観察される。また内エナメル上皮基底端細胞膜 はエナメル髄の細胞における細胞体の一部, ある いはそれらの細胞突起の一部と接している。しか し，いずれにしても内エナメル上皮の基底端細胞 膜とエナメル髄の細胞と接する領域では, 比較的 大型の典型的な desmosome が観察される場合が 多い。またそれに付随する tonofilament も比較 的長く，発達している場合が多い。

さらに象牙質の基質を構成する collagen 線維 が多数出現しはじめる時期になると, 細胞機能側 
に先がけて，基底側領域に terminal bar が形成 されはじめる。

（3）細胞質の構造について

A) rER と mitochondria

この時期の細胞における rER や mitochondria

は，前段階よりわずかに増加を示す程度である。

また rER は扁平襄状をなすが，それらの長さも 比較的短かく，配列も不規則で，少数の $\mathrm{rER}$ が 細胞質に広く散在しているに過ぎない。 mitochondria は棈円形ないし彎曲した短杆状のものが多 く, cristae mitochondriales は板状であるが，一 般にその数は少ない。 mitochondriaの matrix は 比較的 density が高く, mitochondria granules なども観察される。さらにこの時期の細胞では核 が大きく，その上，核が細胞のほぼ中央に位置し ているために， mitochondria が核より基底側細 胞質と機能側細胞質に分離して存在している。し かし基底端細胞膜ならびに 機能端細胞膜に近接し た領域にはほとんど mitochondria が観察されな いのが普通である(図 5 )。

B) Golgi area

この時期の Golgi area は一般に核より基底側 細胞質で核に近接した領域に存在するが，中には 核の側面に位置しているものもみとめられる。 Golgi complex は象牙質基質形成前の細胞に比し てやや発達を示している。しかし Golgi area は 規模も小さく，小範囲にとどまっている。Golgi lamelle も比較的短かく, Golgi vacuole も少な い。しか Golgi vesicle や coated vesicleなど は Golgi complex の規模が小さい割には多く観 察される。またそのほか Golgi area に sER も 観察されるが，規模も小さくまだ発達も悪い。

C）顆粒状構造物およびその他

細胞によっては Golgi area に lysosome など の顆粒状構造物や multivesicular body なども観 察されるがその数は少ない。

顆粒状構造物は 円形のものや棈円形ないしやや 不規則なものもみとめられ，それらの形態には多 少差がみられる。しかしそれほど大型のものはみ られない。またこれらの顆粒状構造物はすべて限 界膜を有し，その内部はいずれも微細な粒子状構 造物によってみたされている。しかしこれらの顆
粒状構造物には内部をみたす微細な粒子状構造物 がやや少なく，全体として density が比較的低い ものもあれば，粒子状構造物が密で， density が 比較的高いものもみとめられる。またそれら粒子 状構造物が比較的均質な状態を示しているものも あれば，やや不均質な状態を示しているものもみ とめられる。いずれにしても基質形成の初期では, 顆粒状構造物 は一般に少なく，細胞によっては Golgi area にわずかに観察されるものがある程度 で，Golgi area 以外の細胞質には非常に少ない。 さらにこの時期の細胞には rER のほか free の ribosome が細胞質全域にわたって広く散在して いるが，とくに細胞質の機能端細胞膜にごく近接 した領域には free の ribosome があまり観察さ れないのが普通である。そのほか細胞質には 1 2 個の centriole がしばしば観察される。centriole は一般に核より基底側の 細胞質における Golgi area，あるいは基底端細胞膜に近い領域などに観 察される。またこの時期の細胞においても基底端， 隣接面, さらに機能端の細胞膜面では pinocytosis がおこなわれていることから，それらの細胞膜に 近接した領域では，とくに pinocytosisによる coated vesicle が観察される。

（4）硬組織形成と 機能端細胞質の形態と構造 について

象牙質の 基質を 構成する collagen 線維の形成 がはじまると， basement membrane は象牙質基 質の表面に位置する状態になる。

象牙質基質の形成がはじまるまでは，basement membrane といまだ末分化の odontoblast との 間に，比較的細い線維がまばらに，しかも不規則 に配列している。しかし象牙質基質形成がはじま ると, odontoblast の発育後退にともなって collagen 線維が順次増加する。そのさい，最初は odontoblast $の$ lateral process に近接した領域に, これらの線維が比較的密に集積し, しかも basement membrane に平行方向に配列する。さらに それらの線維が odontoblast の後退によって順次 厚さをまし，象牙質基質形成が進行していく。

一方, basement membrane に近い領域では, 象牙質基質の形成がはじまると，かなり細い線維 が basement membrane に対して直角方向に, 
比較的疎な状態で配列するようになり，しかもそ れらの線維は basement membrane に近づくに つれて線維の太さが減少し, basememt membrane の直下では filament 状になって 終っている。ま たこれらの象牙質基質表層の部分は，象牙質基質 の形成が進行しても，その層の幅にはほとんど変 化はみられない。

象牙質基質形成の初期では内エナメル上皮機能 端細胞膜は比較的平滑で，それらは象牙質基質の 表面に位置する basement membrane を介して, 象牙質基質を構成する collagen 線維に接してい る。しかし象牙質基質の形成が進むにつれて，機 能端細胞膜はやや凹凸を示すようになる。さらに 機能端細胞膜には half desmosome が観察され る。

象牙質基質の collagen 線維が 出現しはじめた 時期では， 細胞の基底側に terminal bar が形成 されはじめているが, 細胞の機能端には terminal bar はまだ観察されない。しかし象牙質基質を構 成する collagen 線維の形成が進むにつれて，ま ず細胞の機能端からわずかにはなれた位置に desmosome あるいは tight junction が出現しはじ める。それらは最初不明瞭な形態をなしている が，時期が進むにつれて順次明確となる。

\section{3. 象牙質基質形成後期の内エナメル上皮}

図 6〜8 は象牙質基質の形成が進み，まもなく 象牙質の石灰化が 始まる時期の内エナメル上皮を 示したものである(略図 1 の Stage III, 略図 3 )。

（1）細胞の形態および隣接面構造について

象牙質の基質形成が進むにつれて，内エナメル 上皮の細胞はわずかながら伸長する。それにとも なって，核は細胞体の基底側に位置するようにな る。象牙質基質形成が進むにしたがって細胞の偶 角部からさらに 2 個の細胞が 接する領域に向って 順次細胞間隙が拡大され，それらの離開部はやが て細胞のほぼ全周近くにまで抎大されてくる（図 6 )。しかし， 細胞の核領域隣接面は前段階と同 様，互いに近接している場合が多い。また細胞間 隙が拡大されるにともなって，それらの領域にお ける細胞膜は，彎曲や蛇行などによってやや凹凸 を示すようになるとともに，細胞間隙に打ける microvilli の数もやや増加する。しかし細胞間隙

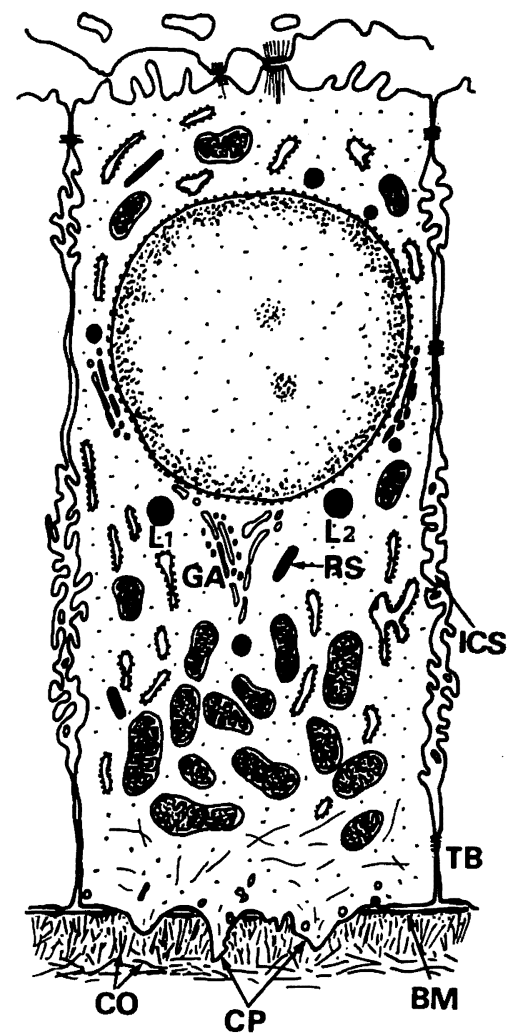

略図 3 象牙質基質形成後期の内エナメル上皮

はすべて一様な状態で離開しているのではなく， 隣接面細胞膜がかなり凹凸を示しているために， 細胞間隙が狭い部位もあれば，やや幅広く離開し ている部位もあり，また隣接細胞相互が比較的平 滑な状態で非常に近接している領域もみとめられ る。しかし細胞膜が非常に近接する領域は比較的 小範囲にとどまることが多く，そのような領域に は desmosome や tight junction が観察される 場合が多い。またこの時期の細胞では desmosome や tight junction が前段階に比してやや発達し, 数もわずかに増加を示してくる。とくに核領域の 隣接面，さらには機能端にやや近い領域などでは 比較的発達した tight junction が観察される場合 が多い。また細胞基底側の terminal bar は前段 階に比してさらに発達を示してくる。

（2） 細胞質の構造について

A） rER および mitochondria

この時期の細胞における mitochondria は, 前 段階と同様な構造を示しており, mitochondria の 
形態も円形のものや楕円形のもののほか，杆状の ものが多く観察される。しかし杆状のものはやや

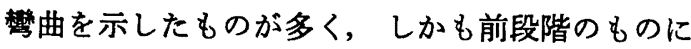
比してやや長いものが多く観察されるようにな る。

さらにこの時期における細胞の mitochondriaの 分布状態は，核が細胞の基底側に位直しているこ ともあって，基底側細胞質には， mitochondria が 比較的少ない。一方核より機能側細胞質において は，核の移動ならびに Golgi area の発達移動に ともなって, mitochondria が核より機能側細胞質 の中央約 $1 / 3 \sim 2 / 4$ 領域に密集している状態で観察 され, mitochondria がそれらの領域で局在性を示 しはじめている(図 6 )。

一方この時期の細胞における rER は前段階に 比してやや数が増し，わずかに発達を示してい る。しかも rER の形態は扁平䨢状であるが, 分 枝した状態が観察されるものも多く，中には複雑 な状態で分枝しているものなどもみられ，それら が非常に不規則に配列している。さらに核より 機能側細胞質における機能端 $1 / 4 \sim 1 / 3$ の領域では mitochondria と rER がほとんど観察されない (図 6 )。

\section{B) Golgi area}

前段階までは Golgi area が主として核より基 底側に位置しているのに反し，この時期における 細胞の Golgi area はその大部分が核より機能側 細胞質に位置するようになる。しかし, Golgi area の一部が核より基底側の 細胞質ないしは核の両側 などにも観察されるものもあり，さらに核の周囲 をとりまくように位置しているものも観察される (図 7)。しかしいずれにしても Golgi area は核 に近接した領域に位置している。またこの時期に おける細胞の Golgi complex はやや発達を示し, とくに核より機能側に位置する Golgi area は, その領域で占める範囲が多少増大している。また この時期の Golgi area では Golgi lamelle など 前段階に比して全般的に長さをまし，総体的に発 達を示すとともに，各種 vesicle や顆粒状構造物 がかなり多量に出現している。また，この時期 の Golgi area には, 前段階に比して, sER が徐 々に発達を示しているのが観察される。
C）顆粒状構造物およびその他

この時期にいたると，とくに Golgi area もし くはその近傍に大小さまざまな lysosome 様顆粒 状構造物，あるいは multivesicular body などが 多く出現し，それらの数が前段階に比して増加し ている。

これらの顆粒状構造物は 球形のものが多いが, なかには不正形のものも観察される。しかしいず れにしてもそれらの顆粒状構造物は明膫な限界膜 を有している。

この時期に出現する 顆粒状構造物を大別すると おおよそ二種に分類される。その 1 つは限界膜に 囲をれた内容物が比較的微細な粒子状構造によっ て密にみたされているもの（説明の便宜上以下 $\mathrm{L}_{1}$ 顆粒とよぶ）で，他の 1 つは限界膜に囲まれ た内容の粒子が前者の顆粒のそれに比してやや大 きく，それらの粒子の構成がわずかに疎になって いる(以下 $\mathrm{L}_{2}$ 顆粒とよぶ)。両者の 顆粒はとも に大きさがまちまちで, しかも中には小さな vesicle がいくつか観察されるものもみとめられる。 しかし, 量的には $\mathrm{L}_{1}$ 顆粒が $\mathrm{L}_{2}$ 顆粒に比しては るかに多い。

またこの時期にいたると前記の二種の顆粒のほ かに，断面がほぽ円形をなし全体として杆状の構 造物が 出現してくる（これらの構造物を以後杆状 体と呼ぶ)。これらの杆状体は限界膜を有し，そ の内部は一般に density が高いものが多い。しか し一個の杆状体においても内容構造が均一な density を示すものもあれば，限界膜に接するごくわ ずかの部分では density が低く，さらにその内層 では最も density が高く，中央部はやや density が低くなっているものも多い。

いずれにしても，以上三種の顆粒状構造物は主 として Golgi area に多く観察され，この時期に おいては Golgi area 以外の細胞質にはまだそれ ほど観察されない。

（3）硬組織形成と機能端細胞質の形態と構造 について

basement membrane は後述のごとくいずれ消 失するが，それまではつねに形成途上の象牙質基 質の表面に位置している。しかし basement membrane に近い基質表層では，かなり細いcol- 
lagen 線維が比較的疎な状態で basement membrane に直角方向に配列している。それらの層は 象牙質基質形成期を通じてほぼ同じ幅を示してい る。しかしそれらの層の深層では比較的太い collagen 線維が非常に密に配列しており，これらの 太い線維は象牙質基質形成がす寸むにつれて順次 増大していく。象牙質基質形成の後期で象牙質の 石灰化期に近づくにつれて, 細胞の機能端に terminal bar が徐々に出現しはじめる。

しかし細胞の機能端に terminal bar が出現し はじめた時期では，一般に terminal bar の発育 が悪く， 細胞の機能端領域に必ずしもその存在が 確認されるとは限らず，細胞によってはまだ観察 されないものもあり，また単に小型の desmosome のみが観察されるものもある。さらにそれらの領 域に desmosome が数個連続しているものもあり， またやや不明瞭ながら, intermidate junction や tight junction などが観察されるものもあって, この時期における terminal bar の構成はかなり 変化にとんでいる。しかしいずれにしてもこれら の時期における terminal bar には, terminal web がまだ観察されない(図 6，8)。

一方，象牙質基質形成が進み，それらに石灰化 がはじまる時期が近づくと，内エナメル上皮の機 能端細胞膜は，それまで比較的平滑であったもの が部分的に凹凸を示し，象牙質基質に向って細胞 小突起が突出しはじめ, さらにそれらの突起が象 牙質基質の表面に位置する basement membrane を貫いて象牙質基質内にわずかに侵入するように なる。したがって細胞小突起が象牙質基質に突出 すると，その部分では basement membrane が 消失する結果となる。しかし, 細胞小突起間など, 小乫起がみられない部分には, basement membrane が観察され，さらにこれらの領域では象牙 質基質表層にみられる細い collagen 線維も，残 存する basement membrane にほぼ直角方向に 配列している状態が観察される(図 8)。以上のよ うに細胞小突起が存在しない部分では, basement membrane は小突起が出現していない時期のもの に比べて，やや不明瞭となるが，それらの領域に は徐々に half demosome が増してくる。なお， これらの細胞小突起は時期が進むにつれて順次数
を増す。

小突起が突出しはじめると, 前述のごとく核か ら機能側細胞質の機能端約 $1 / 3 \sim 1 / 4$ にかけては, mitochondria や rER が減少しほとんど観察さ れなくなる。しかしそれらの領域には, free の ribosome が個々に，あるいは polysome を形成し て観察されるほか，非常に微細な線維状構造物が 多く観察されるようになる。また以上のほかに, それらの領域には微細な tube 状の構造が出現し はじめる。さらに機能端に出現する細胞小突起に は非常に微細な線維状構造物のほか 何ら構造物は 観察されない。

\section{4. 象牙質石灰化期の内エナメル上皮}

象牙質の基質形成がある程度進行すると, やが て象牙質基質に象牙質の結晶の 沈着がはじまる。 象牙質の石灰化は, 形成された象牙質基質の表層 側約 $1 / 6 \sim 1 / 8$ 領域からはじまる。その領域からさ らに象牙質基質の新生追加にともなって，結晶の 沈着が歯乳頭側に向って順次拡大されていくとと もに，一方では象牙質基質表層へ向っても結晶の 沈着が広がっていく。このようにして,ついには 象牙質基質の石灰化が，それらの表面にまで順次 達していく。

図 9 12 1象牙質の石灰化が 象牙質基質の表層 にまで近づいた時期の標本を示したものである (略図 1 の Stage IV, 略図 4)。

（1）細胞の形態および隣接面構造について

象牙質基質の石灰化が それらの表層近くにまで 達する時期では，前段階の細胞に比して細胞の背 丈がわずかに伸長する。それにともなって核はほ とんど細胞の基底端領域に位置するようになる。 この時期になると細胞の隣接面細胞膜は前段階と 同様かなり彎曲や蛇行を示すが，細胞間隙は減少 してくる。しかし隣接面細胞膜には前段階と同様 microvilli が多数観察され，細胞間隙の幅が減少 してくるため, 隣接面に存在する microvilli は複 雑に屈曲や彎曲を示しつつ隣接細胞のものと互い に接し，あるいはわずかの細胞間隙で細胞の長軸 方向に伸長している状態なども観察される場合が 多い。さらに細胞間隙が消失し，隣接細胞間に interdigitationが観察される部位も順次多くなる。 細胞基底端において，エナメル髄の細胞と接す 


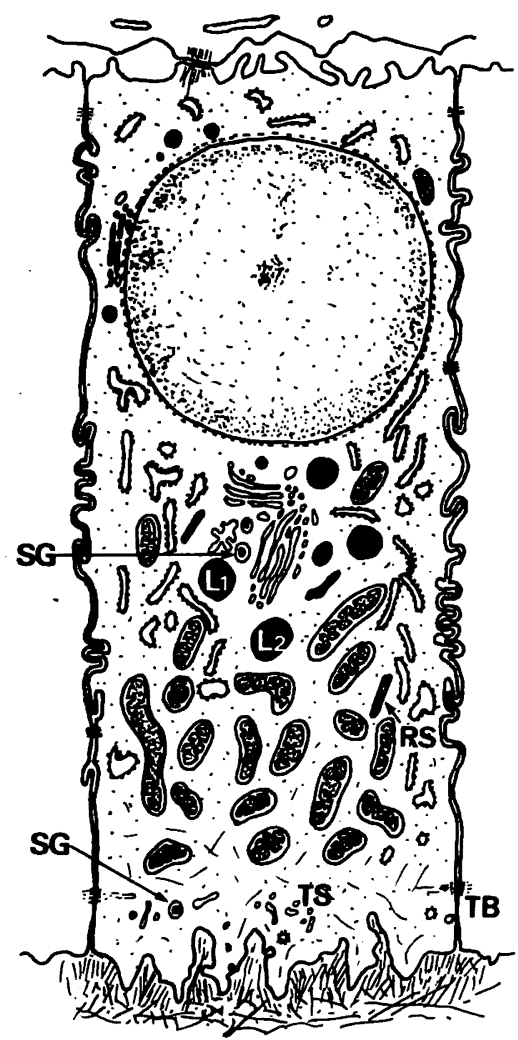

略図 4 象牙質石灰化期の内エナメル上皮

る状態に関しては前段階とほとんど差はみとめら れず，また隣接面細胞膜における desmosome や tight junction などに関しても前段階とほぼ同様 な状態を示している。

また，このような時期においても，基底端細胞 膜, 隣接面細胞膜および機能端細胞膜において は, coasted vesicle による pinocytosis が盛んに おこなわれている。

（2）細胞質の構造について

A） rER および mitochondria

この時期における細胞の rER はわずかに数を まし，その長さむ一般にやや増してくるとともに， 複雑に分枝をなすものが多くなる。しかしこの時 期の rER は彎曲や屈曲あるいは蛇行なども多く みられ，配列の方向もいまだ不規則である。また 細胞の伸長や，機能端における terminal bar の 発育にともない, 細胞機能端で rER などが存在 しない領域が前段階に比してやや増してくる。し かしその他の領域における rER の分布状態に関
しては，前段階の状態とあまり差はみられない (図 9 )。

また mitochondria に関しては，前段階のそれ に比してやや数を増し，とくに長いものが増加を 示す。さらに mitochondria の分布状態に関して は前段階のそれと基本的には 差がみられない（図 9 )。

B) Golgi area

この時期の細胞では Golgi area が核の機能側 に位置するようになる。この時期の Golgi area は前段階のそれに比して，範囲が拡大されるとと もに, Golgi complex も発達し, Golgi lamelle も比較的長く観察されるものが多くなる（図 9, 10)。また Golgi area には sER が増加を示し, $\mathrm{sER} と$ Golgi lamelle ならびに $\mathrm{rER}$ との移行 も観察される。この時期の Golgi area には, Golgi vesicle や coated vesicle あるいは多数の 顆粒状構造物や杆状体が観察されるほか, この時 期になってはじめて分泌顆粒が出現しはじめる。

C） 顆粒状構造物およびその他

この時期における細胞の Golgi area には前段 階の細胞ですでに記載した杆状体および他の二種 の顆粒状構造物 $\mathrm{L}_{1}, \mathrm{~L}_{2}$ 顆粒がほぼ同様な状態で 引き続き観察される。しかしこの時期の細胞では， それらの顆粒状構造物が Golgi area ならびにそ の近傍のみならず，機能側細胞質にも比較的広範 囲に観察されるようになる(図 9，10)。またこの 時期にいたると分泌顆粒は Golg area のみなら ず機能端細胞質にまで 観察されるようになる（図 $11,12)$ 。

（3）硬組織形成と機能端細胞質の形態と 構造 について

象牙質基質の石灰化期になると，機能端細胞膜 には細胞小突起が増加するとともに，それらの小 突起間には, 細胞膜愁入が観察されるようになる。 そのため機能端細胞膜は全体としてかなり不規則 な凹凹を示すようになる(図 $9 ， 11 ， 12$ )。

また， 小突起の増加と細胞膜彎入の出現によっ て機能端細胞膜に比較的平滑な面が消失すると, basement membrane はもはや観察されなくなる (図 9，11，12）。細胞膜彎入の形成と basement membrane の消失にともなって，象牙質基質表層 
の collagen 線維は 細胞膜彎入部に 侵入するよう な結果となる。それにともなって象牙質基質の表 面は，それに接する内エナメル上皮の機能端にお ける小突起や細胞膜彎入の 外形に対応してかなり 凹凸を示してくる。また細胞膜彎入部においては， 象牙質基質表層の微細な collagen 線維が 内エナ メル上皮の長軸とほぼ一致した方向に配列し，そ れらは細胞膜彎入部の深部に向かうにしたがって 太さと数が順次減少し, 消失している。

さらに象牙質の石灰化が 基質表層に接近するよ うになるにしたがって，象牙質表層の collagen 線維はその数が減少するとともに配列がややみだ れてくる。

ついで，象牙質の石灰化がさらに進行し，基質 表層の collagen 線維のみが 未石灰化のまま残存 しているような状態となる頃には，それらの表面 に残存した collagen 線維は数が一層減少すると ともに, 配列が非常に不規則になる。また，これ らの未石灰化の collagen 線維の 数が 減少するの にともない，いまだこれらの線維がわずかに残存 している間に，すでに機能端細胞膜と石灰化した 象牙質表面との間に, amorphous material が出 現しはじめる(図11)。

また機能端領域における terminal bar は, 総 体的に前段階に比してやや発育し, terminal bar として確認されるものがはるかに増加し，それに 付随する terminal web もいまだ不完全ではある が出現しはじめている。また，なかには，機能端 から基底側に向かって徐々に移動を開始するもの もまれには観察される。

細胞の機能端で, terminal bar が位置する部分 より機能側細胞質には，rER や mitochondria がごくまれにみられる程度である(図 9，11，12）。 しかし，それらの機能端領域の細胞質には，free の ribosome がわずかに散在するほか，前段階の 細胞と同様, 微細な tube 状構造物が不規則に配 列している。しかしこれらの tube 状構造物の数 は前段階に比して増加を示している。またそれら のほか機能端細胞質にも分泌顆粒が 出現している (図11, 12)。

なお機能端細胞膜彎入部においても coated vesicleによる pinocytosis が盛んなため, 機能端

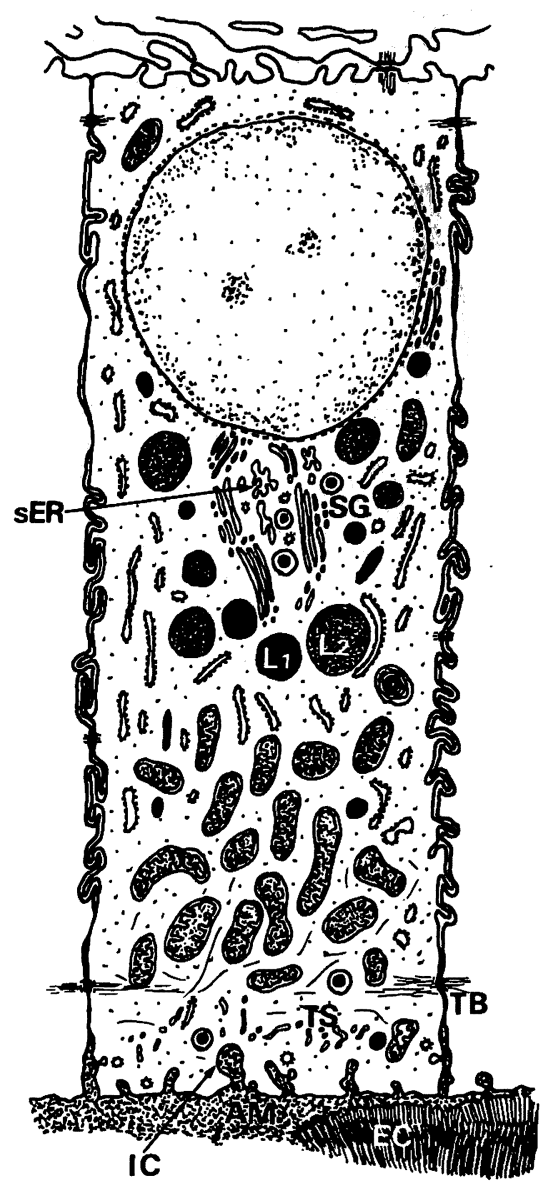

略図 5 エナメル質基質形成初期のエナメル芽 細胞

細胞質には pinocytosisによる coated vesicle が 比較的多く観察される。

5. エナメル質基質形成初期のエナメル芽細胞 前項で述べたごとく石灰化した象牙質の表層 に，象牙質基質表層の collagen 線維がわずかに 残存している時期に,すでに amorphous material が出現しはじめ，象牙質基質の石灰化が，その最 表層にまで達するのとほぼ時を同じくして，それ らの amorphous material 中で, 象牙質の表層に エナメル質の結晶が沈着しはじめる。

沈着直後のエナメル質結晶は 非常にうすいリボ ン状の結晶で, 内エナメル上皮の長軸に一致する 方向で配列する。図13 20はエナメル質基質形成 初期の標本を示したものである（略図 I の Stage $\mathrm{V}$, 略図 5 )。 
（1）細胞の形態と隣接面構造について

エナメル質基質形成が はじまる時期の内エナメ ル上皮は前段階に比してわずかに背丈が伸長し, 核は細胞の基底端に位置している(図13)。しかし エナメル質の形成がさらに進むにつれて，細胞長 がわずかながら伸長していく(図17)。

エナメル質形成初期の細胞では 細胞間隙がほと んどみとめられず，細胞隣接面においては，エナ メル質基質形成が進むにつれて隣接のものと interdigitation をなす領域がさらに増加してくる。

また機能側の terminal bar は，それに付随す る terminal web とともにさらに発達し明瞭とな る。また terminal bar は, はじめ機能端に位置 しているが， 細胞小突起や細胞膜彎入が多数出現 し, さらにエナメル質の結晶が沈着し始める頃に なると, 機能端からわずかながら徐々に基底側方 向に向って後退しはじめる（図13，16，17，20）。

一方基底端領域においては, 前段階とほとんど 変化がみられない。

（2）細胞質の構造について

A） rER および mitochondria

この時期における細胞の rER は総体的にやや 発達し，数もわずかながら増加する。しかし rER の形態や分布状態その他は前段階とほぼ同様であ る。mitochondria においてもほぼ同様で, 長楕 円形もしくは杆状のものが多く，比較的長いもの がわずかながら増加している。また mitochondria は前段階と同様, 細胞の機能側で terminal web の基底側近傍に局在している（図13，16，17）。し かし中には terminal web を越えて機能端細胞質 内に侵入しているものもわずかに観察される（図 17)。

\section{B) Golgi area}

この時期における Golgi area はさらに発達を 示し，とくに核より機能側では Golgi area の範 囲が順次拡大される。それにともなって，Golgi lamelle は長さを増し, その両端や周辺に Golgi vesicle あるいは coated vesicle が増加してくる。 また Golgi area では sER がさらに発達し，

Golgi lamelle や rER と連絡している部位も多 くみられる(図18，19)。Golgi area あるいはその 近傍に分泌顆粒をはじめ, 後述する大小様々の lysosome その他の顆粒状構造物や，杆状体など が順次増加を示す(図14，18，19）。

C） 顆粒状構造物およびその他

この時期では大小さまざまの 顆粒状構造物がさ らに増加を示し，それらは主として Golgi area もしくはその近傍に観察されるほか，一部は機能 側細胞質にもみとめられる。この時期の Golgi area には前段階においても記載した $\mathrm{L}_{1}$ 顆粒お よび $\mathrm{L}_{2}$ 顆粒のほか，それらの中間型のものや， 分泌顆粒，あるいは multivesicular body さらに lamellar body などが観察される。しかし前段階 までは $\mathrm{L}_{1}$ 顆粒が $\mathrm{L}_{2}$ 顆粒に比して多いのに反し， この時期ではその内容物の density に多少の差は 認められるものもあるが，総体的に $\mathrm{L}_{2}$ 顆粒の方 が多くみとめられるようになり，しかも $\mathrm{L}_{2}$ 顆粒 の方が一般に大型のものが多いように思われる (図13，14，18，19)。

これらの顆粒状構造物は一般に Golgi area な らびにその近傍に多く出現しているが， Galgi area 以外の細胞質，とくに機能端などにも観察さ れるようになる。これらの顆粒状構造物のほか, 杆状体は主として Golgi area に多く見られるが， その他の細胞質にも広く出現し，全体としてその 数が増加してくる。また分泌顆粒も総体的に数が 増加してくる(図16，18，19，20)。そのほか細胞 の機能側領域で， mitochondria が密に集積する 領域では, mitochondria の間隙に非常に微細な 線維状構造物が密に出現している。なお free の ribosome の分布状態に関しては前段階と同様で ある。その他核の近傍や Golgi area には centriole が観察される場合もみとめられる。

さらにこの時期においても基底端細胞膜や隣接 面細胞膜,さらには機能端細胞膜に coated vesicle による pinocytosis が盛んである(図16，20)。

（3）硬組織形成と 機能端細胞質の形態と構造 について

象牙質基質の最表層に向かっての石灰化の進行 と，基質最表層に残存する collagen 線維の減少 消失にともなって，機能端細胞膜の小突起ならび に累入の数と規模が減少していく。

したがってエナメル質の結晶が 出現する直前の 時期では，細胞膜の小突起や彎入などの減少にと 
もない，不規則な突出や陥凹により機能端細胞膜 は不規則な凹凸を示す状態となる(図16)。

しかしエナメル質の結晶が 沈着しはじめると， エナメル質の結晶はつねに機能端細胞膜面に近接 した領域に形成され，しかもエナメル質の形成面 が比較的平滑なことにも関連して，機能端細胞膜 面はエナメル質形成面と同様総体的に平滑な面と なる(図13，16，17，20)。

一方エナメル質の結晶沈着がはじまると，機能 端細胞膜には再び細胞膜彎入が出現しはじめる。 これらの細胞膜彎入は，最初平滑な細胞膜面にわ ずかの細胞膜陥凹や彎入として生ずるが, terminal bar の後退にともなって，それらの彎入度が 次第に増すようになる。また細胞膜彎入部は, amorphous material によってみたされている(図 20)。

象牙質の石灰化期に出現する細胞膜彎入は, 細 胞小突起間に出現し, 細胞膜堕入の形態が不規則 であるが，エナメル質基質形成期では機能端細胞 膜が平滑で, 細胞小突起が存在しないことと, 細 胞膜彎入度が， terminal bar の位置が後退するこ とにも関連し，象牙質石灰化期のそれに比して一 般に強く，またその断面が比較的円形に近い管状 のものが多く，さらにそれらが分枝した状態を示 すものも多い(図20)。

また前述のごとく，エナメル質の形成が開始す ると，機能端における terminal bar が徐々に後 退しはじめる。それにともなって terminal bar より機能端隣接面は，順次多少不規則な凹凸を示 すようになり，隣接細胞との間に不規則な間隙が 生じ，その領域にも amorphous material が出現 しはじめる。これらの間隙は細胞偶角部などにと くに多く観察される。

またこれらの細胞間隙の amorphous material は，細胞嶰入部その他の 機能端細胞膜外に出現し ている amorphous material と連絡している（図 $16,17,20)$ 。

また terminal bar の後退と terminal web の 発達にともない機能端領域における微細な tube 状の構造物はさらに增加を示し，それらが複雑に う曲や蛇行しているのがみとめられる。またこれ らは一部 terminal web を越えてさらに細胞質の
内方にまで侵入しているものもみとめられる（図 $15,16,20)$ 。

機能側で rER が消失する部位では, rER の消 失に先だち，それに付随する ribosome のみが消 失しているものが多く観察され，機能端における tube 状構造がこれに連絡している状態も観察さ れる。またこの時期では, 機能端細胞質に出現す る分泌顆粒が一般に増加してくる。杆状体や mitochondria あるいはその他の lysosome 様の顆 粒状構造物も一部 terminal web を越えて機能端 細胞質に観察される場合もある。さらに，この時 期では機能端細胞質に, 非常に微細な線維状構造 物が一般に増加を示す。また terminal bar より機 能端の隣接面ならびに機能端の細胞膜には pinocytosis が盛んなこともあって coated vesicle も かなり多く観察される(図16，20)。

\section{6. エナメル質基質形成期のエナメル芽細胞}

図21 26はエナメル芽細胞が最長となり完全に 分化をおこした時期の標本を示したものである (略図 1 の Stage VI, 略図 6 )。

（1） 細胞の形態と隣接面構造について

エナメル質基質形成がやや進むにつれて，内エ ナメル上皮はさらに背丈を伸長し，やがて細胞長 が最大となる。核は細胞の基底側に位置し, Golgi area および rER の発達をともなって，内エナメ ル上皮は完全に典型的なエナメル芽細胞に分化す る。

この時期のエナメル芽細胞は 隣接の細胞と互い に偶角部においても非常に近接しており，細胞間 陌はほとんどみとめられない。それにともない隣 接面細胞膜が interdigitation をなす領域も増大 する。また細胞の伸長にともない desmosome や tight junction がさらに発達を示すようになる。

また機能端領域の terminal bar は一層発達し, それらが機能端からわずかにはなれた位置に固定 されるよらになり， terminal web も発達を示す ようになる(図21，22)。

しかしェナメル質形成期においても，ワニのエ ナメル芽細胞では，芽細胞の機能端に哺乳類のエ ナメル質形成期にみられるようないわゆるトーム スの突起は形成されない。

（2）細胞質の構造について 


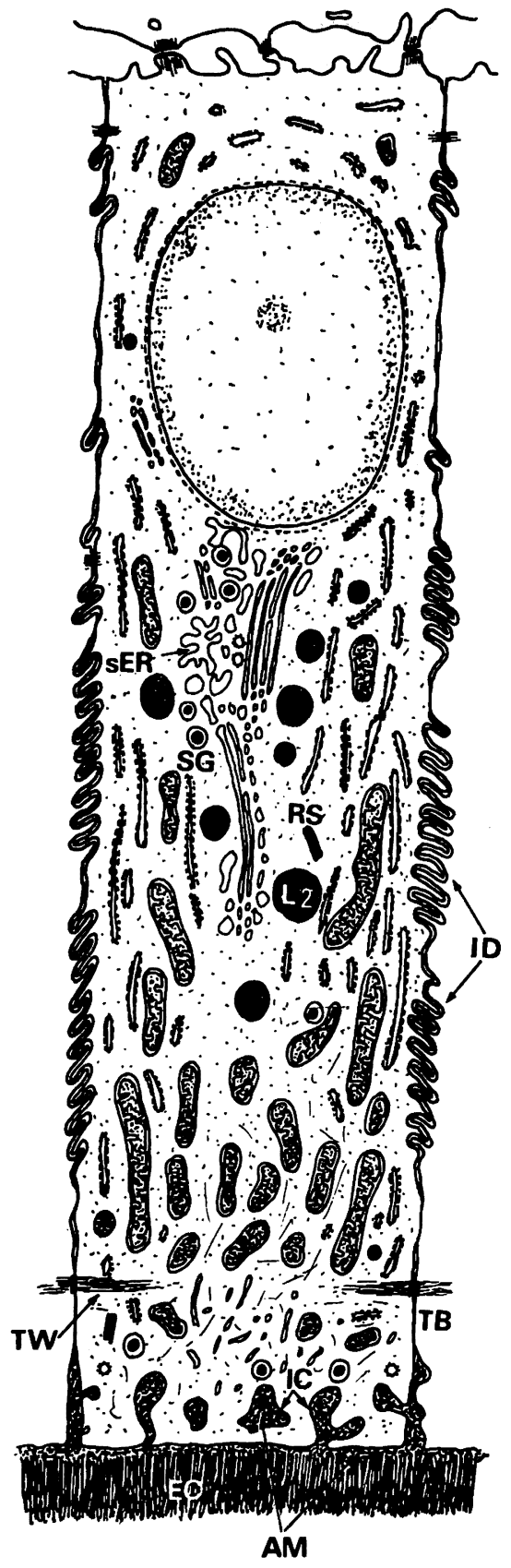

略図 6 エナメル質基質形成期のエナメル芽細胞

\section{A） rER ならびに mitochondria}

mitochondria は 芽細胞の 伸長その他発育にと もなって, 円形や棈円形のもののほか，順次長杆 状のものが増加し，それらは蛇行や彎曲などを示 すものが多く，ほぼ細胞の長軸方向に配列するよ うになる。 しかし，mitochondriaの構造に関しては前段階 のものと差はみとめられない。また mitochondria は，細胞の伸長にともなってわずかに数をまし， terminal web の基底側領域に密に集積し，前段 階と同様局在性を示している(図22)。

これらの mitochondria は密に集積した部位以 外の細胞質にも，ごくわずかながら散在している がその数は少ない。また terminal webをこえた 機能端細胞質にも mitochondria が侵入している 状態もわずかながら観察される。

一方 rER は芽細胞の伸長と, 機能端の terminal bar の移動にともない順次発達し, 数の増 加とともに扁平襄状の rER が芽細胞の 長軸方向 に比較的密に配列するようになる(図22)。しかし Golgi area ならびに mitochondria が密に集積し ている細胞質領域では rER が非常に少ない（図 22)。

B) Golgi area

エナメル質基質形成期における細胞の Golgi area は, 主として核の機能側に位置しているが, 細胞の伸長や rER の発達などにともなって Golgi area はさらに発達し, 核の機能側で核に近接 した領域からさらに機能側に向かって Golgi area の占める範囲が順次拡大され，核より機能側細胞 質のほぼ中央領域にまでおよぶようになる。それ にともなって Golgi lamelle も順次長さを増し, Golgi area における vesicle や coated vesicle も広範囲に出現するようになる。また Golgi area における $\mathrm{sER}$ もさらに発達し，不規則に分枝し， 全体として複雑な網状配列をなしている（図24）。

Golgi area には短い不規則な rER がごく少 量存在するにすぎない。さらに Golgi area では sER の一端が Golgi lamella の一部に連絡する 状態も観察され，また $\mathrm{sER}$ と rER との連絡移 行する状態も多く観察される。

エナメル質基質形成期における Golgi area に は，分泌顆粒が非常に多く，それらの分泌顆粒は Golgi area 全域に出現しているが，概して sER が存在する領域に多くみとめられる(図24)。また Golgi area には分泌顆粒以外に杆状体や $\mathrm{L}_{2}$ 顆粒 その他の lysosome 様の顆粒状構造物，あるいは multivesicular body などが比較的多く観察され 
る。

C） 顆粒状構造物およびその他

この時期のエナメル芽細胞には，Golgi area な らびにその他の細胞質に杆状体が広く分布し，そ れらは基質形成期で 細胞体の伸長にともなって数 が増加している。これらの杆状体は限界膜に接し たごくわずかの幅の領域では density が低いもの もあるが，一般に外層は density が高く，杆状体 の内層は density が低くなっている。しかし杆状 体の内層では杆状体の長軸に 直角方向に横紋構造 がみられるものも観察され，それらの横紋構造は density の高い部分と低い部分とが 交互に配列し 縞構造を呈している。またこの時期における Golgi area ならびにその他の 細胞質には，前述のごと く多数の分泌顆粒が観察されるようになるが， $\mathrm{L}_{1}$ 顆粒は順次減少消失し, やがて $\mathrm{L}_{2}$ 顆粒のみとな る。一方, その他の顆粒状構造物については前段 階の状態と基本的に差はほとんどみられない（図 24)。

またエナメル質基質形成期の細胞質には，図 25，26にみられるような特殊な 顆粒状構造物が観 察される。これらの顆粒状構造物は，やや不明瞭 ながらも限界膜に囲まれ，それらの内部には針状 ないしは非常に薄い板状の 結晶様構造物が比較的 密に観察され，それらがほぼ放射状に配列してい る。これらの特殊な顆粒は，いずれも核より機能 側の細胞質で Golgi area の近傍，あるいはその他 の細胞質に出現するがその数は少ない。

以上のほか Golgi area には centriole が $1 \sim 2$ 個観察される場合もあり，それらの centriole は Golgi area でも核に比較的近い部位に出現する場 合が多い。

（3）硬組織形成と機能端細胞質の形態と構造に つฟT

mitochondria が密に集積している領域では， 前述のごとく rER が少なく，また free の ribosome も比較的少ない。それらの領域における各 々の mitochondria の間隙には非常に微細な線維 状構造物が観察される。さらに terminal webを こえた機能端細胞質には, mitochondria や rER が少ないのが普通であるが，それらの領域には mitochondria と rERがごくわずかに観察される
場合もある。また rER が存在する場合でも，そ の領域に観察される $\mathrm{rER}$ は形態も小さく, 配列 も不規則で，わずかに個々散在している程度に過 ぎない。

そのような機能端細胞質には free の ribosome も少なく， 細胞質の基質には非常に微細な線維状 構造物のほか微細な tube 状構造物が かなり多数 観察される。それらの tube 状構造物は複雑にう 曲や蛇行あるいは分枝し，一部は機能端細胞質か ら terminal web をこえた領域にまで分布してい る状態もみとめられる。このような機能端細胞質 には分泌顆粒が比較的多く観察され，その他杆状 体や lysosome 様の顆粒状 構造物も観察される (図21)。

また terminal barより機能端の隣接面には前 段階と同様細胞間隙が観察され，amorphous material が密に集積するようになる(図21)。

一方, 機能端の細胞膜は比較的平滑で, エナメ ル質の幼若な crystal が機能端細胞膜に近接した 領域に沈着している。なおエナメル質の結晶はす べて芽細胞の長軸に一致した方向に 配列している （図21，22）。また機能端の 細胞膜外には amorphous material が密に集積している。また機能端 細胞膜には細胞膜彎入部がみられ，それらの細胞 膜彎入は管状をなし, 細胞の伸長と terminal bar の移動にともなって細胞質深部に 向かって彎入度 が増していく。またこれらの細胞膜彎入部にも amorphous material がみたされている(図21)。 しかし，エナメル質基質形成期においては，これ らの細胞膜彎入が terminal bar をこえた深部に 達することはない。

さらに terminal bar より機能端領域の隣接面 ならびに機能端細胞膜には coated vesicle による pinocytosis が盛んで, これらの pinocytosis は比 較的平滑な部位のみならず, amorphous material が密に集積した機能端隣接面ならびに 細胞膜彎入 部の細胞膜にも観察される。したがって機能端の 細胞質に pinocytosis に起因する coated vesicle もかなり多く観察される(図21)。なお，前述した ごとく，ワニでは哺乳類にみられるような，いわ ゆるトームスの突起の形成はみとめられない。 


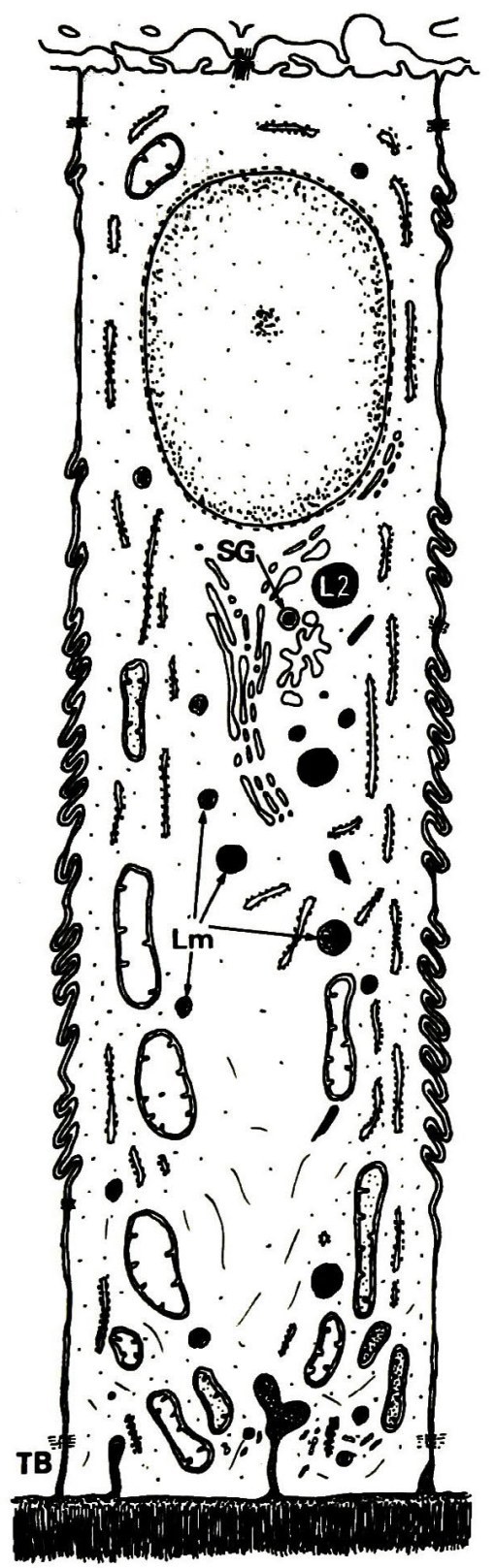

略図 7 エナメル質基質形成末期のエナメル芽 細胞

\section{7. エナメル質基質形成末期の エナメル芽細胞} エナメル質の基質形成がすすみ，将来のエナメ ル質全幅の形成がほぼ終わりに近づき，基質形成 の最終段階になると，エナメル芽細胞は次の maturation stage の準備段階として，基質形成期か ら maturation stage への移行の状態に入る。し
たがってェナメル来細胞の 細胞質の状態も順次変 化を示してくる。図27３1はこの時期の標本を示 したものである(略図 1 の Stage VII, 略図 7)。

（1）細胞形態と隣接面構造について

エナメル質基質形成の末期においても，エナメ ル芽細胞の背丈は 前段階と同様で背丈の高い状態 を保っている。

細胞の隣接面形態においても基本的には前段階 と同様で, 核領域以外の部位では interdigitation をなす領域がかなり多く観察される。

一方機能端における terminal bar は基質形成 、期の末期になると，機能端からややはなれた位置 から順次機能端に向って移動し, terminal bar が 機能端近くに位置するようになると，やがて terminal web の発達も順次低下し, 不明瞭となる (図27, 28, 31)。

（2）細胞質の構造について

\section{A) rER と mitochondria}

terminal bar の機能端への移動などがみられる 基質形成末期で maturation stage への移行期に なると, rERの数が徐々に減少し, それにともな ってそれらの配列も順次不規則となっていく（図 27, 28)。

一方, mitochondria は terminal bar の位置が 機能端からまだはなれていて, terminal web が 明瞭に観察される時期では, mitochondria の形 態や構造ならびに分布状態など 前段階とまったく 同様である。しかし terminal bar の位置が機能 端へ移動するにともなって, mitochondria が密 に集積した部位も細胞の機能端一移動する。さら に細胞によっては, それらの mitochondria の中 で形態はまったく同一であるが, mitochondria の matrix の density が低く, matrix が明調に 観察されるものが出現してくる(図27)。

ついで細胞質全域の mitochondria の matrix はすべて明調なものに変わり, それらの mitochondria の形や cristae の状態にはあまり変化 がみられないが, 前段階の mitochondria に比し て, その径がやや増してくる。また mitochondria の分布状態も変り, 順次局在性は失なわれ, 細胞 質に広く散在するようになる(図27，28)。

B) Golgi area 
エナメル質基質形成末期で, terminal bar の移 動ならびに mitochondria の構造や分布状態に変 化が生ずる時期に近づくにつれて Golgi area に は, 分泌顆粒が存在しているほかに，大小様々な lysosome 様の 顆粒状構造物が順次増加を 示して くる。また, terminal bar の移動, rER の減少 とともに, mitochondria の構造や分布状態に変 化をきたした直後までは，Golgi area の分布状態 や大きさなどにあまり変化はみられず，Golgi complex の状態なども前段階とほぼ同様で, Golgi area には分必顆粒もまだ多く認められる(図29)。

しかし, さらに terminal bar の移動や mitochondria の分布などの変化が一層進むとやがて, Golgi areaには分泌顆粒が消失し, 順次前述の大 小様々な不規則な形態の 顆粒状構造物のみが比較 的多数観察されるようになる(図30)。

また Golgi area に分泌顆粒が 観察されなくな るのにともなって, Golgi area の分布範囲は, エ ナメル質基質形成の最盛期に比してわずかに縮少 する。

C） 顆粒状構造物およびその他

基質形成末期で terminal bar の位置や mitochondria の分布などに変化が生ずる時期が近づ くにつれて，エナメル芽細胞の Golgi area やそ の他の細胞質には大小様々な lysosome 様の顆粒 状構造物が順次増加を示してくる。それらの顆粒 状構造物は，前段階から引き続き観察されている $\mathrm{L}_{2}$ 顆粒と, $\mathrm{L}_{2}$ 顆粒に比してかなり微細な粒子 状構造物を含み，限界膜をもった顆粒状構造物と からなる。さらに後者の顆粒は, 比較的 density の均一な状態の微細粒子が 分布しているものと, これらに density の高い同大の微細な粒子状構造 物が混在しているものとがみられる。その際, density の高い粒子の密度が 比較的疎な状態で分 布しているものもあり，さらに density の高、微 細な粒子が比較的均一な状態で分布しているもの もあれば，部分的に群集しているものも多く，そ れらの顆粒状構造物の内容に関してはかなり変化 に富んでいる。この時期における lysosome 様の 顆粒状構造物のなかで $\mathrm{L}_{2}$ 顆粒を除くこれらの顆 粒状構造物を記載の便宜上, 以下 $\mathrm{Lm}$ 顆粒とよ ぶ。
$\mathrm{Lm}$ 顆粒の形態は円形のもの，棈円形のものの ほか, 非常に不規則な形態のものも多く，それら はかなり変化にとんでいる。また，とくに Lm 顆 粒はエナメル質基質形成の末期に増加をはじめる が, これらの顆粒は最初 Golgi area に多数出現 し, terminal bar の移動, mitochondria の構造 や分布などの変化ならびに 分泌顆粒の消失などに ともなって他の細胞質領域にも順次増加を示すよ うになる（図27，28，29，30，31）。また杆状体は エナメル質基質形成末期においても引き続き観察 される。

mitochondria の局在性が失なわれる時期で, mitochoncria が順次消失していく際, その領 域に mitochondriaに代って, rER や free の ribosome 等は出現することがなく，非常に微細な 線維状構造物のみが観察されるようになる（図27, 28)。

さらに, mitochondria の局在性がまったく消 失し, 比較的 density の低い matrix をもつ mitochondria のみが細胞質に広く散在するようにな ると, 前段階まで mitochondria が密に集積して いた領域においても，他領域の細胞質とまったく 同様な状態となる(図31)。

（4）硬組織形成と 機能端細胞質の形態と構造 について

エナメル質基質形成の末期においても，terminal bar の移動や rER の状態, さらに mitochondria の分布などの変化が生ずるまでは, エナ メル芽細胞の機能端にお污る細胞膜や細胞質の構 造は前段階とまったく変化がみられない。

しかし, 機能端の terminal bar や mitochondria の分布などに変化を生ずるのにともなって，機能 端細胞質ではその形態や 構造に多少変化が生じて くる。すなわち terminal bar が機能端に移動を 完了してもなおしばらくの間，前段階と同様な状 態で機能端細胞膜の彎入がみとめられ，それらの 細胞膜彎入部にはなお amorphous material が密 に集積しているが，やがて機能端における細胞膜 彎入の数は徐々に減少する。しかしその反面深部 に向っての細胞膜の彎入度は強くなり，このよう な状態となっても彎入部や機能端細胞膜外には, 前段階と同様に amorphous material が依然観察 
される。

一方, terminal bar が細胞の機能端へ移動する のにともない，それまで主として terminal web の基底側に接する位置に存在していた mitochondria の集団は, terminal web の移動にしたがい, わずかに数が 減少しつつ細胞の機能端に移動して いく。また, その際 terminal web の発達の低下 にも関連して, terminal web を越えてそれより さらに機能端細胞質に mitochondria や rER の 侵入する状態が多くなる。

また terminal bar が機能端に移動し，それよ り機能端の細胞質が 少なくなるのにともなって, 機能端細胞質における微細な tube 状構造や分泌 顆粒は減少し, terminal bar が機能端に移動を完 了し, さらに terminal web の発達度が低下する にともなって，微細な tube 状構造や分泌顆粒は すべて観察されなくなる。したがってそれ以後の 細胞機能端には, rER や mitochondria ならびに free の ribosome, 前述の $\mathrm{Lm}$ 顆粒のほか, 細胞 膜の pinocytosis によって生じた, coated vesicle などが観察されるのみとなる。

一方, 機能端隣接面細胞間隙に出現していた amorphous material もついには観察されなくな り，エナメル質の基質形成がすべて完了する。

\section{考察}

爬虫類の歯に関する古い時代の観察所見は，主 として各種のへビの毒牙に関する形態とそれらの 組織学的観察がほとんどで, 発生学的観察は少な い。しかも，これらの発生学的観察は, 人ビの毒 牙の形態形成のほか, 主としてそれらの歯胚群や 歯堤に関するごく簡単なものが多い。

しかし近年では，とくにエナメル質に関しては， ワニやトカゲの歯について観察され，しかもそれ らの発生学的観察が主になっている。

一方, 魚類や両生類から爬虫類にいたる各種動 物のエナメル質に関する従来の 発生学的研究 で は，緒言の項でも述べたごとく，エナメル質の発 生由来に関係するものが多い。初期時代から今日 まで, 多数の研究者がそれぞれの動物における エナメル質の発生由来に関する見解が出され，エ ナメル質に関する発生学的研究の焦点となってい
る。

ワニやトカゲなど爬虫類のエナメル質に関する 最近の発生学的観察では，歯の交換様式に関する もののほか，エナメル芽細胞ならびにエナメル質 形成について, 数人の研究者が光学顕微鏡を用い て観察をおこなっている。

従来の研究から， ワニやトカゲなどの歯は,

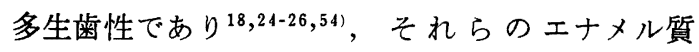
は哺乳類のエナメル質と同様, 外胚葉由来であ るということに関しては今や定説となってい $る^{14,16,17,25,31,32)}$ 。しかし爬虫類のエナメル質に関 する従来の組織学的ならびに発生学的観察は, 、 ずれも断片的で，しかも比較的簡単な観察にとど まっているものがほとんどで，とくにそれらに関 する電子顕微鏡的観察はみられない。

爬虫類の歯, とくにワニの歯は魚類あるいは両 生類の歯から哺乳類の歯への移行として, 比較発 生学的に重要な位置を占めているにもかかわら ず，爬虫類におけるエナメル質に関しては今なお 不明な点が多い現状である。

そこで著者は, 比較発生学的見地から歯の形成 機構を究明する研究の一端として, 爬虫類のワニ を材料に用いた。本研究に先だち，著者はまずワ ニにおける歯胚の 発育状態あるいはエナメル質そ の他の歯を構成する各組織の形成状態や組織学的 構造について, 光学顕微鏡を用いて観察するとと もに，とくにエナメル質の形成や組織構造につい ては走査電子顕微鏡および透過電子顕微鏡を用い てあらかじめ観察を行なった ${ }^{47,49,52,53) 。 ~}$

本研究では, ワニにおけるこれらの所見と, ワ 二以外の歯に関する著者らの従来の所見 $43-46,48,50-$ 51,55-62)をもとに，ワ二の内エナメル上皮の初期状 態から，エナメル質基質形成が完了するまでのエ ナメル質形成にともなうエナメル芽細胞の形態と 微細構造の推移変化について，主として透過電子 顕微鏡を用いて観察をおこない，さらに著者は， これらのワニの観察所見をもとに，エナメル質の 比較発生学的見地から, 爬虫類のみならず，魚類 や両生類からさらに哺乳類にいたるまで籁囲を広 げて比較検討し，考察を行った。

1. 細胞形態の基本的推移変化について 硬組織形成前の内エナメル上皮初期状態に関す 
る電顕的観察で, 魚類に関しては脇田 $(1974)^{35)}$ と 小野 $(1974)^{36)}$ がそれぞれニザダイとイシダイで, Herold $(1974)^{63)}$ が Pike で観察をおこない，さら に両生類では Zakiら (1970) ${ }^{64)}$ が Rana pipiens を用い, Smith ら (1971) ${ }^{65)}$ はイモリで，また哺乳 類では Pannese $(1962)^{66)}$ がネコで, Decker $(1963)^{67)}$ その他 ${ }^{68-72)}$ が ラットの切歯を用いて観察 を行なっている。

それらの所見を総合すると, 内エナメル上皮の 未分化な初期状態では細胞形態の多くは立方 形 ${ }^{64,71)}$ ，短円柱形 $\left.63,66,70,72\right)$ を呈するが，その他不 規則なもの ${ }^{67,68)}$ ないしはクサビ状 ${ }^{65)}$ などの表現が なされているものもある。

しかし爬虫類に関する電顕的所見はいまだみら れないが, $\operatorname{Kvam}(1958 b)^{16)}$ は光顕的観察で, この 時期のワニ (Alligator mississippiensis Daud) の内エナメル上皮は立方形であると述べている。 著者が観察を行なったワニの所見においても，内 エナメル上皮の初期状態では, 魚類や両生類なら びに哺乳類における所見とほぼ同様で, ごく初期 の細胞は不規則な形態の立方形であるが，象牙質 基質形成期に近つくにつれて，順次細胞の背丈が 伸長するのにともなつて, 細胞形態も短円柱形に ととのってくる。

さらに硬組織形成と細胞の伸長ならびに核の移 動などについては, 魚類の歯と両生類から哺乳類 にいたる畨の形成状態によって異なる。魚類のエ ナメル質は象牙質の基質形成に先だち, エナメル 質の基質を構成する collagen 線維の形成に始ま る。さらに将来のエナメル質表層から樑層に向か

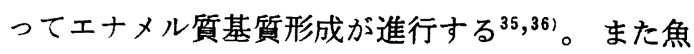
類では内エナメル上皮の細胞が伸長しはじめると まもなく，エナメル質基質を構成する collagen 線維の形成が始まる。collagen 線維の形成期の前 期までは，核は細胞のほぼ中央から基底側に位置 するが，形成期の中期になると，細胞の基底側に 核が移動する。一方，エナメル質基質の collagen 線維の形成時には，エナメル芽細胞が急速に背丈 を伸長し，分化を起こし，基質形成が完了する頃 にはエナメル牙細胞は最長となる。かくしてェナ メル質基質形成が完了すると，基質の深層から表 層に向つて crystal の沈着が開始する ${ }^{35,36) 。 ~}$
両生類では象牙質基質形成期に内エナメル上皮 の伸長にともない，核が細胞質のほぼ中央から細 胞の基底側に移動する ${ }^{42)}$ 。

著者が観察を行なったワニの歯では，内エナメ ル上皮が象牙質の基質形成期に入ると，それ以前 の内エナメル上皮に比してやや細胞の背丈が伸長 するが，まだ低い円柱形で，核は細胞質のほほ中 央もしくは中央よりやや基底側に位置している。 さらに象牙質の基質形成が進むにつれて，内エナ メル上皮の細胞長はわずかながら順次伸長し，そ れにともなって核は 細胞の基底側に位直するよう になる。

また哺乳類においては，内エナメル上皮の背丈 がある程度伸長し，核が細胞の基底側に移動をお こなつたのちに，象牙質の基質形成期に入る ${ }^{69,70) 。 ~}$ すなわち哺乳類では象牙質基質形成期に入る 前 に, 細胞の核が内エナメル上皮の基底端に移動し ている。

したがって，核が細胞の基底側へ移動する時期 に関しては，魚類から両生類，爬虫類にいたるま で，いずれにしても中胚葉における collagen 線 維形成期におこなわれ，哺乳類にいたってはじめ て象牙質基質形成前に核の移動がおこなわれるよ うになることが理解される。しかし，魚類では核 の移動が比較的緩慢に行なわれているが, ワニで は両生類や哺乳類と同様, 核の移動が魚類のそれ に比して短期間に，比較的急速におこなわれてい る。

さらに内エナメル上皮ならびにエナメル芽細胞 の発育にともなう細胞長の変化に関しては, 内エ ナメル上皮の初期状態からエナメル質の石灰化期 に向つて, 細胞が発育伸長し, エナメル芽細胞に 完全に分化をおこすまで細胞長が増加を示すこと は, 魚類, 両生類および哺乳類においてまったく 同一である。

また脇田 $(1974)^{35)}$ と小野 $(1974)^{36)}$ は, 魚類では エナメル質基質の石灰化期になると, 上皮性要素 の周囲に存在する毛細血管が 徐々に外エナメル上 皮をともなってェナメル芽細胞層に陥入しはじめ るために，エナメル牙細胞は背丈の高、領域と低 い領域とが観察されるようになると述べている。 しかし，ワニでは両生類や哺乳類と同様，その 
ような所見はみられない。

一方, ワニでは両生類と同様，象牙質を構成す る collagen 線維の形成期に，哺乳類や魚類にお ける程急速な細胞の伸長はみられない。

しかし哺乳類においては，象牙質基質形成前に すでに内エナメル上皮の背丈がかなり高くなって いる(0)。それに反し, 魚類 ${ }^{35,36)}$ や両生類 ${ }^{42)}$ ならび にワニでは，中胚葉領域における collagen 線維 形成期直前の内エナメル上皮の細胞長は，哺乳類 のそれに比してはるかに短かい。

魚類のエナメル質基質形成期は，哺乳類などの 象牙質基質形成期にほぼ相当し，さらに魚類にお いてエナメル質基質の深層から表層に向って crystal の沈着が進行するエナメル質石灰化期は，哺 乳類などのエナメル質基質形成期すなわちエナメ ル質の石灰化期に相当するものである。したがっ て魚類と哺乳類などでは，エナメル質と象牙質と の差はあれど，同じ collagen 線維形成期に内エ ナメル上皮が最も発育を示し，エナメル芽細胞に 分化をおこし， 細胞長が最大となったのちに，エ ナメル質の crystal が出現することに関しては, 魚類においても両生類，哺乳類などと全く同様で ある ${ }^{35,36) 。 ~}$

また，爬虫類のマムシ毒牙に関する光学顕微鏡 的観察でも，同様な所見が述べられている。

ワニに関する著者の所見では，内エナメル上皮 の初期状態から 象牙質基質形成期ならびにエナメ ル質基質形成期の初期にかけてごくわずかながら 徐々に細胞の背丈を伸長し，エナメル質の基質が ある程度形成されたのちに，細胞の背丈が最長と なる。したがってワニでは魚類，両生類および哺 乳類などに比して芽細胞の最長となる時期が多少 おくれている。

$\mathrm{Kvam}(1958 \mathrm{~b})^{16)}$ もまたワニにおける 所見で芽 細胞が本来の大きさとなる前にしばしばエナメル 質形成が生ずることがあると述べている。

\section{2. 細胞の隣接面構造について}

初期状態の内エナメル上皮細胞における細胞隣 接面の形態や構造に関し, 哺乳類 ${ }^{66,67,70-72)}$, 両生

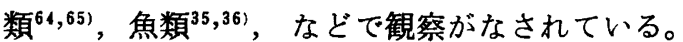
それらの所見を総合すると, 初期状態における内 エナメル上皮の隣接細胞との接着様式には, des- mosomeによるもの ${ }^{35,36,64,68,70-72)}$ と tight junction によるもの ${ }^{35,36,65)}$ とが報告されている。

また内エナメル上皮の隣接面の 細胞膜は隣接の ものと密接していると記載しているもの ${ }^{35,36,64,65}$, 70)のほか， 隣接細胞間が場所によって開大し，そ の領域に microvilli が存在するという報告もみら れる ${ }^{67,68,71,72) 。 ~}$

ワニにおける内エナメル上皮の初期状態では, 細胞相互が近接し, 細胞の隣接面には desmosome が観察される。しかし，内エナメル上皮の初期状 態における desmosome は，いまだ発達の程度が 悪く，しかもその数は少ない。またこの初期の細 胞では tight junction が観察されない。

一条 $(1969)^{70)}$ は，ラットの切歯で観察し，内エ ナメル上皮の初期状態から，細胞の発育によって 背丈が伸長しはじめるとともに，細胞の隣接面に は，部位によって interdigitation を呈する領域 や，また部位によっては細胞間隙が離開し，それ らの領域に細胞小突起が みられるようになるとの べている。さらに象牙質基質形成期になると細胞 の背丈がさらに伸長し，細胞間隙の離開部は順次 消失し，エナメル質基質形成期のエナメル芽細胞 では，隣接細胞膜が互いに平滑な細胞膜で近接し ているが， $3 \sim 4$ 個の細胞が合する細胞偶角部で は細胞膜が入りみだれ，互いに interdigitation を呈する領域と，細胞間隙がわずかに開大し，そ れらの領域にわずかの microvilli が観察される領 域とがみとめられると述べている。また，山 $(1971)^{73)}$ はヒトにおける分化期の所見でもほぼ類 似した結果を報告している。

一方, Smith ら $(1971)^{65)}$ はイモリで観察し，内 エナメル上皮が末分化な時期では隣接細胞間は近 接しているが，象牙質の形成にともなって inter cellular space がみられるようになると記載して いる。

脇田 $(1974)^{351}$ は硬骨魚類 のニザダイで，小野 $(1974)^{36)}$ はイシダイで観察し，エナメル質基質を 構成する collagen 線維が形成されるまでは隣接 細胞相互間は互いに密接しており，エナメル質基 質の collagen 線維の形成期では, 隣接面細胞膜が 比較的平滑な状態で 密接しているとのべている。 しかし細胞偶角部では 細胞間隙がわずかに開大し 
ている場合もみられ，そのような領域では不規則 な microvilli ないしは，それらが interdigitation をなしていると記載している。

さらにエナメル質基質の石灰化期になると，芽 細胞は隣接のものと密接し, interdigitationをな す領域も多く観察されるが, 細胞偶角部などでは, 細胞間隙が増大するとともにそれらの領域には microvilli が観察されるとのべている。

ワニの所見では内エナメル上皮の初期状態から 象牙質基質形成期が近づくにつれて，わずかなが らも背丈が伸長し，順次細胞の形態が短円柱形に ととのってくる。また細胞偶角部などに細胞間隙 の開大がみられるようになり，それらの預域に microvilli が観察されるようになる。

このようにして象牙質基質形成期に入り，象牙 質の石灰化期が近づくにつれ，偶角部における細 胞間隙は増大し，それらの領域における microvilli もやや発達増加する。しかしエナメル質基質形成 期が近づくにつれて細胞間隙が減少し，それにと もなつて順次 interdigitation をなす領域が増し てくる。エナメル質の基質形成期に入ると，細胞 間隙はほとんど消失し，隣接細胞間に interdigitation をなす領域が増大するようになる。

以上のように内エナメル上皮ないしはエナメル 芽細胞の発育にともなう細胞間隙に 関する推移変 化について，哺乳類や両生類あるいは魚類におけ る所見と著者が観察を行なったワニのそれとを比 較対照してみると，内エナメル上皮の初期状態で はすべての動物において同一の所見である。しか し哺乳類とワニでは細胞偶角部における間隙の開 大が早く，象牙質基質形成前にすでに偶角部にお ける間隙の開大が始まっている。一方，両生類で は象牙質基質形成期になってはじめて細胞間隙の 開大がみられ，魚類では象牙質とエナメル質との 差はあれど，いずれにしても両生類と同様，中胚 葉領域における collagen 線維形成期になっては じめて細胞間隙の開大がみられるようになる。

しかしエナメル質の石灰化期におけるエナメル 芽細胞に関しては，すべて大なり小なり細胞間隙 が存在していることは共通している。また細胞の 発育時期に関倸なく細胞間隙には microvilli が存 在していることも共通している。
さらに細胞隣接面における interdigitation に ついては前述したが, desmosome や tight junction などが内エナメル上皮の発育と細胞の伸長に ともなって数と規模が増し，エナメル質の石灰化 期に最も発達を示すことに関しては，ワニにおい ても哺乳類や魚類における所見と同様である。

しかし desmosome や tight junction が発達を

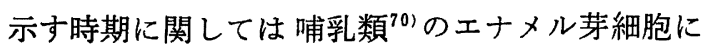
比して魚類 ${ }^{35,36)}$ とワニではともにおくれているよ うに思われる。

\section{3. 細胞質の構造について}

(1) rER について

一条 $(1969)^{70)}$, Pannese (1962) ${ }^{66)}$ は内エナメル 上皮の初期における $\mathrm{rER}$ はいまだ数も少なく, 発達が悪く，配列も不規則であるとのべ，初期状 態の内エナメル上皮には free の ribosome が細 胞質全体に分布しているが，rER の発達の悪いこ とに関しては哺乳類と魚類において意見が一致し ている ${ }^{35,36,66,68-70) 。 ~}$

ワニの歯に関しても内エナメル上皮の初期状態 においては, 従来の他の動物における所見と同様 で差はみられない。

さらに哺乳類や魚類などで内エナメル上皮の背 丈が伸長し，分化をおこすにしたがって，rERの 数が増加し, 発達を示すことが多くの研究者によ ってみとめられている ${ }^{67-70,72,74)}$ 。また哺乳類や魚 類などにおけるエナメル質基質石灰化期のエナメ ル芽細胞では, rER が非常に多く存在し, 一般に 細胞の長軸方向に配列していることが観察されて いる35,36,69,70,72,73,75-79)。

Decker $(1963)^{67)}$ は rER の増加はエナメル芽細 胞への cytodifferentiation を決定づけるものであ るとのべているが, 哺乳類や魚類などでは, 内エ ナメル上皮細胞の伸長と,核の移動ならびに Golgi area の移動と発達のほか, rER の高度な発達が エナメル芽細胞への 分化の特徵の一つとなってい る。

ワニにおいても，エナメル芽細胞へと分化をお こす過程は, 哺乳類や魚類における所見と同様で ある。

しかし， ワニではエナメル質基質形成期に入り やや時期がすぎたのちに，細胞長が最大となると 
ともに, rER がもっとも発達した状態となる。な お，ワニではエナメル質の基質形成が開始された 時期のエナメル芽細胞では, Golgi area ならびに mitochondria など organella の状態からみて, 機能的には，すでにエナメル質基質形成に対して 充分に分化を起こしているものと考える。

(2) mitochondria について

哺乳類と魚類の エナメル質石灰化期以前におけ る内エナメル上皮細胞の mitochondria に関して は, 細胞の分化にしたがってわずかに数を増 すが, 細胞全体に散在していると述べられてい $3^{35,36,70)}$ 。

しかし，エナメル質基質形成期（石灰化期）に おけるエナメル芽細胞に関し，ラットでは mitochondria が核より基底側細胞質に密に集積し, その他の領域にはほとんど観察されないとさ れ69,70,74-80)，またヒトではラットに扔けるような 局在性はみられないと述べている ${ }^{73)}$ 。

一方, 魚類に関して, 脇田はニザダイ ${ }^{35)}$ で, 小 野はイシダイ ${ }^{36)}$ でっエナメル質基質を構成する collagen 線維の形成期に, 芽細胞の伸長にともな って mitochondria の数は増加するが, それらは 細胞質全域に散在しているとし，石灰化期におい ても mitochondria の分布状態は, 前段階とほぼ 同様であるという。

しかし，イシダイでは機能側半細胞質に伸長し た長棈円形のものが数多く観察されるようになる といい, ニザダィでは石灰化期の後半では, 機能 側半細胞質に mitochondria が多少増加を示すが, mitochondria の局在性はみとめられていないと のベている。

ワニでは, mitochondria の分布状態は, 象牙 質基質形成期にいたるまで哺乳類や魚類における それと基本的には同様で，変化はみられない。し かし，象牙質基質形成後期に，核が細胞の基底側 に位置するようになると，徐々に mitochondria が核より機能側細胞質に密集するようになり，エ ナメル質基質形成期では， mitochondria が機能 側における terminal web の基底側領域に局在す る。

また，ワニではエナメル質基質形成期にいたる まで, mitochondria の matrix はやや electron dense な状態を示しているが，基質形成期の末期 で terminal bar が機能端に移動する時期になる と, mitochondria の matrix の density がより 低く，それらが明調に観察されるものが出現しは じめ, 順次前者の mitochondria が減少し, 後者 の mitochondria が増加を示し, ついには前者に 代って後者の mitochondria のみとなり, やがて 局在性も消失し, matrix の明調な mitochondria のみが細胞質に広く散在するようになる。

倉橋 ${ }^{811}$ のラット切歯の所見によると, エナメル 質基質形成の 後期では, mitochondria が 細胞近 心側のみに限局することなく，遠心側にもかなり 多くなると述べている。

さらに哺乳類では, 成熟期になると, エナメル 芽細胞の機能端に infolding の形成がみられ, infolding の基底部に mitochondria が集団を形 成していることがみとめられている ${ }^{81,821 。}$

また魚類に関し, 脇田 ${ }^{351}$ によれば, ニザダイの場 合にはエナメル質の成熟期に入ると， mitochondria が細胞質の機能側にやや多く集積しているこ とが観察されるとのべている。しかし，小野 ${ }^{36)} に$ よると,イシダイでは成熟期においても， mitochondria は機能側に 集積する状態はあまりみと められないという。

したがって，エナメル質の石灰化期に打ける mitochondria の分布状態に関しては，それぞれ かなり異なっている。

絜歯類の切歯でエナメル質基質形成期に mitochondria が 基底端細胞質に 局在性を示すのは, エナメル質基質形成期にエナメル器を通じての物 質導入が盛んであることも関係があると思われ る。

また一方，ワニのエナメル質基質形成期の芽細 胞における mitochondria の分布状態は, 璻歯類の 切歯と魚類における成熟期のものに近い。すなわ ち，ワニでェナメル質基質形成期における芽細 胞の機能側に mitochondria が局在することは, エナメル髄などの上皮性要素の発育が哺乳類のそ れに比して悪いことと，さらにワニでは，後述の ごとくエナメル質基質形成期に，幼若なリボン状 の結晶が沈着する一方, それらの発育増大が哺乳 類や魚類のそれに比して, 光䫓的所見の項で述べ 
たごとく，はるかに急速に進行するため，エナメ ル質基質形成期のエナメル芽細胞は，エナメル髄 からの物質導入，さらにはエナメル質への分泌も さることながら，エナメル質における有機成分な どの吸収や，形成途上のエナメル質から芽細胞人 の物質導入が盛んなことなどにも，何らかの関連 性があるのではないかとも思われる。

また, mitochondria の形態に関して, 魚類で はエナメル質基質の collagen 線維の 形成期で, 細胞の伸長にともない棈円形の mitochondria が 出現し， 細胞の長軸方向に配列するようになり， 石灰化期では長楕円形のものが数多く観察される ようになるとのべている ${ }^{35,36) 。 ~}$

ワニにおいては，象牙質基質形成期の後期で， mitochondria が局在性を示しはじめる時期から 象牙質石灰化期にかけて, 比較的長い mitochondria が増加しはじめ，エナメル質基質形成期では 長楕円形や長杆状のものがさらに増加する。

また，哺乳類においてもヒトでは，エナメル質 基質形成期に mitochondria が増量するとともに， 大きくなることが観察されている ${ }^{73)}$ 。

したがって, mitochondria の形態の変化に関 しては，ワニにおいても魚類やヒトのそれに類似 しているように思われる。しかし，ワニのエナメ ル質基質形成末期にみられるような mitochondria の構造の変化などは，魚類においてもみられない。

(3) Golgi area について

内エナメル上皮が末分化な時期では, Golgi area の発達が悪く，核より基底側の細胞質に位置して いるが，内エナメル上皮が発育伸長し，エナメル 芽細胞に分化をおこし，核が細胞の基底側に移動 するのにともなって, Golgi area が核より機能側 細胞質に移動することがすでに光顕的観察によっ てみとめられている83-85)。

また Golgi complex に関する電顕的観察にお いても，多くの研究者が哺乳類で光顕的観察所見 と同様な所見を得ている。

以上のように，内エナメル上皮の発育伸長によ って，エナメル芽細胞として分化をおこす時期に， Golgi area が核より基底側から機能側細胞質に移 動することに関しては，今や定説となっている。 魚類に関しては， 脇田 ${ }^{351}$ と小野 ${ }^{36)}$ の所見による
と，エナメル質基質を構成する collagen 線維が 形成され始めると，核も細胞犋の中央から基底側 に位置するようになり，それにともない Golgi area もやや発達し，核より機能側で，核に近接 した領域に位置するようになる。さらにエナメル 質基質の collagen 線維の形成期になると Golgi area はやや発達し, エナメル質基質形成期の後半 では, Golgi area が核より機能側細胞質の中央約 $1 / 3$ の領域に存在するようになる。またエナメル質 の石灰化期になると,Golgi area はさらに発達し， 細胞の機能側 $1 / 3$ の領域から，さらに核の基底側 領域まで広範囲にわたって存在するようになる。

ワニにおいても内エナメル上皮の初期状態から 象牙質基質形成期にいたるまでの Golgi area は 発達が悪く，一般に核より基底側細胞質で，核に 近接した領域に位置している。さらに象牙質の石 灰化が基質表層に近づくにしたがって, Golgi area はやや発達を示すとともに, Golgi area の移動が みられ，それらの大部分が核の周囲からさらに核 の機能側細胞質に位置するようになる。

さらにエナメル質基質形成がはじまると, Golgi area がさらに発達し，とくに核の機能側細胞質に 存在する Golgi area の範囲が扡大されてくる。 また，エナメル質基質形成期では，Golgi area が さらに発達し，核の機能側で，核に近接した領域 から，核より機能側細胞質のほぼ中央にまで達す るようになり，このような Golgi area の分布状態 はエナメル質基質形成期の末期まで持続される。

以上のように内エナメル上皮の初期状態から, エナメル芽細胞への分化の過程で, Golgi area が 順次発達を示し，いずれにしてもエナメル質の石 灰化期に, Golgi area が最も発達し, 広範囲にわ たるようになることに関しては，哺乳類や魚類な らびにワニの所見においてもまったく同一であ る。

しかし，ワニではエナメル芽細胞における rER の発達ならびに細胞長が最大となり， Golgi area の分布範囲も最も広くなる時期が, 哺乳類や魚類 のそれに比してややおくれており，ワニではエナ メル質基質形成の開始からやや時期がすぎたのち にそれらが最も発達した状態となっている。

また哺乳類の基質形成期では，Golgi area で分 
泌顆粒が形成されることが認められ60,70,72,74-86), さらに分泌顆粒のほかに multivesicular body や 種々の lysosome ${ }^{66,70,74)}$ などの存在も記載されて いる。

魚類においても，エナメル質の石灰化期では， Golgi complex がもっとも発達を示し, 分泌顆粒 ならびにその他の顆粒状構造物の形成が 非常に盛 んであるというう5,36)。

一方ワニにおいてもェナメル質基質形成期のエ ナメル芽細胞では 哺乳類や魚類における所見と同 様 Golgi complex がもっとも発達し, Golgi lamelle が比較的長く, 細胞の長軸方向に配列して いる。また Golgi area では哺乳類や魚類におけ る場合と同様, 通常の vesicle や coated vesicle などの形成が多く，さらに分泌顆粒およびその他 の顆粒状構造物の形成が盛んである。

sER に関しては, Katchburian ら (1972) ${ }^{72)}$ 細胞の分化期でわずかに出現し，基質形成期では sER は rER とともに, Golgi succule に接して いるとのべている。

さらに脇田 ${ }^{35)}$ と小野 ${ }^{36)}$ は魚類に関して, エナメ ル質の collagen 線維形成期から sER が Golgi complex の近くに管状の交錯した状態で観察され ると記載し，さらに sER は Golgi lamelle や rER と連絡しているとのべている。

なおワニにおいても $\mathrm{sER}$ が象牙質基質の形成 がはじまるころから徐々に発達し，さらに Golgi area が 機能側へ移動し Golgi lamelle の長さが 増大するにともない, Golgi area における sER も発達増加する。

またエナメル質基質形成期に入ると, Golgi area の分布範囲が 拡大され, Golgi lamelle は比較的 長くなり, 各種 vesicle, 分泌顆粒その他の顆粒状 構造物が増加を示し, Golgi area の sER も魚類 と同様に広範囲に，しかもそれらが不規則に分枝 して全体として複雑な網状に配列するようにな る。また sER は Golgi lamelle や rER, とくに rER との連絡箇所が増し, 随所で移行する状態が 観察されるようになる。

このように Golgi area の分布範囲の 拡大, Golgi lamelle の 発達, 各種 vesicle や分泌顆粒 その他の顆粒状構造物の増加と, sER の発達はつ
ねに相まっている。そのさい分泌顆粒は Golgi area 全域に観察されるがそれらが，とくに sER が多、領域に出現している状態が 非常に多く観察 される。したがって魚類における所見と同様に分 泌顆粒はワニにおいても $\mathrm{sER} て ゙$ 形成されるもの と思われる。

以上のように魯類から 哺乳類にいたる各種動物 の Golgi area に関する所見を比較検討すると, Golgi area の移動ならびに発育時期や発育状態な どについては動物の種類によって多少時期的にず れがみられ，また Golgi area で新生される顆粒 状構造物などの種類や量などについても，動物に よって異なる状態もみとめられる。

しかしいずれにしてもエナメル芽細胞の伸長な らびに rER の発達と Golgi area の分布範囲の 拡大や Golgi complex の発達が相まっており， それにともなって vesicle や各種顆粒状構造物そ の他の産出が盛んになることに関しては，各種動 物において共通している。

\section{（4）顆粒状構造物その他について}

象牙質基質形成前の内エナメル上皮において も，哺乳類や両棲類では，それらの細胞質に multivesicular body ${ }^{67,70)}$, lipid ${ }^{68,70)}$, dense な vesicle $^{71)}$, lysosome ${ }^{72)}$,など 種々の 顆粒状構造物 の存在が観察されている。しかし象牙質基質形成 前の内エナメル上皮では細胞質における顆粒状構 造物はまだ一般に少ないといわれている。

また魚類におけるエナメル質基質を構成する collagen 線維の 形成前の内エナメル上皮に関し て，脇田 ${ }^{35}$ によればニザダイでは限界膜に囲まれ た内部に比較的 density の低、微細な顆粒状構造 物が均質な状態で観察されるもののほか， グリ コーゲン顆粒が観察されるとのべている。これら のグリコーゲン顆粒は電顥的にはグリコーゲン粒 子の集合体で構成された粗大顆粒で，光顕的には PAS 陽性であるという。これらのグリコーゲン顆 粒は内エナメル上皮のごく初期の状態をのぞき， 中胚葉領域にエナメル質基質を構成する collagen 線維が形成される以前の時期から細胞に出現し， エナメル質の石灰化期を通じ 細胞質に比較的多数 観察され，エナメル質の成熟期に入ると消失する と記載している。なお，山 $(1971)^{73)}$ はヒトのエナ 
メル芽細胞の分化期を通じ，グリコーグンが集合 性，あるいはび慢性に分布しているとのべている。

しかし同じ魚類でも小野 ${ }^{36)}$ が観察をおこなった イシダイにおいては，このようなグリコーゲン顆 粒は観察されず，基質形成期以前の内エナメル上 皮には, 顆粒状構造物がきわめて少なく, lysosome や vacuole がわずかにみとめられるのみで，哺 乳類のそれとあまり変化はみとめられないとのべ ている。

著者が観察をおこなったワニにおける象牙質基 質形成前の 内エナメル上皮では，とくに Golgi area に lysosome などの顆粒状構造物や multivesicular body なども観察されるが，その数は少 なく，一般に哺乳類などにおける同時期の細胞の 状態とあまり大きな差はみられない。

しかしワニにおいては，ニザダイにみられるよ うなグリコーゲン顆粒は，エナメル質形成の全期 間を通じて出現しない。

さらに象牙質の基質形成期におけるいわゆる preameloblast の顆粒状構造物に関し，哺乳類で は lysosome 様の顆粒状構造物のほか，エナメル 質基質形成期に多く出現する分泌顆粒が，この時 期においてすでに観察されている70,71,69)。

魚類のエナメル質基質を構成する collagen 線 維の形成期の細胞については, 脇田 ${ }^{351}$ がニザダイ における所見で，前述のグリコーゲン顆粒のほか density の低い比較的大型円形の 顆粒（type 1) とやや density の高い長円形の顆粒 (type 2) の 出現について記載し，これらの二種の顆粒は基質 形成が完了すると消失するとのべている。

一方イシダイにおける小野 ${ }^{36)}$ の所見では，エナ メル質基質の collagen 線維の 形成期に入ると, 細胞質に PAS 陽性の大型顆粒が出現し, collagen 線維の形成期を通し，さらにエナメル質の石灰化 期の初期まで細胞質に出現すると述べている。そ のほか lysosome 様の顆粒状構造物も哺乳類のそれ と比してはるかに少ないが, Golgi lamelle やrER の断端が震状に膨大する状態が 非常に多く観察さ れ，物質合成活動が盛んであるとのべている。

哺乳類におけるエナメル質の 基質形成期すなわ ち石灰化期では, 芽細胞の細胞質に electron dense な分泌顆粒の存在が みとめられている ${ }^{68-70,75,78,86,}$
88-92)。また分泌顆粒のほか lysosome, multivesicular body などの顆粒状構造物あるいは各種の vesicle などが多数出現することが多くの研究者 によって観察されている ${ }^{68-70,75,78,86,88-93) 。 ~}$

脇田 ${ }^{35)}$ はニザダイにおけるエナメル質の石灰化 期に执いては, Golgi complex がその時期にもっ とも発達を示すことは哺乳類と同様で, 各種 vesicle の形成が非常に盛んになり，Golgi lamelle の限界膜が円形襄状に膨大し，顆粒状構造が形成 されていることなどを観察している。

一方小野 ${ }^{36)}$ によると，イシダイのエナメル質石 灰化期では分泌顆粒のほか multivesicular body その他の顆粒状構造物が多く出現し，とくに顆粒 状構造物は種類も多く大きさもまちまちで，同種 のもの，異種のもう相互に接着融合が多く観察さ れるとのべている。

ワニでは象牙質の基質形成期の初期では, Golgi area の発達がいまだあまりょくないこともあっ て, lysosome などの顆粒状構造物や multivesicular body などが Golgi area にわずかに観察さ れる程度で，それ以外の領域にはまだ非常に少な い。しかし，象牙質基質の石灰化期に近づくに れ, Golgi area の発達にともない, Golgi area もしくはその近傍に大小さまざまな lysosome 様 の顆粒状構造物や multivesicular body などが多 く出現するようになり，順次数が増加し，象牙質 基質の石灰化期になると, 分泌顆粒も出現し始め る。また象牙質基質形成期に出現する lysosome 様の顆粒状構造物はおおよそ二種 $\left(\mathrm{L}_{1}, \mathrm{~L}_{2}\right.$ 顆粒) に分類され，両者の顆粒はともに大きさがまちま ちであるが，量的には $\mathrm{L}_{1}$ 顆粒の方が $\mathrm{L}_{2}$ 顆粒に 比してはるかに多い。

また $\mathrm{L}_{1}, \mathrm{~L}_{2}$ 顆粒はエナメル質基質形成期に入 ると， $\mathrm{L}_{1}$ 顆粒に比して $\mathrm{L}_{2}$ 顆粒が多くなり，さ らにエナメル質基質形成期の初期から 芽細胞の背 丈が伸長するにともなって, $\mathrm{L}_{1}$ 顆粒は順次減少 消失し， $\mathrm{L}_{2}$ 顆粒のみとなる。なおこれらの $\mathrm{L}_{2}$ 顆粒はエナメル質基質形成の末期にいたるまで引 き続き出現する。

またエナメル質基質形成の末期になると， $\mathrm{L}_{2}$ 顆 粒以外に，所見の項で述べたごとく Lm 顆粒が 出現し順次増加してくる。 
またそのほか，ワニのエナメル質基質形成期の 芽細胞には，限界膜に囲まれた内部に，針状ない しは薄い板状の結晶様構造物がほぼ放射状に密に 配列している顆粒状構造物がまれに観察される。

田熊ら (1975) ${ }^{87)}$ はラットの切歯先端の 骨様象牙 質の形成に関与する細胞において 針状結晶の集団 からなる球状体について観察している。しかし， 他の動物のエナメル芽細胞においては，この様な 顆粒状構造物に関する記載はみとめられない。

また一方，ワニにおいてはイシダイに関する小 野 ${ }^{36)}$ の所見にみられるような, PAS 陽性顆粒は エナメル質基質形成期を通じて出現しない。

また魚類に関する脇田 ${ }^{35)}$ ，小野 ${ }^{36)}$ の所見による と，エナメル質基質を構成する collagen 線維の 形成がはじまると, 細胞質に杆状体が観察される。

ワニのエナメル芽細胞においてもこれらの杆状 体が観察され，ワニでは象牙質基質形成後期で， 象牙質基質の石灰化が はじまる直前から出現しは じめ，エナメル質基質形成の末期にいたるまで観 察されている。

小野 ${ }^{36)}$ はイシダイにおける杆状体は数が多く警 曲や蛇行，さらにYの字形その他分枝を示すもの が多いと述べているが. ワニにおいては脇田 ${ }^{351} の$ ニザダイにおける所見と同様, 杆状体の数はイシ ダイのそれに比べて少なく，分枝の状態も少ない。 また脇田 ${ }^{35)}$ と小野 ${ }^{36)}$ はともに杆状体が Golgi area で形成されると述べている。著者のワニにおける 所見でも杆状体がつねに，Golgi area に多く観察 されることからみて，杆状体は Golgi areaにて 形成されるものと思われる。

ワニにおいても魚類における所見 ${ }^{35,36)}$ 之同様, エナメル芽細胞に centriole が観察され, 象牙質 基質形成以前からエナメル質基質形成期を通し, Golgi areaに centriole が $1 \sim 2$ 個観察される。 その際 centriole は Golgi area でも核の近傍に 観察される場合が多い。

各種動物の内エナメル上皮の初期状態から，石 灰化期までのエナメル芽細胞における顆粒状構造 の出現状態について，比較検討をおこなうと，魚 類においてはエナメル質基質の collagen 線維形 成期を中心にして，グリコーゲン顆粒や PAS 陽 性顆粒などの特殊な顆粒が 非常に多く出現してい
るのに反し， ワニではそのような顆粒は出現して いない。

またエナメル質の石灰化期の芽細胞に 分泌顆粒 が多く出現することに関しては，各種動物に共通 しているが，それらの分泌顆粒が出現しはじめる 時期について，ワニでは哺乳類と同様に比較的早 く, エナメル質の石灰化期前に出現しはじめてい るのに反し，魚類における所見では，ワニや哺乳 類のそれよりおそく石灰化期になって出現してい る。

さらに，その他の顆粒状構造物の種類や出現状 態ならびに出現時期などについては各動物によっ てそれぞれ異なっている。

\section{4. 機能端領域の変化について}

\section{（1）エナメル芽細胞機能端の形態と硬組織形}

\section{成について}

A）象牙質基質形成前の内エナメル上皮

中胚葉領域に collagen 線維が形成されるまで の内エナメル上皮機能端細胞膜は哺乳類, 両生類, 魚類などいずれも平滑で, basement membrane を介して歯乳頭に扔ける未分化の象牙芽細胞に接 していることが観察され，さらに内エナメル上皮 の初期状態から 機能端細胞膜には pinocytosis が おこなわれていることがみとめられている ${ }^{35,36,63,}$ $65,70)$ 。

内エナメル上皮機能端領域の terminal bar は 哺乳類および魚類の初期状態の内エナメル上皮で は観察されないといわれている35,36,70)。

ワニにおいても象牙質基質形成期前の機能端領 域の所見は, 魚類や両生類ならびに哺乳類に関 するそれらの所見と全く同様で差はみとめられな い。

B）象牙質基質形成期の内エナメル上皮

哺乳類に㧍いては象牙質基質形成がはじまる以 前で，内エナメル上皮の背丈がやや伸長し，核が 細胞の基底側に移動した時期に，すでに機能端に terminal bar が出現しはじめる。また，象牙質基 質形成期には terminal bar が 発達を示すととも に，細胞の機能端からわずかにはなれた位置に後 退し, これらの terminal bar の領域からさらに 細胞体がやや象牙質側に伸び出し，将来のトーム スの突起の形成に入る。しかし象牙質基質形成期 
においては, それらの発育も悪く, 短かいと記載 されている70)。さらにこの時期における細胞の象 牙質面細胞膜は象牙翼基質最表層に位置する basement membrane に近接しているが， 細胞膜に わずかの繇入が多くみられているようになり凹凸 を示すといわれている70)。

魚類ではエナメル質基質を構成する collagen 線維の形成期に入ると, 急速に基質の形成が進み, それにともなって細胞の背丈も急速に 発育伸長 し， 細胞が長円柱形となるにしたがって機能端に terminal bar が観察されるようになる。さらに terminal bar の発達と, 細胞の伸長にともない terminal bar の位置が後退し，それより機能側の 細胞体が伸長し，トームスの突起が形成される。 しかしこれらのトームスの突起の機能端細胞膜は 平滑で, basement membrane を介してェナメル 質基質を構成する collagen 線維に接していると 記載されている ${ }^{35,36) 。 ~}$

また小沢 $(1972)^{94)}$ によると，哺乳類に扔ける所 見で末分化の内エナメル上皮では， basal lamina に接する細胞表面は平滑で， half desmosome で 結合しているが，分化にともない細胞表面は凹凸 を呈するようになり，ついには多数の小突起を形 成して， basal lamina を貫くようになる。さらに 象牙質の石灰化が開始する時期には，この突起形 成はさらに著しくなり, basal lamina は不明瞭と なるという。

また basement membrane が消失する時期に 関しその他哺乳類については， Reith $(1967)^{68)}$ が ラットの臼歯を用いて観察し，エナメル芽細胞の 分化をおこし始める時期で，象牙質の石灰化直前 に basement membrane が消失すると述べてい る。Takuma (1967) ${ }^{95)}$ はヒト胎児で basal lamina は predentin の石灰化開始後すぐに消失すると記 載している。

両生類では Smith ら (1971) ${ }^{65)}$ が urodele の apical region には enamel formation をみとめ, エナメル質の crystal が形成され始めると basement membrane が消失するという。

魚類に関して脇田 ${ }^{35)}$ と小野 ${ }^{36)}$ はエナメル質基質 を構成する collagen 線維に crystal が 沈着する いわゆる石灰化期になると，エナメル茅細胞の機
能端細胞膜に細胞小突起ならびに 細胞膜彎入がみ られるようになり，それにともなって basement membrane は順次不明膫になると述べている。

一方ワニにおいても内エナメル上皮の機能端細 胞膜面に half desmosome が観察されるが, 象牙 質基質形成前の内エナメル上皮では，機能端細胞 膜における half desmosome は形態がやや不明瞭 で，その数も少ない。しかし象牙質基質形成がは じまり, 時期が進むにつれて, 内エナメル上皮機 能端における half desmosome は徐々に明瞭とな り，その数も順次増加を示す。

象牙質の基質形成が 開始される時期になると， 細胞の 機能端に 先がけて, 細胞の 基底端領域に terminal bar が形成されはじめる。

象牙質基質の 形成が進むにつれ, 細胞の機能 端に比較的近い隣接面に，他の隣接面に比して 発達した desmosome もしくは tight junction が 出現しはじめ，それらは時期が進むにつれて順次 明確となってくる。さらに，象牙質基質の石灰化 期が近つ゚くにつれ，隣接細胞間における離開部が 拡大され，それにともない細胞の機能端隣接面に terminal bar が出現しはじめる。

しかし，この時期における terminal bar は一 般にまだ発育がわるく， terminal web の形成は みられない。

一方, 機能端に terminal bar の形成がはじま る頃になると， 内エナメル上皮の機能端細胞膜 は，部分的に凹凸を示すようになり，やがて不規 則な形態の細胞小突起が突出しはじめ, basement membrane を貫いて象牙質基質内に侵入するよう になる。したがって, 細胞小突起が突出した部分 では, basement membrane が消失する結果とな る。

さらに象牙質の石灰化が 象牙質基質の表面にま で進行する頃には, それらの細胞小突起の数は増 加し, basement membrane は消失していく。ま た細胞小突起の増加と basement membrane の 消失にともない，細胞膜彎入がみられるようにな る。

この時期では, 象牙質の石灰化が象牙質最表層 にまで接近しているが, 象牙質基質の表面は細胞 小突起と細胞膜彎入の外形に対応してかなり凹凹 
を示す結果となる。

またこの時期の 細胞膜彎入部内の collagen 線 維は数が減少し，象牙質基質表層に位置する比較 的細い collagen 線維は消失し，その下層に位置 する比較的太い線維が 細胞膜第入部に侵入する状 態となる。

以上のことから, basement membrane の消失 と，細胞小突起と細胞膜彎入が生ずる時期では， 象牙質基質表層の collagen 線維 は何らかのかた ちで吸収されているのではないかと思われる。ま た, 山 $(1971)^{73)}$ は, ヒトの材料で観察し, 細胞小 突起ならびに細胞膜紗入の出現に関して，ほぼ同 様な所見をのべている。

石灰化した象牙質の表面に，未石灰化の collagen 線維が，とくに細胞膜彎入部などにまばらに 残存している間に，細胞膜彎入部その他の機能端 細胞膜外にすでに amorphous material が出現し はじめ，基質の collagen 線維の消失と，象牙質 の石灰化がその表面に達するのとほぼ時を同じく して象牙質表面に，エナメル質の crystal が沈着 しはじめる。

このようにしてェナメル質の結晶が象牙質表面 に沈着し始めると，内エナメル上皮の機能端では， 細胞小突起や細胞膜彎入が減少消失していく。

また一方では象牙質の石灰化が近ゔくにつれ， 細胞の機能端隣接面に terminal bar が観察され るようになる。これらの terminal bar は，最初 細胞隣接面で最も機能端によった位置に出現する が，多数の細胞小突起ならびに細胞膜彎入の形成 とさらにエナメル質の結晶の沈着しはじめる頃に なると, terminal bar は徐々に機能端から基底側 方向に向かって後退し始める。

C）エナメル質基質形成期のエナメル芽細胞 エナメル質の幼若な crystal がわずかに出現し 始めた時期では，細胞膜がごくわずかに，しかも 不規則な形態で突出し， あるいは細胞膜がわずか に陥入している状態もみられ，機能端の細胞膜面 は一般に不規則な形態を示す。しかし，エナメル 質の crystal の沈着がやや進行すると，機能端細 胞膜は比較的平滑な状態となる。

またエナメル質の基質形成期に入ると, terminal bar はその位置の後退にともない，さらに発
達し， terminal web も順次発育する。それにと もなって terminal bar より機能端における隣接 面には，amorphous material が出現し，それら は機能端細胞膜外に出現している amorphous material と連絡している。

さらにエナメル質の基質形成が進むにつれ，芽 細胞は順次伸長し，それにともない desmosome や tight junction の発達とともに，機能側におけ る terminal bar ならびに terminal web は一層 発達を示す。また terminal bar の移動にともな い機能端細胞膜面に 再び管状の 細胞膜彎入が出 現し，それらの領域も amorphous material によ って密にみたされる。なお，哺乳類のエナメル質 基質形成期におけるトームスの突起細胞膜におい ても細胞小突起や不規則な 形態の細胞膜彎入がみ とめられる ${ }^{48,70,73) 。 ~}$

以上のようにしてェナメル芽細胞の細胞長が最 大となると, terminal bar の位置は機能端からわ ずかにはなれた位置に固定され，それ以上の後退 はなく，しかも terminal bar ならびに terminal web は最も発達した状態となり，エナメル質基質 形成の最盛期に入る。細胞機能端におけるこのよ うな状態は，以後エナメル質基質形成末期にいた るまで持続される。しかし，将来のエナメル質全 幅の形成が完了する頃になると，機能側の terminal bar は再び細胞の機能端へ移動する。それ にともなって, terminal web も順次不明膫とな り,やがて消失していく。また細胞膜彎入の数も減 少し，エナメル質の基質形成はすべて完了する。

哺乳類においてはェナメル質の基質形成期にト ームスの突起が発達し，その先端がエナメル質基 質内に侵入していることが多くの研究者によって みとめられている68,70,73,81,88,91,93,96)。

両生類では Smith ら $(1971)^{65)}$ がイモリの歯で 観察し，トームスの突起は存在しないとのべ，さ らに爬虫類に関しては Weil ら(1970) ${ }^{97)}$ がヤモリ やトカゲを用い，機能端にはトームスの突起が存 在しないとのべている。しかし，Poole (1957) ${ }^{14)}$ によればトカゲ (Agama articollis) では，エナ メル質基質形成期にトームスの突起が出現すると 述べている。

また魚類に関しては脇田 ${ }^{351}$ と小野 ${ }^{36)}$ がそれぞれ 
ニザダイとイシダイについて観察し，ともにエナ メル質基質を構成する collagen 線維の 形成期に 細胞の伸長にともなって terminal bar が発達す るとともに, terminal bar より基質側に向って細 胞体が突出し，それらが哺乳類におけるトームス の突起に相当するものであると述べている。しか し魚類におけるこれらのトームスの突起は，基質 形成が完了するとともに順次縮少消失すると記載 している。

以上のように，哺乳類では象牙質基質形成期前 に terminal bar が出現し始め, エナメル質の 石灰化期には terminal bar が最も発達を示し, terminal bar の位置から機能端細胞質が伸長して トームスの突起が形成されている70)。ワニにおい ても，エナメル質基質形成期に terminal bar が 最も発達した状態になる。しかし terminal bar のわずかな後退によって機能側細胞質領域がやや 伸長するが, トームスの突起の形成にはいたらな い。

したがって，魚類のエナメル質基質の collagen 線維の形成期を哺乳類や爬虫類における象牙質基 質の collagen 線維形成期にあてはめて比較検討 すると, terminal bar が形成されはじめる時期は 哺乳類が最も早く, ワニと魚類においては哺乳類 よりややおくれ, collagen 線維の形成期に出現し はじめている。

また terminal bar が最も発達する時期には， ともに細胞長が最大となり，これに関しては魚類 から哺乳類にいたるまでほぼ一致している。

さらに魚類におけるトームスの突起はェナメル 質基質の collagen 線維形成期にのみ出現し，石 灰化期には存在しないことからみて，哺乳類など におけるトームスの突起と機能的に全く異なる意 義を持つものと思われる。また，哺乳類ではトー ムスの突起尖端部の形態にしたがって，小柱の形 態が決定されると記載されている70)。ワニではエ ナメル質基質形成期にわずかに terminal bar が 後退するものの， いまだ哺乳類にみられるような 典型的なトームスの突起の 形成にはいたらないた めに，哺乳類のエナメル質と異なり，小柱が形成 されない $17,49,52,53)$ もと思われる。

また，魚類ではエナメル質の基質を構成する collagen 線維の形成が将来のエナメル質の全幅に 達すると，その深層から表層に向ってエナメル質 の石灰化が進行する関係上，哺乳類やワニなどと 時期的その他の条件が多少異なるが，魚類におい てもエナメル質の石灰化が表層にまで接近する と, 細胞小突起が出現し，それにともなって基質 表面に位置する basement membrane が消失し ている。

したがって魚類のエナメル質石灰化期を哺乳類 やワニなどの象牙質の石灰化期にあてはめて考え ると，どちらにしても石灰化が表層に接近した時 期に細胞小突起が多数出現し，それにともなって basement membrane が消失していることから， これらの現象に関しては哺乳類やワニと魚類とが 基本的には同様である。

\section{（2）機能端における細胞質の構造について}

前述のごとく哺乳類と魚類では細胞機能端にお ける terminal bar の出現時期, あるいはトーム スの突起の形成時期が異なっているが，機能端領 域における細胞質に関する哺乳類 ${ }^{70)}$ と魚類 $\left.{ }^{35}, 36\right) の$ 所見では，ともに terminal bar が形成されると， 細胞質における rER や mitochondria は, terminal bar の位置で消失し，それより機能端細胞質 においては free の ribosome が観察されるほか 非常に 微細な 粒子状構造が 多く観察される以外 に, rER や mitochondria はほとんど観察され ないと記載されている。

また魚類の所見で, 脇田 ${ }^{35)}$ と小野 ${ }^{36)}$ はエナメル 質基質の collagen 線維の 形成期に 出現するトー ムスの突起細胞質には tube 状構造が 観察され, それらの tube 状構造には比較的太いものとやや 細いものとが観察されるとのべている。

これらの tube 状構造はエナメル質基質の collagen 線維の形成が完了し, トームスの突起が減 少するにしたがって順次不明瞭となり，消失する という。

ワニにおいては terminal bar が出現する時期, ならびに，トームスの突起が形成されないにして も, terminal bar が機能端からわずかにはなれた 位置に固定される時期などに関しては，哺乳類や 魚類のそれと時期が多少異なり，哺乳類のそれに 比してやや時期がおくれている。 
しかし terminal bar が形成されたあと， mitochondria が細胞の機能側領域に局在性を示すこ ととそその領域には $\mathrm{rER}$ が少ないことなどにも 多少関連があるが，細胞質における rER ならび に mitochondria などは terminal bar の位置で 大部分消失し，それより機能端の細胞質には free の ribosome がわずかに存在し，さらに常に微 細な線維状構造が密に存在するほかは, rER や mitochondria はあまり観察されない場合が多い。 それらの状態に関しては哺乳類や魚類における所 見と基本的には差はみられない。

さらに哺乳類や魚類ならびに著者が観察をおこ なったワニにおいても，エナメル質の crystal の 沈着期におけるエナメル芽細胞の 細胞質ならびに 機能端細胞質などに分泌顆粒が 多数出現すること に関しては前述の通りである。

しかしそれらの分泌顆粒が 機能端細胞質に出現 しはじめる時期は，哺乳類では象牙質の基質形成 期 $^{70)}$ ，魚類ではさらにおくれてェナメル質の crystal の沈着期 ${ }^{35,36)}$ とされている。一方ワニで は，これらは象牙質の石灰化が象牙質基質の表層 に接近した時期，すなわち象牙質の石灰化期に相 当している。したがって分泌顆粒が細胞の機能端 細胞質に出現する時期は，ワニでは哺乳類のそれ よりごくわずかにおくれている。しかしいずれに しても分泌顆粒が エナメル質基質形成前にすでに 出現していることに 関しては哺乳類と同様であ る。一方，魚類ではェナメル質の石灰化期に入っ たのちに分泌顆粒が出現している。

また 内エナメル上皮の初期状態から，象牙質基 質，もしくはエナメル質基質を構成する collagen 線維形成期の 機能端細胞膜に pinocytosis が観察 され 機能端細胞質に pinocytosis による coated vesicle が観察されることに関しては，ワニにお

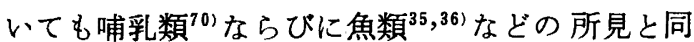
様である。

エナメル質の石灰化期すなわち 哺乳類に関して は，トームスの突起が 形成されている時期に相当 するが，哺乳類や両生類ならびに魚類におけるト 一ムスの突起細胞膜には, pinocytosis が盛んにお こなわれていることがみとめられ ${ }^{35,36,63,70,72) ， ま ~}$ た哺乳類のエナメル質石灰化期におけるトームス
の突起細胞質に coated vesicle が存在することも 多くの研究者によってみとめられている ${ }^{68,70,72,74,}$ ${ }^{86,94)}$ 。そのほか魚類の石灰化期におけるエナメル 芽細胞の機能端細胞質においても coated vesicle が観察されている ${ }^{35,36) 。 ~}$

これらの所見に関しては，ワニにおいてもトー ムスの突起の有無の相異はあるが，哺乳類ならび に魚類における所見とまったく同様である。

哺乳類では，基質形成期におけるエナメル芽細 胞に分泌顆粒が多数出現するとともに，細胞膜外 に amorphous material が出現し, crystal が形成 されることから, amorphous material は enamel の precursor であると考えられている68-70,77-79,86, $88,90,91,93,98-100$ )

ワニにおいても象牙質基質の石灰化が基質の表 層に近接し，細胞の彎入部などに象牙質表層に残 存している collagen 線維の数が減少した 時期以 後，エナメル質基質形成期を通じ，芽細胞の機能 側における terminal barよりエナメル質基質側 の隣接細胞間隙，ならびに細胞膜彎入部その他の 細胞膜外に amorphous material が観察される。

また amorphous material が密に集積している 機能端領域の細胞間隙ならびに 細胞膜彎入部にお いても， coated vesicleによる pinocytosis が盛 んにおこなわれている。

そのほか哺乳類とワニでは，エナメル質の石灰 化期の terminal barより機能端細胞質にはトー ムスの突起の有無に関係なく，微細な tube 状構 造が観察されるが，魚類ではエナメル質基質の collagen 線維形成期においてトームスの突起が存 在する時期に，それらの細胞質内に哺乳類やワニ と同様な tube 状構造が観察される。しかしトー ムスの突起が消失するにともなってそれらの構造 は消失し，エナメル質の石灰化期における芽細胞 の機能端細胞質には tube 状構造はもはや存在し ない ${ }^{35,36)}$ 。

以上のことからワニにおけるエナメル質基質形 成にともなう細胞機能端における 細胞質の構造に 関しては，エナメル質基質形成期にトームスの突 起の形成がみられないことをのぞき，哺乳類のそ れと基本的には大きな差はみられないものと思わ れる。 
魚類や哺乳類と爬虫類のワニにおける所見を総 合的に比較してみると，魚類ではエナメル質の石 灰化に先だち，中胚葉領域にエナメル質の基質を 構成する collagen 線維が 形成されたのちに, エ ナメル質の石灰化が生じる。これらの現象が哺乳 類とまったく異なる点である。それに反して，ワ ニでは哺乳類とまったく同様に，エナメル質の結 晶の沈着に先だって, 単に amorphous material が密に出現するのみである。これらの点が魚類の エナメル質形成とワニや哺乳類のそれと最も異な る点である。

また魚類ではエナメル質基質の collagen 線維 の形成が完了するまでの間に，芽細胞が分化を起 こし，最大長となったのちにエナメル質の石灰化 が始まる。

一方，ワニと哺乳類では象牙質の基質形成があ る程度進行したのち，さらに象牙質の石灰化が開 始され, 石灰化が基質表面に達し, エナメル質の 石灰化が始まるまでの間にエナメル芽細胞が伸長 し，分化を起こす。

したがって，エナメル芽細胞が細胞長の伸長な ど分化をおこす過程を比較すると，魚類のエナメ ル質基質を構成する collagen 線維の 形成期は, ワニと哺乳類におけるおおよそ象牙質基質の collagen 線維の形成期に相当する。

ワニの場合にはエナメル芽細胞が分化をおこす 過程で, 細胞の伸長, 発育が魚類や哺乳類のそれ に比して，かなり緩慢である。また細胞長の伸長 がはじまる時期，あるいは核と Golgi area の移 動時期，さらには機能側における terminal bar の出現時期などが，哺乳類や魚類のそれに比して 全般的に遅れている。

これらの現象は, 哺乳類と魚類のエナメル芽細 胞が，超円柱形となり細胞長が非常に長くなるの に反し，ワニでは，それらに比して細胞長が比較 的短かいことに多少なりとも関連性があるものと も思われる。

機能側に terminal bar が出現しはじめる時期 は, 哺乳類の方が魚類より早いようにも思えるが, 機能側の terminal bar の発達は, 魚類の場合, エナメル質基質の collagen 線維形成期にトーム スの突起が形成されるために，哺乳類に比べては
るかに急速である。一方，哺乳類とワニでは，エ ナメル質の石灰化期に terminal bar が最も発達 を示した状態となる。

しかし 哺乳類では，エナメル質の石灰化期にト 一ムスの突起が発達しているのに反し， ワニで は, terminal bar が機能端からやや後退し, terminal bar の位置からわずかに細胞が突出を示す が，トームスの突起の形成にはいたらない。

また，それに関連し，terminal bar が細胞の機 能端から後退しはじめる時期は，ワ二の方が哺乳 類よりやや遅れている。

哺乳類ではトームスの突起の先端が 形成途上の エナメル質基質内に侵入し，それらが物質輸送の ほか小柱形成を誘導しているといわれているが, ワニではトームスの突起の形成がみられないた め，エナメル質には小柱が形成されず，無小柱エ ナメル質となるものと思われる。

一方, 魚類のエナメル質石灰化期では, トーム スの突起がすでに消失しており，機能端の terminal bar も発育が低下している。魚類のトーム スの突起は, エナメル 質基質の collagen 線維形 成期に出現するもので，エナメル質の石灰化期に はすでに消失しているため，魚類におけるトーム スの突起は，機能上哺乳類のトームスの突起にみ られるような小柱の形成に関与するものでなく， 物質輸送にのみ関連しているものと思われる。

ワニなどでは象牙質の 石灰化が基質表層に近づ くにつれ，芽細胞の機能端細胞膜には細胞小突起 などが出現し，それにともなって基質表層に位置 する basement membrane が消失している。

しかし魚類では，エナメル質の石灰化が表層に 近づいた時期に，ワニや哺乳類と同様，芽細胞機 能端に細胞小突起が出現し, basement membrane が消失している。

したがって，魚類において， basement membrane が消失する状態は，エナメル質の石灰化後 期にみられるもので，それらの状態はワニや哺乳 類における象牙質石灰化期のそれに相当してい る。

また，哺乳類のトームスの突起と魚類のそれが 出現する時期は異なるが，いずれにしてもト一ム スの突起細胞質における tube 状構造などの出現 
その他は，両者間に基本的な差はみとめられな い。さらに, ワニにおいてもトームスの突起の形 成はみられないが，エナメル質石灰化期における 芽細胞の機能端細胞質の構造は，魚類および哺乳 類のそれと基本的には同様である。

さらに，魚類，哺乳類およびワニのエナメル質 石灰化期における芽細胞では，出現する顆粒状構 造物などに関しては，それぞれ多少の差はあるが， rER や Golgi area の状態など本質的な差はみら れず，ともに物質合成が盛んである。

エナメル芽細胞の 分化の過程における形態と構 造の推移について比較検討すると, 爬虫類のワ二 では，魚類の状態と類似した点もみられるが多少 異なる点もみられ，基本的にはむしろ哺乳類のそ れと類似した点が多い。したがって以上の結果を 総合すると, 爬虫類のワニは比較発生学的に中胚 葉エナメル質といわれる魚類から哺乳類への移行 を示している。

\section{結論}

ワニ（メガネカイマン）の歯胚を材料とし， 内 エナメル上皮の初期状態から，エナメル質基質形 成期までのエナメル芽細胞の形態と構造に関する 時期的な推移変化について透過電子顕微鏡を用い て観察をおこなった。

1. 初期段階の内エナメル上皮は不規則な形態 の立方形をなし，核の存在位置も不定で，細胞小 器官の発育も悪い。

2. 象牙質の基質形成が近づくにつれて，わず かながら細胞の背丈が伸長し，形態も徐々にとと のってくる。象牙質基質形成の初期では核が細胞 のほほ中央ないしは中央よりやや基底側に位置し ている。しかし細胞の伸長にともなって核は細胞 の基底側に位置するようになる。

3. 象牙質基質の石灰化期に近つく頃に, Golgi area は発達を示すとともに核より機能側細胞質に 移動する。

それにともない rER と mitochondria が増加 し, mitochondria は細胞の 機能側細胞質に局在 するようになる。それ以後 mitochondria の局在 性はエナメル質基質形成の末期にいたるまで持続 される。
4. Golgi area の発達と移動にともない, Golgi area もしくはその近傍に, 大小さまざまな顆粒状 構造物 $\left(\mathrm{L}_{1}, \mathrm{~L}_{2}\right.$ 顆粒), multivesicular body や杆 状体などが多く出現するようになる。なお杆状体 は以後エナメル質基質形成期を通じて観察され る。

5. 象牙質基質の石灰化期では， $\mathrm{L}_{1}$ 顆粒や $\mathrm{L}_{2}$ 顆粒が Golgi area のみならず，機能側細胞質に 広範囲に観察されるようになるとともに, 分泌顆 粒が Golgi area その他の細胞質に出現しはじめ る。以後分泌顆粒はエナメル質基質形成が完了す るまで引き続き出現する。

6. エナメル質基質形成期においても，その初 期では細胞が徐々に伸長し，エナメル質基質があ る程度形成されたのちにはじめて細胞長が最大と なる。それにともなって, Golgi area や rER が 最も発達した状態となり Golgi area ならびにそ の他の細胞質では， $\mathrm{L}_{1}$ 顆粒が减少消失し， $\mathrm{L}_{2}$ 顆 粒のみとなる。

7. 象牙質基質に 象牙質の結晶の沈着がはじま る時期が近つくと，機能端に terminal bar が形 成されはじめる。

8. 象牙質基質形成期までは，内エナメル上皮 細胞の機能端細胞膜は比較的平滑で，象牙質基質 表面に位置する basement membrane に近接し ている。しかし細胞機能端に terminal bar が形 成され，象牙質の石灰化が基質表層に近づくにつ れ，機能端細胞膜面に細胞小突起が突出し，それ

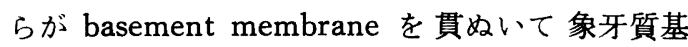
質内に侵入する。

9. さらに細胞小突起のほか不規則な 細胞膜彎 入が出現し，それらの増加にともなって基質表面 に存在する basement membrane が消失する。

10. 象牙質の 石灰化が 基質表面に 達するのと ほぼ同時に，象牙質表面にエナメル質の結晶が沈 着しはじめる。しかしエナメル質の結晶の沈着に 先だち, 細胞膜繇入部をはじめ, 機能端の細胞膜 外に amorphous material が出現しはじめる。エ ナメル質の結晶が沈着しはじめる頃になると，機 能端細胞膜における 細胞小突起や細胞膜彎入は減 少する。

11. エナメル質の 結晶の 沈着が はじまると, 
芽細胞の機能端細胞膜は 比較的平滑となるととも に，また再び管状の細胞膜彎入が観察されるょう になる。

12. 芽細胞の 機能端細胞膜に多数の細胞小突 起や細胞膜第入が生じ，さらにエナメル質の結晶 が沈着し始める頃から terminal bar は徐々に後 退しはじめ，さらにエナメル質基質形成期にいた り，エナメル質の形成がある程度進行した時期に， terminal bar は機能端からややはなれた位置に固 定されるようになる。それにともなって terminal bar ならびに terminal web が発達を示すよう になる。

13. terminal bar の後退により, 機能端細胞 質が terminal bar の位置からわずかに突出する 状態となるが，哺乳類におけるようなトームスの 突起の形成にはいたらない。しかし，機能端細胞 質における構造は基本的に哺乳類や魚類のそれと 差はみられない。

14. エナメル質基質形成期における芽細胞の 機能端細胞膜は比較的平滑で，管状の細胞膜韵入 が一層増加するとともに, これらの細胞膜彎入部, その他の細胞膜外に amorphous material が密に 観察され，順次エナメル質の基質形成が進行して いく。

15. エナメル質基質形成末期になると，Golgi area ならびに, それ以外の細胞質に $\mathrm{L}_{2}$ 顆粒のほ か, Lm 顆粒が出現し順次増加する。また, terminal bar が再び機能端に移動し, mitochondria の局在性が消失するとともに，その matrix も明 調となり $r E R$ の発達も低下する。

稿を終るにのぞみ, 終始御指導御校閲いただきました 本学第二口腔解剖学教室, 一条 尚教授に深く感謝の意 を表します。また本研究を遂行するにあたって終始丁寧 な御助言をいただきました本学第一口腔解剖学教室, 桐 野忠大教授に梁く感謝の意を表しますとともに, 口腔解 剖学教室員諸氏に心からお礼申し上げます。なお本研究 のために貴重な資料を提供していただきました熱川バナ ナ・ワニ園の木村亘園長をはじめ, ワ二の飼育・研究に 橴わっておられる倸の皆様に心からお礼申し上げます。

\section{文献}

1) Fontana. : On Poison, Part 1. Treatise on the Venom of the Viper, \& c., translated by Skinner, 8vol. 2d Ed. 1795, p. 10 (The original Treatise was published in Italian, in 1765).

2) OWEN, R.: Odontography; or a Treatise on the comparative anatomy of the teeth; Their physiological relations, Mode of development, and Microscopic structure in the Vertebrate animals. Hippolyte Bailliere Pub., London. 1840-45.

3) Tomes, C. S. : On the development and succession of the Poison-fangs of snakes. Phil. Trans. R. Soc. Lond., 166 : 377-385. 1876.

4) Tomes, C. S.: A manual of Eental Anatomy, human and comparative. London J. \& A. Churchill, p. 278, 1923,

5) WoERdeman, M. W. : Beiträge zur Entwicklungsgeschichte von Zähne und Gebiss der Reptilien, Beträg IV : Über die Anlage und Entwicklung der Zähne. Archs. mikrosk. Anat., 95 : 265-397, 1921.

6) BoLK, L.: Odontological Essays. IV. On the relation between reptilian and mammalian. J. Anat., 56 : 107, 1922.

7) Bolk, L. : Odontological Essays. V. On the relation between reptilian and mammalian. J. Anat., 57 : 55, 1923.

8) LEYdIG, F.: Die Zähne einheimischer Schlangen nach Bau und Entwicklung. Archs. mikrosk. Anat., 9 : 1-35, 1873.

9) Kathariner, L. : Über Bildung und Ersatz der Giftzähne bei Giftschlangen. Zoolog. Jahrb. Abth, für Aatomie, 10 : 52, 1897.

10）恵 平治 : 八ブに関する研究. 口腔科学会雑誌, 5 : 151-154, 1933.

11) Röse, C. : Über die Zahnentwicklung der Kreuzotter (Vipera berus L.), Anat. Anz., 9 : 439-451, 1894.

12) VOERCKEL. Untersuchung der Giftzähne von Pelias, Leipzig, 1895.

13）高橋敬文 : 台湾産毒蛇毒器の研究. 解剖学雑誌, 18 : 380-392, 1941.

14) Poole, D. F. G.: The formation and properties of the organic matrix of reptilian tooth Enamel. Quart. J. micr. Sci., 98: 349-367, 1957.

15) Poole, D. F. G. : Phylogeny of tooth tissues. Enameloid and enamel in recent vertebrates, with a note on the history of cementum. Structural and Chemical Organization of Teeth (edited by A. E. W. Miles), 
Vol. I, 111-149, Academic Press, New York, 1967.

16) KvUM, T.: The teeth of Alligator mississippiensis Daud, III. Development of enamel. J. Dent. Res., 37 : 540-546, 1958 b.

17) Bellairs, A.: The Life of Reptiles, Vol. 1, 170-180, The Weidenfeld and Nicolson, Natural History Weidenfeld and Nicolson, 1969.

18) PEYER, B. : Comparative Odontology (translated and edited by R. Zangerl), The Univ. of Chicago Pr., Chicago and London, 1968.

19）馬場彰一：日本産マムシの Giftapparat の発生 学的研究. 解剖学雑誌, $10: 274-328,1937$.

20) LEvY, H. : Beiträge zur Kenntnis des Baues und der Entwicklung der Zähne bei den Reptilien. Jena. Z. Naturwiss, 32 : 313, 1898.

21) Martin, M.: Recherches sur le developpment de la Vipera aspis. C. R. de I'Assoc. Anatomist 1 sess. Paris 1809, Bibliogr. Anat. Suppl. 1899.

22) 頼 海元： マムシの毒牙の組織発生学的研究. 口病誌, 39 : 26-63, 1972.

23) Mummery, J. H. : The Microscopic and General Anatomy of the Teeth, Human and Comparative. Oxford Medical Publication, Oxford, 1924.

24) EDMUND, A. G.: Tooth replacement phenomena in the lower vertebrates. $R$. Ont. Mus., Life Sci. Div., Contr., 52 : 1-190, 1960.

25) Edmund, A. G.: Biology of the Reptilia (edited by Gans, C.), London and New York, Academic Press, p. 117, 1969.

26) Poole, D. F. G. : Notes on the replacement in the Nile Crocodile Crocodilus Niloticus. Proc. Zool. Soc. Lond., 136 : 131-140, 1961.

27) Tomes, C. S.: Upon the development of the enamel in certain osseous fish. Phil. Trans. R. Soc. Lond., 193 (B) : 35-46, 1900.

28) KVAM, T.: Comparative study of the ontogenetic and phylogenetic development of dental enamel. Den Norske Trannlaegeofor. Tid., 56 : Supplement, 1946.

29) KVAM, T.: The development of mesodermal enamel on piscine teeth. $K$. norske vidensk. Selsk. Forh., 23 : 1-115, 1950.

30) KvaM, T.: The phylogenetic transition from mesodermal to ectodermal enamel. Det. Korg. Norske Videnskal. Selsk. Forhandl., 26 : 83-84, 1953.

31) KvaM, T.: The tooth of Alligator mississippiensis Daud. II. Development of dentin. J. Dent. Res., 37 : 532-539, 1958 a.

32) KVAM, T.: The teeth of Alligator mississippiensis Daud. V. Morphology of the ena- mel. Acta Odon. Scand., $17: 45-59,1958$

33) KVAM, T.: Forming of the tooth germ in Triton cristatus Laur. Nytti Mag. Zool., 9 : 28, 1960.

34) Kvam, T.: The development of the tooth tip in Triton cristatus Laur. Acta Odont. Scand., $18: 503,1960$.

35）脇田 稔：ニザダイのエナメル質形成時におけ るエナメル芽細胞の微細構造に関する研究. 歯 基礎誌, 16 : 129-185, 1974.

36）小野 毅：イシダイのエナメル質形成時におけ るエナメル芽細胞の微細構造に関する電子顕微 鏡的観察. 歯基礎誌, $16: 407-464,1974$.

37) WAGNER, G.: Chimaerische Zahnanlagen aus Triton-Schmelzorgan und BombinatorPapille. J. Embryol. Exp. Morph., 3 : 160, 1955.

38) Gillette, R.: The dynamics of continuous succession of teeth in the frog (Rana pipiens). Amer. J. Anat., 96 : 1, 1955.

39) KERR, T.: Development and structure of some actinopterygian and urodele teeth. Proc. Zool. Soc. Lond., 133 : 401, 1960.

40) LAwson, R.: The development and replacement of teeth in Hypogeophis rostratus. J. Zool., 147 : 352, 1965.

41) Meredith SMith, M. and Miles, A. E. W. : An autoradiographic investigation with the light microscope of proline- $\mathrm{H}^{3}$ incorporation during tooth development in the crested newt (Triturus cristatus). Archs oral Biol., $14: 479,1969$.

42) 川崎堅三 : イモリの歯の組織発生学的研究. 歯 基礎誌, 13 : 95-137，1971.

43）桐野忠大，一条 尚，星野悦郎，小野 毅，脇 田 稔, 小沢幸重, 鈴木駿介, 山下靖雄, 後藤 仁敏：魚類エナメル質の組織発生学的研究. 解 剖誌, $47: 77,1972$.

44）桐野忠大, 一条 尚, 脇田 稔, 小野 毅, 星 野悦郎, 鈴木駿介, 小沢幸重, 山下靖雄, 後藤 仁敏：魚類のエナメル来細胞にみられる顆粒に ついて. 口病誌, $39: 241,1972$.

45）一条 尚, 小沢幸重, 後藤仁敏, 山下靖雄: 魚 類の歯の構造とその形成, 3. 魚類の歯の構造と 発生. 菌界展望, $43: 1123-1126,1974$.

46）一条 尚, 後藤仁敏, 山下靖雄, 小沢幸重 : ド チザメのエナメル質形成に関する電子顕微鏡的 観察. 歯基礎誌, $16: 506,1974$.

47）一条 尚, 山下靖雄, 小沢幸重, 後藤仁敏 : ワ 二のエナメル質形成に関する電子顕微鏡的観察. 歯基礎誌, $16: 506,1974$.

48）一条 尚, 山下靖雄, 後藤仁敏, 小沢幸重 : 1 ヌのエナメル質形成に関する電子顕微鏡的研究. 歯基脴誌, $16: 507,1974$.

49）桐野忠大, 一条 尚, 小沢幸重, 後藤仁敏, 小 野 毅, 脇田 稔, 山下靖雄: ワニ（メガネカ 
イマン) の歯に関する発生学的研究. 解剖誌, $49: 61,1974$.

50）桐野忠大, 一条 尚, 脇田 稔, 小野 毅, 小 沢幸重, 山下靖雄, 後藤仁敏 : ドチザメの歯に 関する発生学的研究. 解剖誌, $49: 61,1974$.

51）桐野忠大, 一条 尚, 小野 毅, 脇田 稔, 山 下靖雄, 後藤仁敏, 小沢幸重 : イヌのエナメル 質形成に関する電子顕微鏡的観察. 解剖誌, 49 : 62, 1974.

52）山下靖雄 : ワニ（Caiman Crocodilus）の歯に 関する組織発生学的研究. 口病誌, $42: 328$, 1975.

53) 一条 尚, 山下靖雄: ワニ（メガネカイマン Caiman Crocodilus) の歯について. 熱帯動植 物友の会(特集号)，8，1975.

54) William, A. M. and CarolyN, J. P. R. : Tooth Replacemaent Patterns in young Caiman sclerops. J. Morph., 130 : 501-510, 1970.

55）桐野忠大, 一条 尚, 後藤仁敏, 小野 毅, 小 沢幸重, 脇田 稔, 山下靖雄, 鈴木駿介, 星野 悦郎：走査型電子顕微鏡によるエナメル質の比 較解剖学的研究. 口病誌, $39: 535,1972$.

56）桐野忠大, 一条 尚, 脇田 稔, 山下靖雄, 鈴 木駿介, 後藤仁敏, 小野 毅, 小沢幸重 : ヒ卜 のエナメル質形成に関する電子顕微鏡的観察. 口病誌, $39: 824,1972$.

57）桐野忠大, 一条 尚, 小野 毅, 小沢幸重, 山 下靖雄，鈴木臤介，後藤仁敏：エナメル翼の成 長線に関する走査型電子顕微鏡的研究. 口病誌, 39 : 538, 1972.

58）桐野忠大, 一条 尚, 後藤仁敏, 山下靖雄, 小 野 毅, 脇田 稔, 鈴木駿介, 小沢幸重 : ヒト のエナメル質に関する走査型電子顕微鏡的観察 （その 2 ) 成長線について. 歯基礎誌，14:440$441,1972$.

59）桐野忠大, 一条 尚, 後藤仁敏, 小野 毅, 小 沢幸重, 山下靖雄, 脇田 稔, 鈴木駿介 : ヒト エナメル質の構造に 関する 走查型電子顕微鏡的 研究. 1.エナメル小柱の形態ならびに小柱䩗と 小柱間質について. 口病誌, $39: 247-296,1972$.

60）桐野忠大, 一条 尚, 小沢幸重, 脇田 稔, 山 下靖雄, 鈴木駿介, 後藤仁敏, 小野 毅 : エナ メル質の低石灰化帯ならびに過石灭化帯に関す る走查型電子顕微鏡的研究. 口病誌, 39 : 537538, 1972.

61）桐野忠大, 一条 尚, 小沢幸重, 脇田 稔, 山 下靖雄, 鈴木駿介, 後藤仁敏, 小野 毅 : 七ト エナメル質の形成にともなう crystal の変化に ついて. 解剖誌, $48: 37,1973$.

62）桐野忠大，一条 尚，小野 毅，小沢幸重，脇 田 稔, 山下靖雄, 鈴木駿介, 後藤仁敏 : ヒト エナメル質の構造に関する発生学的研究. 解剖 誌, $48: 36-37,1973$.

63) HEROLD, R. C. B. : Ultrastructure of odontogenesis in the Pike (Esox lucius). Role of dental epithelium and formation of ena- meloid layer. Ultrastruct. Res., 48 : 435-454, 1974.

64) ZAKI, A. E., YAEger, A. and GILletTE, R.: Fine structure of the epithelial dental organ in the frog during early odontogenesis. Anat. Rec., 168 : 79-92, 1970.

65) Meredith Smith, M. and Miles, A. E. W.: The ultrastructure of odontogenesis in larval and adult urodeles; differentiation of the dental epithelial cells. Z. Zellforsch., 121 : 470-498, 1971.

66) Pannese, E.: Observation on the ultrastructure of the enamel organ. III. Internal and external enamel epithelia. $J$. Ultrastruct. Res., 6 : 186-204, 1962.

67) DECKER, J. D. : A light and electron microscope study of the rat molar enamel organ. Archs oral Biol., 8 : 301-310, 1963.

68) REITH, E. J.: The early stage of amelogenesis as observed in molar teeth of young rats. J. Ultrastruct. Res., 17 : 503-526, 1967.

69) Frank, R. M. and NAlbandiAN, J. : Ultrastructure of Amelogenesis. Structural and Chemical Organization of Teeth (edited by A. E. W. Miles), Vol. I, 399-466, Academic Press, New York, 1967.

70）一条 尚：エナメル芽細胞の発育による形態と 構造の時期的な推移変化ならびに基質形成につ いて.「硬組織研究一歯の形成を中心として「(荒 谷真平ほ加編)，306-342, 医歯薬出版，東京， 1969.

71) KallenBACH, E. : Electron microscopy of the differentiating rat incisor ameloblast. J. Ultrastruct. Res., 35 : 508-531, 1971.

72) Katchburian, E. and Holt, S. J.: Studies on the development of ameloblasts. I. Fine structure. J. Cell Sci., $11: 415-447$, 1972.

73）山 清: ヒトほうろら芽細胞の超微細構造. 歯 科学報, 71 : 1531-1574, 1971.

74) Garant, P. R. and Nalbandian, J. : Observation on the ultrastructure of ameloblasts with special reference to the Golgi complex and related components. J. Ultrastruct. Res., 23 : 427-443, 1968.

75) FEARNHEAD, R. W. : Mineralization of rat enamel. Nature, Lond., 189 : 509-510, 1960.

76) NYLEN, M. U. and ScotT, D. B. : Electron microscopic studies of odontogenesis. J. Indiana St. dent. Assoc., 39 : 406-421, 1960.

77) REITH, E. J.: The ultrastructure of ameloblasts from the growing end of rat incisors. Archs. oral Biol., 2 : 253-262, 1960.

78) REITH, E. J.: The ultrastructure of ameloblasts during matrix formation and the maturation of enamel. J. biophys. biochem. 
Cytol., 9 : 825-839, 1961.

79) RönNHolm, E.: An electron microscopic study of the amelogenesis in human teeth. I. The fine structure of the ameloblasts. $J$. Ultrastruct. Res., 6 : 229-248, 1962.

80) QUigley, M. B. : Electron microscopy of developing enamel matrix in the syrian hamster. J. dent. Res., 38 : 180-187, 1959.

81）倉橋和啓, MOE, H. : ラット切歯珐瑯質の基 質形成後期および成熟期における造珐瑯細胞の 電子顕微鏡所見, 「硬組織研究一歯の形成を中心 として」(荒谷真平ほか編)，254-285，医歯薬 出版, 東京, 1969 .

82) KallenbaCH, E.: Fine structure of rat incisor ameloblasts during enamel maturation. J. Ultrastruct. Res., 22 : 90-119, 1968.

83) Jasswoin, G.: On the structure and development of the enamel in mammals. Quart. J. Mic. Sci., 69 : 97-118, 1925.

84) Bearns, H. W. and Kings, R. L.: The Golgi apparatus in the developing tooth, with special reference to polarity. Anat. Rec., 57 : 29-39, 1933.

85）星 和夫：人の歯のエナメル芽細胞と象牙芽細 胞のゴルジ質について. 解剖誌, $32:$ 434-453, 1957.

86) WARSHAWSKY, H. : The fine structure of secretory ameloblasts in rat incisors. Anat. Rec., 161 : 211-230, 1968.

87）田熊庄三郎, 林 文隆, 柳沢孝彰 : ラット切歯 骨様象牙質の形成に関する電子顕微鏡的研究. 歯基礎誌, $17: 445-515,1975$.

88) FEARNHEAD, R. W.: Electron microscopy of forming enamel. Archs. oral Biol., 4 : 24-28, 1961.

89) Elwood, W. K. and Bernstein, M. H. : The ultrastructure of the enamel organ related to enamel formation. Am. J. Anat., 122 : 73-94, 1968.

90）田熊庄三郎：ヒトおよびラット珐瑯質の石灰化
に関する電子顕微鏡的研究.「硬組織研究一歯の 形成を中心として一」(荒谷真平ほか編)，228249 , 医歯薬出版, 東京, 1969.

91）塩田研次：エナメル質結晶（ラット）の形成と 成長過程についての電子顕微鏡的観察.「硬組織 研究一歯の形成を中心として一」(荒谷真平ほか 編)，286-305，医歯薬出版，東京， 1969.

92) REITH, E. J.: The stages of amelogenesis as observed in molar teeth of young rats. $J$. Ultrastruct. Res., 30 : 111-151, 1970.

93) Watson, M. L.: The extracellular nature of enamel in the rat. J. biophys. biochem. Cytol., 7 : 489-492, 1960.

94) 小沢英浩 : 歯牙硬組織の微細構造. 細胞, $4: 2-$ 24, 1972 .

95) TAKUMA, S.: Ultrastructure of dentinogenesis. Structural and Chemical Organization of Teeth (edited by Miles, A. E. W.), Chapt. $8: 325-368$, New York, Academic Press, 1967.

96) Butcher, E. O.: Enamel rod matrix formation in the rat's incisor. $J$. Am. dent. Ass., 53 : 707-712, 1956.

97) Weill, R. et MARIE-Therese TASSIN : Étude de l'adamantogenèse chez certains reptiles. Archives d'Anatomie microscopique, 59 : 427-434, 1970.

98) EAstoe, J. E. : The amino acid composition of proteins from the oral tissues. II. The matrix protein from developing human deciduous teeth. Arch. oral Biol., 8:633652, 1963.

99) FEARnhEAd, R. W.: Recent observation on the structure of developing enamel. Arch. oral Biol., 8(Spec. Suppl. ORCA meeting, Paris 1962) : 257-264, 1963.

100) KallenbaCH, E. : The structure of Tomes' process of rat incisor ameloblasts and its relationship to the elaboration of enamel. Tissue \& Cell, 5 : 501-524, 1973. 


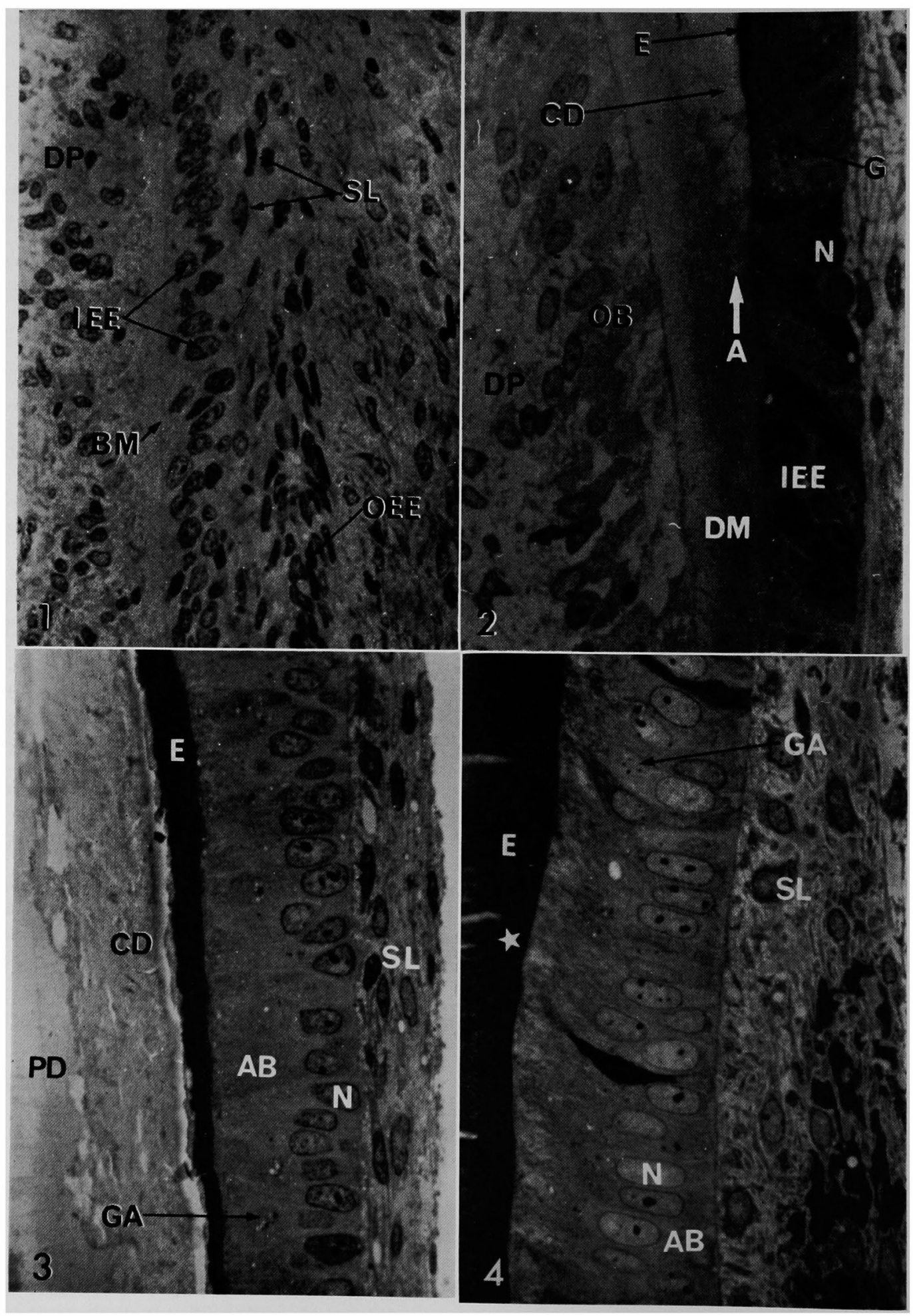




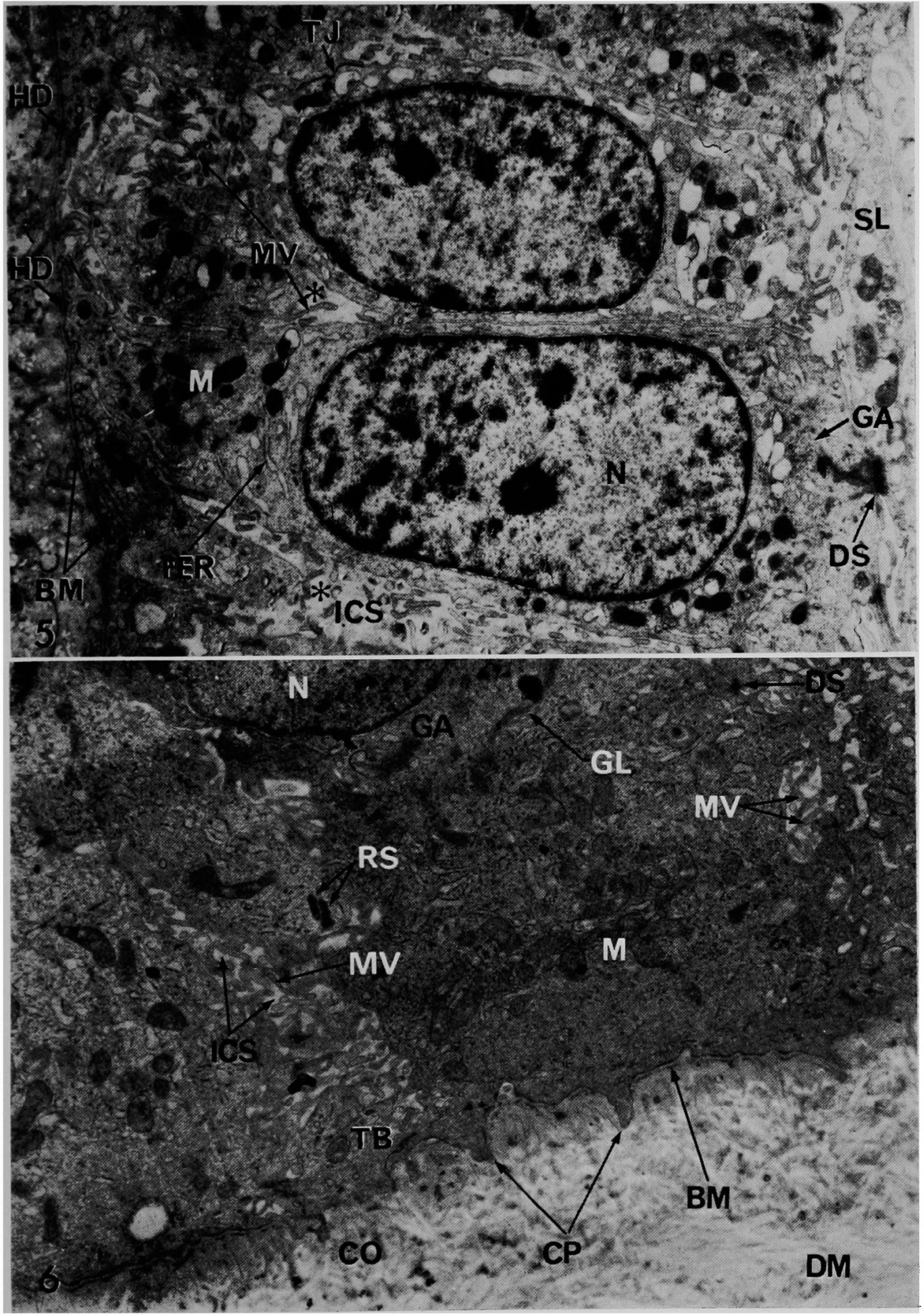




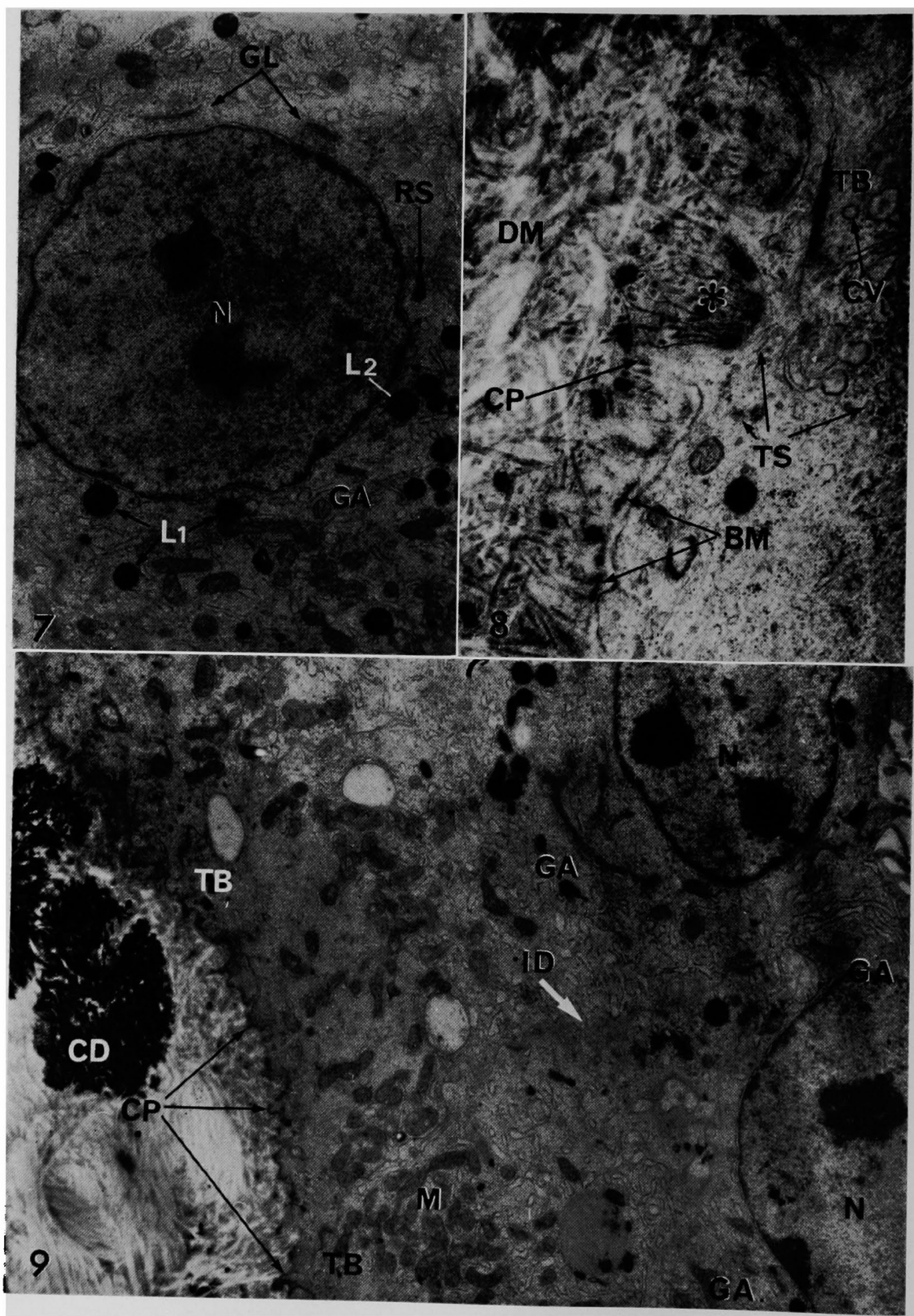




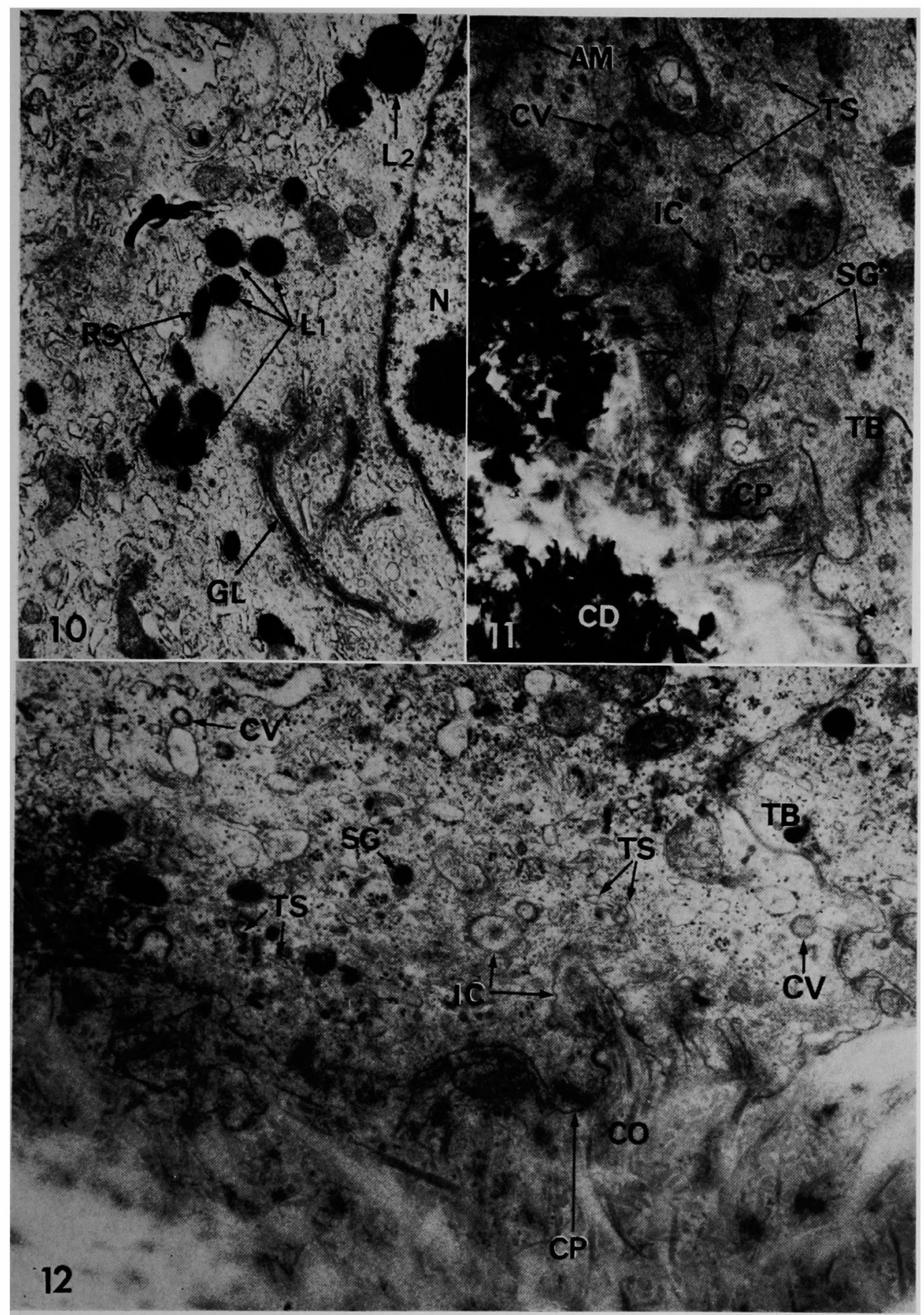




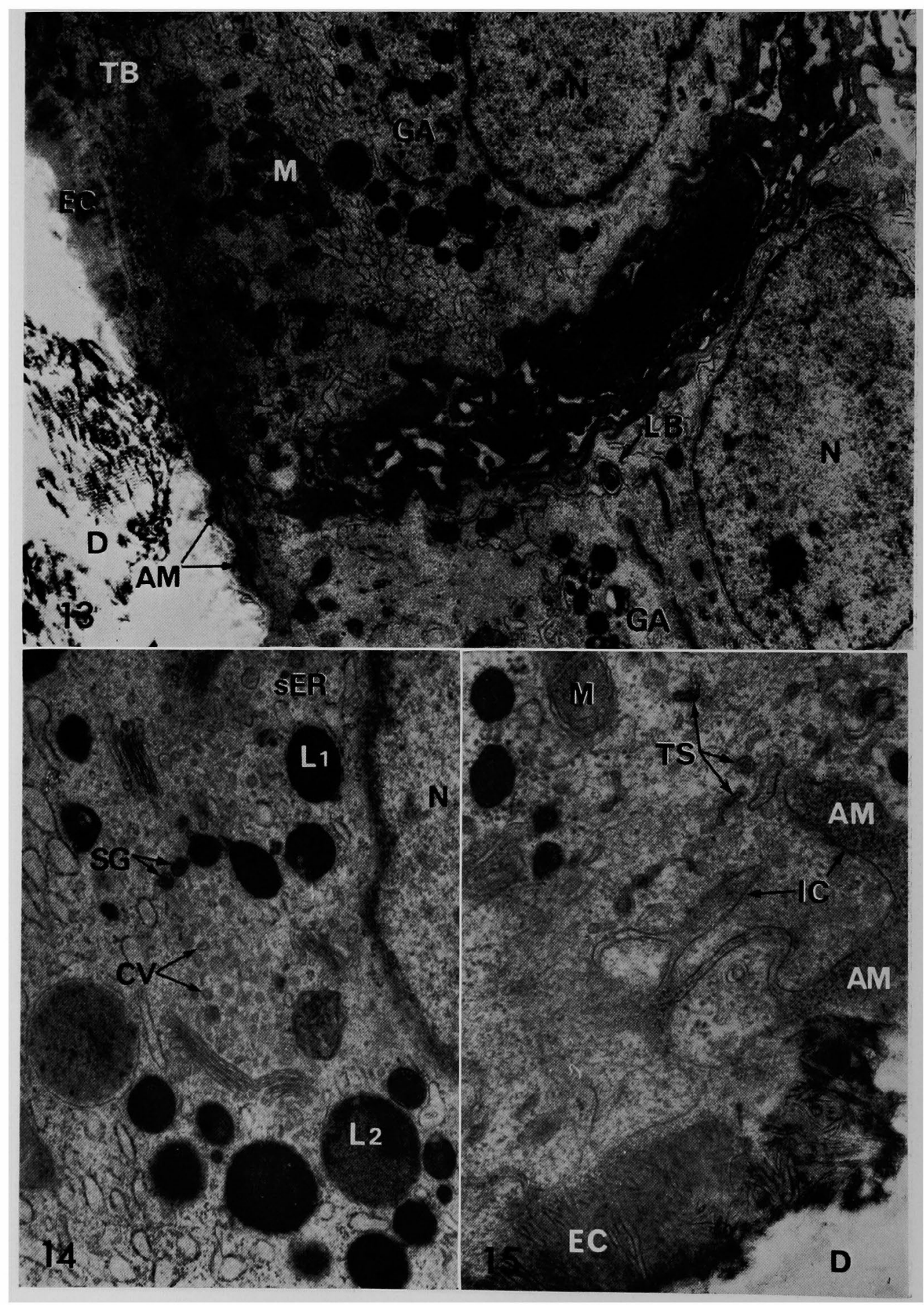




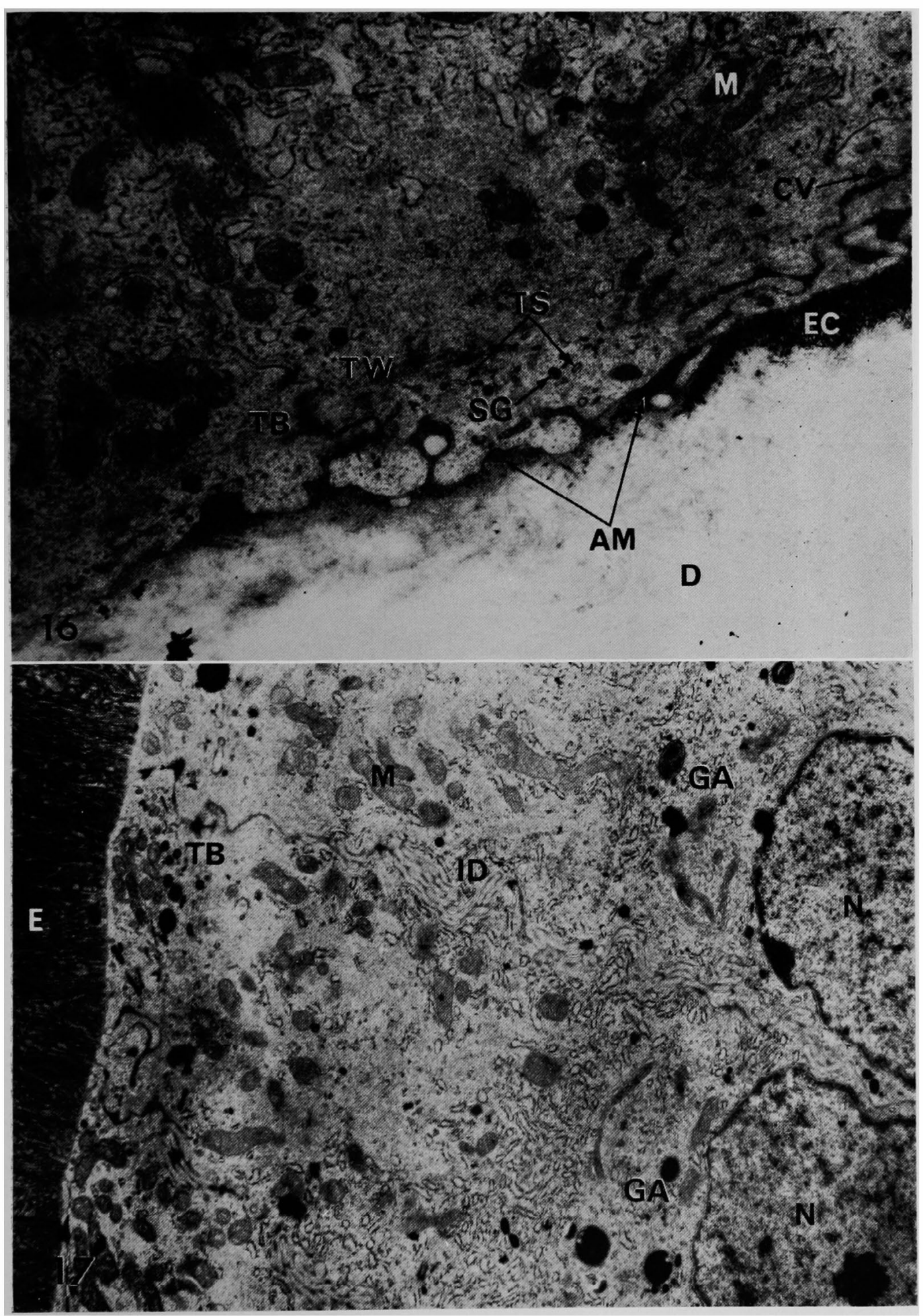




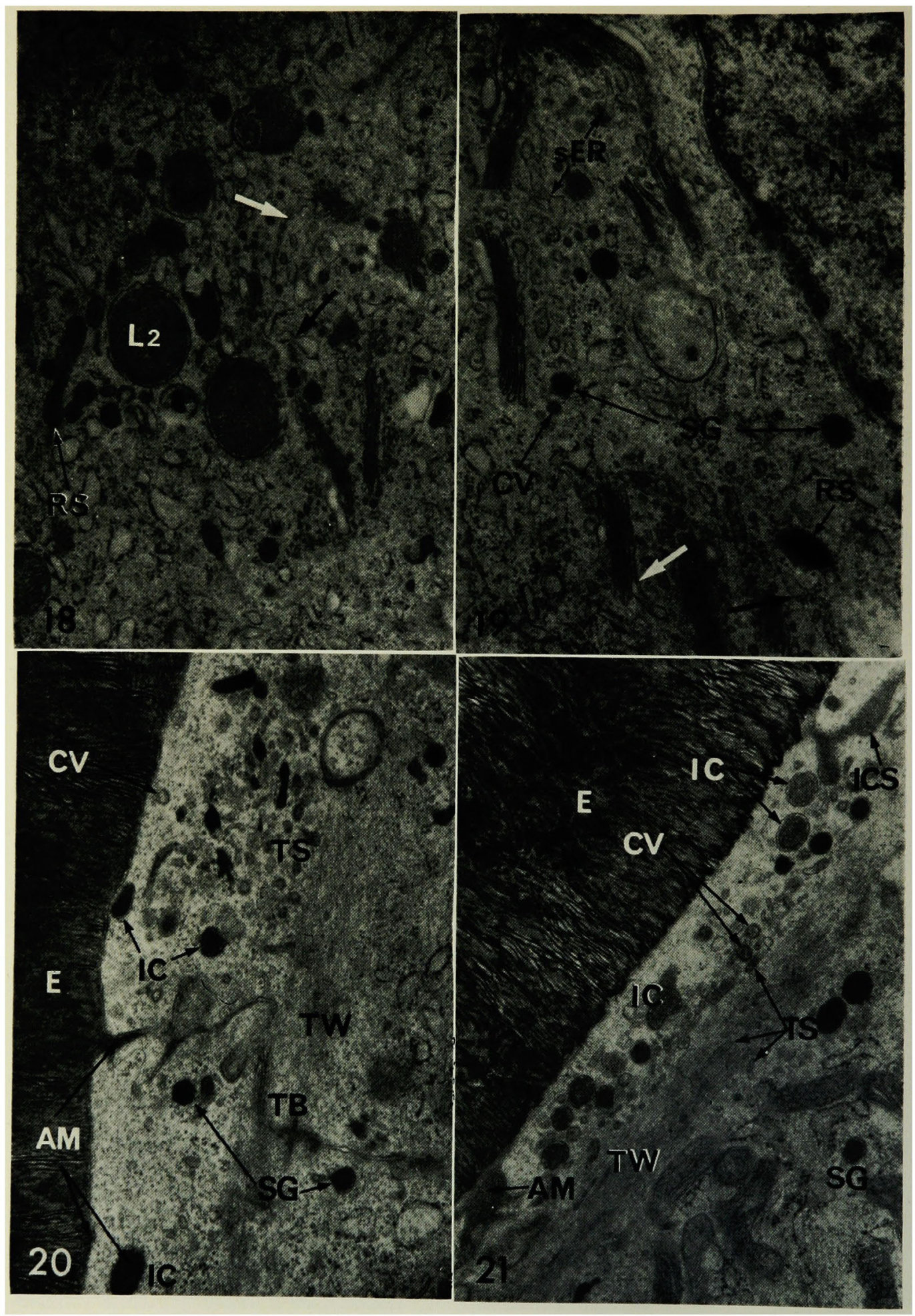




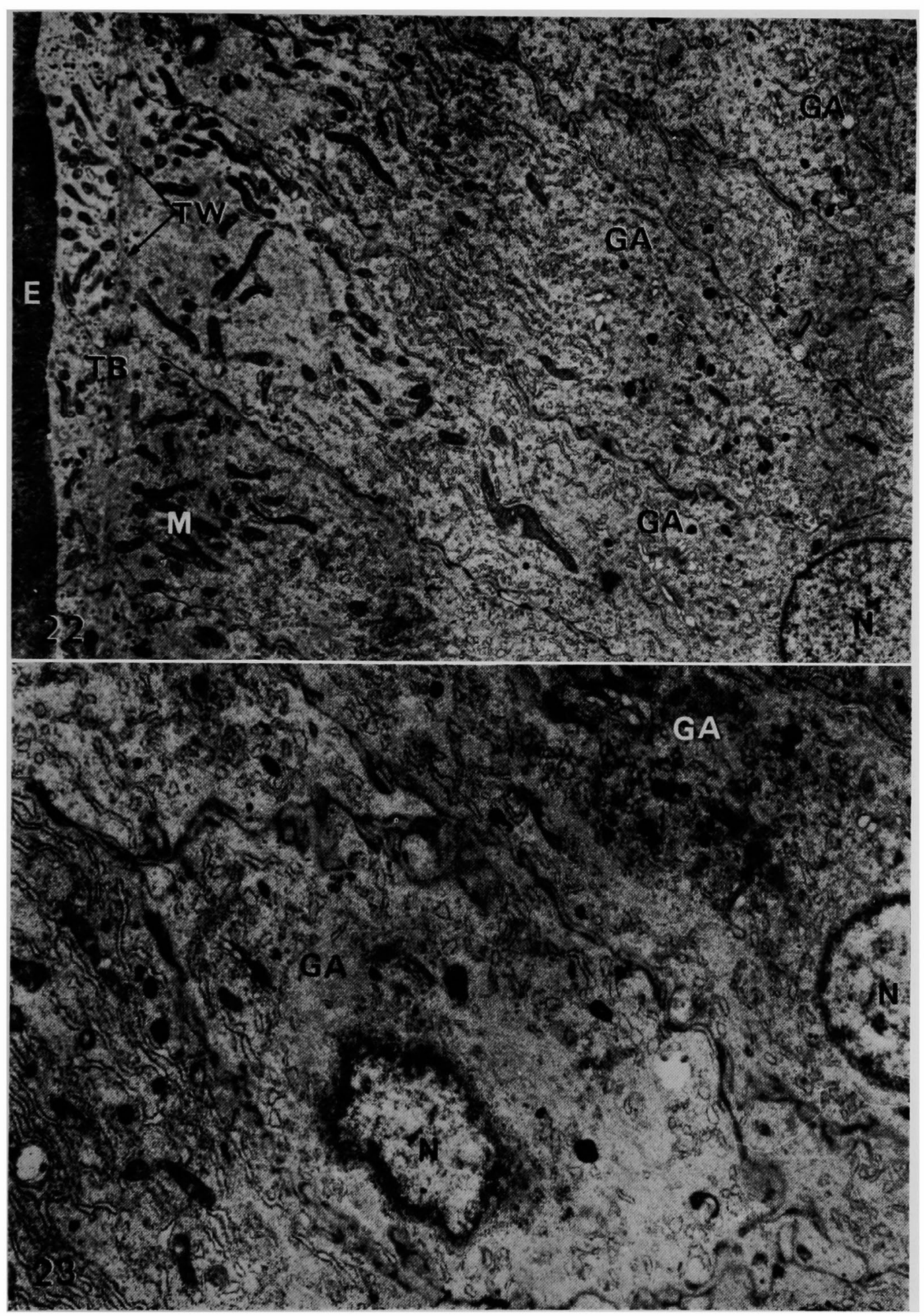




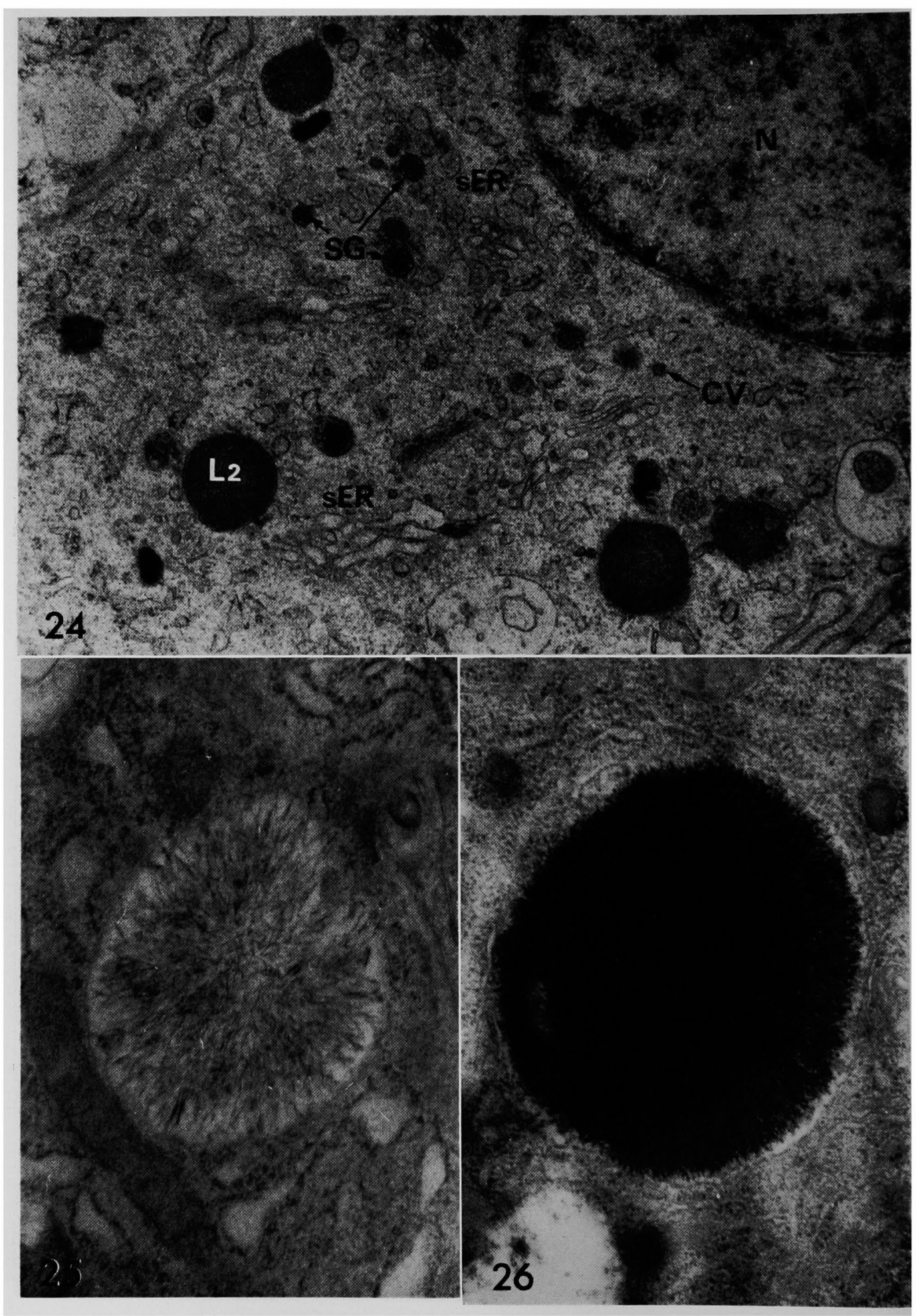




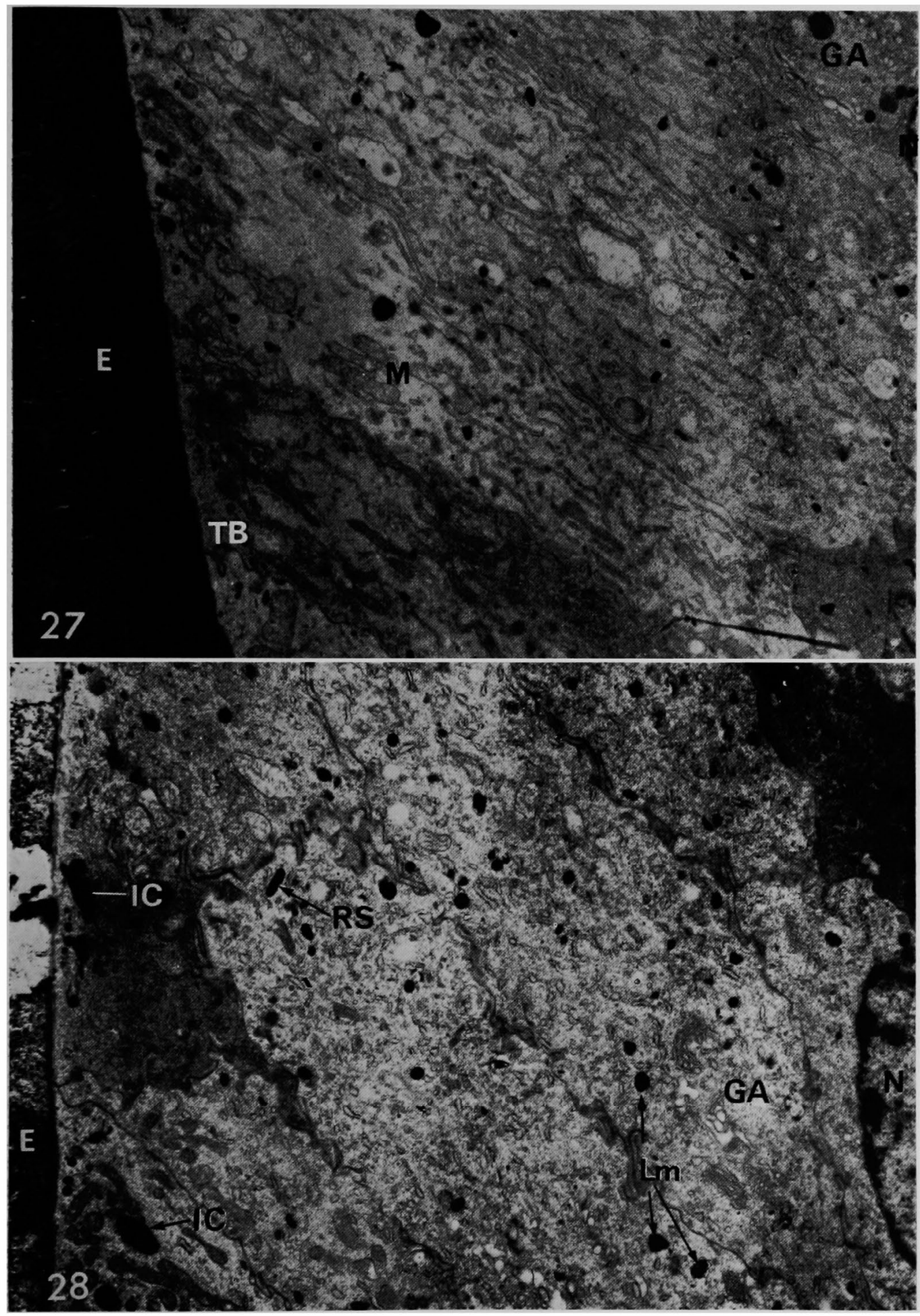




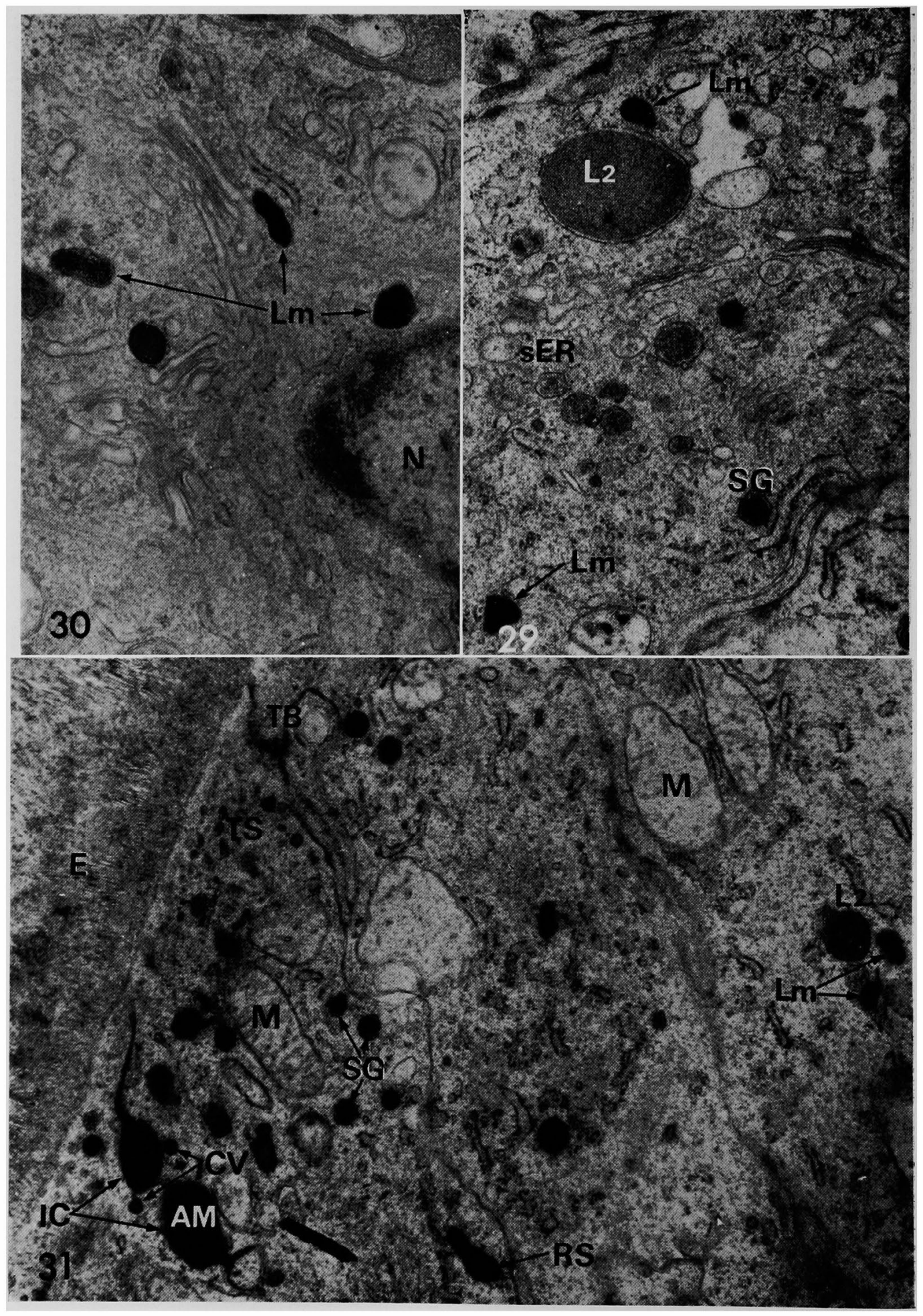


付図記号説 明

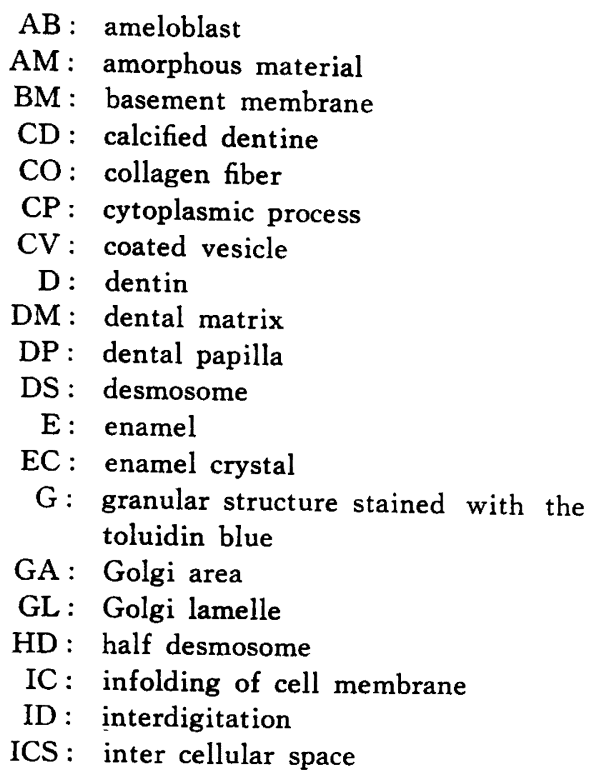

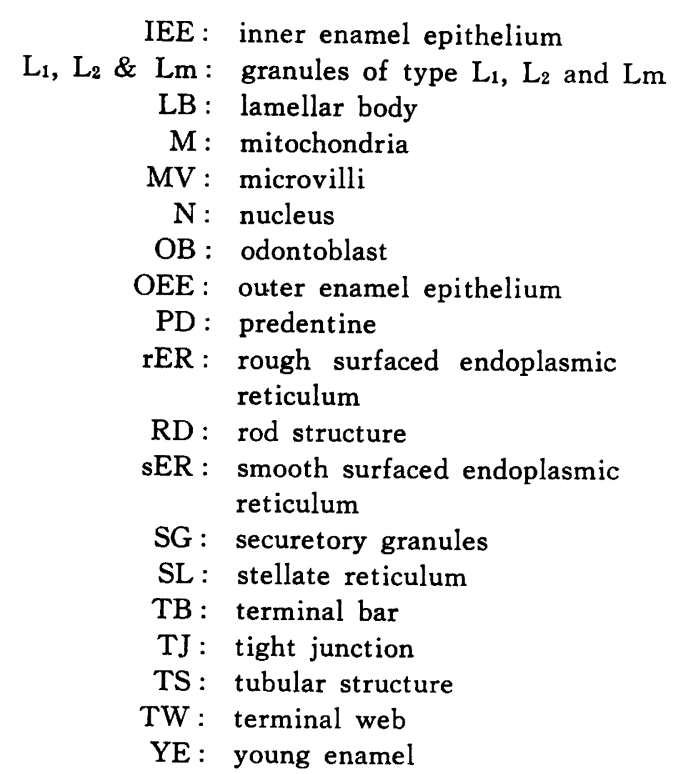

$\begin{aligned} & \mathrm{Lm}: \text { granules of type } \mathrm{L}_{1}, \mathrm{~L}_{2} \text { and } \mathrm{Lm} \\ & \mathrm{LB}: \text { lamellar body } \\ & \mathrm{M}: \text { mitochondria } \\ & \mathrm{MV}: \text { microvilli } \\ & \mathrm{N}: \text { nucleus } \\ & \mathrm{OB}: \text { odontoblast } \\ & \mathrm{OEE}: \text { outer enamel epithelium } \\ & \mathrm{PD}: \text { predentine } \\ & \mathrm{rER}: \text { rough surfaced endoplasmic } \\ & \text { reticulum } \\ & \mathrm{RD}: \text { rod structure } \\ & \mathrm{sER}: \text { smooth surfaced endoplasmic } \\ & \text { reticulum } \\ & \mathrm{SG}: \text { securetory granules } \\ & \mathrm{SL}: \text { stellate reticulum } \\ & \mathrm{TB}: \text { terminal bar } \\ & \mathrm{TJ}: \text { tight junction } \\ & \mathrm{TS}: \text { tubular structure } \\ & \mathrm{TW}: \text { terminal web } \\ & \mathrm{YE}: \text { young enamel }\end{aligned}$

\section{付 図説明}

図 1〜 4 は toluidin blue 染色光顕像（倍率は撮影倍率）

図 1 象牙質基質形成前の内エナメル上皮 歯胚の上皮性要素は外エナメル上皮 (OEE)，エナメル髄（SL)，および内エメメル上皮 (IEE) から なる。内エナメル上皮は basement membrane (BM) を介して非常に幼若な象牙芽細胞に相対して いる。初期状態の内エナメル上皮（写真下方）は形態が非常に不規則であるが，時期が進むにつれて 短円柱形となり，順次形態がととのってくる。それにともなって核は大きくなるが，その存在位置は 不定である。 ×200

図 2 象牙質基質形成期からエナメル質基質形成初期の内エナメル上皮 内エナメル上皮細胞 (IEE) は発育が進むにつれて徐々に背丈を伸長する。また図の下方の細胞では, 核 $(\mathrm{N})$ が細胞のほぼ中央に位置しているが, 細胞の伸長にともない, 核が順次基底側に移動し, 象牙 翼の石灰化が始まる以前に核が基底側に位置する。また核が基底側に移動すると，直ちに核より機能 側細胞質にトルイジンブルーで濃染する顆粒状構造物 (G) が出現し, 順次その数が増加している。 象牙質の基質形成がある程度進行すると，形成された象牙質基質の表層約 1/6 1/8 領域（A点）から 石灰化が始まり，さらに象牙質基質表面と歯乳頭側の二方向に向って進行している。やがて象牙質の 石灰化が象牙質基質の表面にまで達するのと，ほぼ同時にエナメル質の基質が形成されはじめている。 $\times 400$

図 3 エナメル質基質形成の初期

エナメル質基質の形成が進み石灰化が進行するにともない，深層ではすでにかなり硬度が増している。 エナメル芽細胞 (AB) は基質形成が進行するにしたがって細胞長がわずかながら伸長している。核 （N）の機能側に位置している Golgi area（GA）では，顆粒状構造物などが多く観察され，エメナ ル質基璂形成が進むにつれ，機能側の細胞質領域に明調な部分が出現している。 $\times 400$

図 4 図 3 の標本よりエナメル啠基澌形成がさらに進んだ時期の芽細胞 エナメル翼基犋形成面からわずかの幅の部分ではエナメル質が幼若であるが(々の部分)，それより深 層では石灰化の進行によってかなり硬度をが増している。エナメル芽細胞 $(\mathrm{AB})$ の細胞長は最大とな っている。Golgi area (GA) はかなり拡大され, 核 (N) より機能側のほぼ中央付近にまで達し, 顆粒状構造物などが観察され，機能側の細胞質における明調な部分がより明確になっている。しかし トームスの突起は観察されない。 $\times 400$

図 5 〜 31は電顕像（倍率は写真倍率）

図 5 象牙質基質形成がわずかにはじまった時期の内エナメル上皮 
細胞長がやや伸長し，形態もととのっている。核（N）は棈円形ないし卵円形をなし，相対的に大き 人, 細胞のほぼ中央ないしわずかに基底側に位置している。細胞偶角部（*)には細胞間隙 (ICS) が みられ, この領域に microvilli (MV) が観察される。機能側細胞膜は平滑な状態で, basement membrane (BM) に接し, Golgi area (GA) は核（N) より 基底側細胞質に位置するが，発達が 悪く小規模である。また, mitochondria（M）や rER も比較的数が少ない。 $\times 9000$

図 6 象牙質基質形成期における石灰化直前の内エナメル上皮

細胞離開部（ICS）の範囲がやや拡大され， microvilli (MV) が密になっている。細胞の伸長にと もない, rER の数が増し mitochondria (M) は核より機能側の細胞質の中央約 $1 / 3 \sim 2 / 4$ の領域に集 積しはじめている。Golgi area (GA) は核の機能側に近接して観察され，顆粒状構造物もみとめら れ, Golgi lamelle の長さも増している。また機能端細胞膜には, 細胞小突起 (CP) が形成されは じめ,それらが basement membrane（BM）の一部を貫いて象牙質基質（DM）に向かって突出し ている。 $\times 15000$

図 7 図 6 と同時期の細胞における核領域細胞質

Golgi area (GA) が核（N）に近接し，核の周囲をとりかこむように位置している。Golgi area お よびその近傍に各種 vesicle や lysosome 様の顆粒状構造物 $\left(\mathrm{L}_{1}, \mathrm{~L}_{2}\right)$, 杆状体 $(\mathrm{RS})$ などが多く観 察される。×7000

図 8 図 6 と同時期の細胞における細胞機能端の一部抗大

細胞小突起 (CP) が basement membrane (BM) を貫いて象牙質基質 (DM) 内にわずかに侵入し ている。小突起が存在しない領域では, basement membrane (BM) がやや不明瞭となり, half desmosome 様の構造が観察される。機能端に terminal bar (TB) が出現し, 機能端細胞質には rER などの organella がほとんどみられず，わずかの free の ribosome のほか 非常に微細な線維状構 造物が多数認められ，微細な tube 状構造 (TS) も出現している。象牙質基質表層には細い collagen 線維が, 残存する basement membrane に対してほぼ直角方向に配列している(）の部分)。 $\times 22000$

図 9 象牙質石灰化期の内エナメル上皮

細胞がやや伸長するとともに細胞間隙が減少し，隣接細胞相互間には複雑な interdigitation (ID) が観察される。Golgi area（GA）は主として核の機能側に位置するが，核の基底側および側面にも みられる。mitochondria $(M)$ と rER は数を増し， mitochondria は局在性を示している。また機 能端の細胞小笑起 $(\mathrm{CP})$ が多数出現し, basement membrane は消失している。 $\times 8000$

図 10 図 9 における Golgi area の桩大

Golgi lamelle (GL) は長くなり, Golgi area には sER が増加するとともに, Golgi vesicle, coated vesicle, 杆状体 (RS) や多数の顆粒状構造物 $\left(\mathrm{L}_{1}, \mathrm{~L}_{2}\right)$ がみとめられる。 $\times 11000$

図 11，12 図11は図 9 の機能端，図12は同時期の細胞機能端の一部拡大

細胞小突起 $(\mathrm{CP})$ が多数出現し，突起間に細胞膜彎入部 (IC) がみられる。 basement membrane は消失し， 隣接面や彎入部その他の細胞膜には, coated vesicle (CV) による pinocytosis が多く みられる。また象牙質基質表面における collagen 線維 (CO) が細胞の彎入部 (IC) 内に侵入して いる。細胞質内には微細 tube 状構造 (TS) の数が増し, 分泌顆粒 (SG) が観察される。また terminal bar (TB) が機能端からごくわずかながら後退している。図11では基質表層の collagen 線維 が減小するにともなってすでに amorphous material (AM) が出現している。 $\times 21000$ (図11), $\times 25000$ (図12)

図 13 エナメル質基質が形成されはじめた時期の内エナメル上皮

隣接面細胞膜には interdigitation が発達し，核より機能側細胞質に位置する Golgi area (GA) は 範囲が拡大し, 多数の大小様々の顆粒状構造物が観察される。 mitochondria (M) は terminal bar （TB）の基底側に局在している。エナメル質がまだ形成されてない部分の機能端細胞膜は凹凸を示し ているが，エナメル質の結晶（EC）が出現するにしたがって機能端細胞膜は平滑になっている。ま たエナメル質の結晶が出現する以前に，機能端細胞膜と象牙質との間に amorphous material (AM) が出現している。なお象牙質の結晶は電子染色によって溶失している。 $\times 10000$

図 14 図13の Golgi area の拡大

Golgi lamelle は長く, その両端や周辺に Golgi vesicle や coated vesicle (CV) が増加し, sER が発達してくるとともに, 分泌顆粒 $(\mathrm{SG})$ や大小様々の顆粒状構造物 $\left(\mathrm{L}_{1}, \mathrm{~L}_{2}\right)$ などの数が増してい る。 $\times 20000$

図 15 エナメル質基質形成初期の芽細胞の機能端の一部拡大

細胞膜彎入部 (IC)，あるいは隣接細胞間隙などの細胞膜外に多数の amorphous material (AM) が 出現し，幼若なリボン状のエナメル質の結晶（EC）が沈着しはじめている。機能端細胞質には微細 な tube 状構造物 (TS) のほか, 顆粒状構造物などが観察され, それらの間陌には非常に微細な線維 状構造物が観察される。 $\times 42000$

図 16 図15と同様エナメル質基質が形成されはじめた時期の細胞機能端 
terminal bar (TB) が機能端よりやや後退し， terminal web（TW）も発達しはじめている。 terminal bar より機能端細胞質には, 分泌顆粒 (SG) その他種々の顆粒状構造物が増加を示すととも に, 微細な tube 状構造物（TS）もかなり発達している。エナメル質基質形成前に，機能端細胞膜 外にすでに amorphous material (AM) が密に出現している。 $\times 14000$

図 17 図13 16の標本よりエナメル質基質形成がわずかに進行した時期のエナメル芽細胞 背丈が伸長し, Golgi area (GA) は, 核 (N) の機能側に近接しているが, その範囲が拡大されて いる。rER は増加しているが, その配列はいまだ不規則である。隣接面の細胞膜には interdigitation が発達し, terminal bar (TB) は機能端からはなれた位置に存在している。mitochondria (M) は terminal web (TW) の基底側に密集しているが, それらの一部は terminal web を越えて機能 端細胞質にも侵入している。また Golgi area や機能端細胞質などには大小さまざまな顆粒状構造物 $\left(\mathrm{L}_{1}, \mathrm{~L}_{2}\right)$ が観察される。×10000

図 18，19 図17と同時期の細胞の Golgi area の拡大

Golgi area では sER が発達し, 不規則な分枝もみられる。また sER が rER (黒矢印) や, Golgi lamelle (白矢印) と連絡する部分もみとめられる。Golgi lamelle は一層長くなり, Golgi vesicle, coated vesicle $(\mathrm{CV})$, 分泌顆粒 (SG) や L 2 顆粒のほか杆状体 (RS) などが観察される。 $\times 17000$ (図18)，×14000（図19）

図 20 図17と同時期の細胞機能端の拡大

terminal bar (TB) ならびに terminal web (TW) は発達を示し, terminal bar は機能端よりや や後退した位置となる。細胞膜彎入 (IC) や隣接細胞間隙 (ICS), およびその他の細胞膜外に amorphous material (AM) が密に観察される。機能端の細胞質内には微細線維状構造物や tube 状構造 物 (TS), free の ribosome のほか, 多数の分泌顆粒 (SG), その他の顆粒状構造物や杆状体などが みられる。×24000

図 21 図22, 23と同時期の細胞機能端拡大

細胞能機能端では, terminal web (TW) が発達し、それより機能端における細胞間隙 (ICS) が開大 するとともに, 細胞膜彎入 (IC) も多数観察される。また, それらの領域には amorphous material (AM) が密に観察され, 機能端細胞質には, 多数の分泌顆粒 (SG) や coated vesicle (CV), tube 状構造物 (TS) のほか, 顆粒状構造物も観察される。 $\times 23000$

図 22，23 図17〜20の標本よりさらにエナメル質基質形成が進んだ時期で，エナメル芽細胞の細胞長が最大 となった時期の標本を示したものである。

図22は細胞縦断像, 図23は横断に近い斜断像を示す。Golgi area (GA) は核 (N) の機能側からさ らに機能側細胞質のほぼ中央附近にまで抬大されている。隣接面には interdigitation をなす領域が 多く, 細胞間隙はほとんどみられない。機能端の細胞膜は平坦で, terminal bar (TB) および terminal web (TW) はともにもっとも発達した状態となっている。 mitochondria (M) は terminal web の基底側に局在し，長杆状のものが細胞の長軸方向に配列している。また rER も細胞の長軸. 方向に密に配列している。×6500（図22），×90000（図23）

図 24 図22, 23と同時期の芽細胞における Golgi area の拡大

不規則な状態に分枝した sER が多数観察され，分泌顆粒（SG）も多くみとめられる。また Golgi vesicle や coated vesicle $(\mathrm{CV})$ も同様に多く, $\mathrm{L}_{2}$ 顆粒その他 lysosome 様の顆粒状構造物も観察 される。 $\times 24000$

図 25，26 エナメル質基質形成期のエナメル芽細胞にみられる特殊な顆粒状構造物

不明瞭ながらも限界膜に囲まれた内部には，針状結晶様構造がほぼ放射状に配列している。図25では それらの密度が比較的低く, 図26のものではかなり密度が高くなっている。×30000（図25，26）

図 27，28 エナメル質基質形成末期のエナメル芽細胞で，図27は綎断像，図28は斜断像を示したもの。 芽細胞はエナメル質基質形成期と同様背が高く, 細胞の形態は基本的に図22の時期と変化はみられな い。しかし, 機能側の terminal bar (TB) は順次機能端に向かって移動し, terminal web も不明 瞭となっている。機能端細胞膜は平滑で細胞膜彎入 (IC) の数も減少している。Golgi area (GA) は 核 (N) の機能側近傍に位置する。mitochondria (M) は matrix が明調で, しかも形のやや大き なものと漸次推移し，それにともない局在性が失なわれていく。また rER も徐々に数を減じ, 配列! も不規則になる。分泌顆粒は徐々に消失するが, L 2 顆粒がわずかに残存するほか Golgi are をはじ め, 細胞質全域に $\mathrm{Lm}$ 顆粒が順次増加している。×6000（図27），×8000（図28）

図 29，30 図27，28と同時期の細胞における Golgi area

図29の細胞では Golgi area (GA) に分泌顆粒 (SG) や $\mathrm{L}_{2}$ 顆粒がみとめられる。しかし図30の細 胞では, Golgi area がやや縮少し, 分泌顆粒がみられず, Lm 顆粒などが増加を示している。 $\times 24000($ 図29,30)

図 31 図27,28のエナメル質基質形成末期のエナメル芽細胞機能端を示したもの mitochondria は matrix の明調なものに変わり, 局在性は消失している。 terminal bar（TB）は 
機能端近くにまで移動し，発育がやや低下するとともに terminal web が不明瞭となり, mitochondria の分布が機能端に近ついている。しかし機能端細胞質には分泌顆粒 (SG) や顆粒状構造物 ( $\mathrm{L}_{2}$, Lm 等)，杆状体 (RS) あるいは coated vesicle (CV) などがまだ観察され，また微細 tube 状構 造物 (TS) もまだ観察されるが，その規模は減少している。しかし機能端細胞膜は平滑で，細胞膜 彎入 (IC) の数も減じているが, 細胞質深部への彎入度が増し, それらの部分には amorphous material (AM) が観察される。 $\times 18000$ 